RICHARDSON VIANA AGRA

APLICAÇÃO DO MODELO PDCA 90-10 NA GESTÃO DE ATIVOS DE MINAS A CÉU ABERTO

Dissertação apresentada à Escola Politécnica da Universidade de São Paulo para a obtenção do título de Mestre em Engenharia. 
RICHARDSON VIANA AGRA

\section{APLICAÇÃO DO MODELO PDCA 90-10 NA GESTÃO DE ATIVOS DE MINAS A CÉU ABERTO}

Dissertação apresentada à Escola Politécnica da Universidade de São Paulo para a obtenção do título de Mestre em Engenharia.

Área de Concentração:

Engenharia Mineral

Orientador:

Prof. Dr. Giorgio De Tomi 
Este exemplar foi revisado e corrigido em relação à versão original, sob responsabilidade única do autor e com a anuência de seu orientador.

São Paulo, 06 de janeiro de 2014.

Assinatura do autor

Assinatura do orientador

FICHA CATALOGRÁFICA

Agra, Richardson Viana

Aplicação do modelo PDCA 90-10 na gestão de ativos de minas a céu aberto / R.V. Agra. -- São Paulo, 2014.

p.

Dissertação (Mestrado) - Escola Politécnica da Universidade de São Paulo. Departamento de Engenharia de Minas e de Petróleo.

1.Escavação a céu aberto 2.Gestão por processos 3.Empreendimentos mineiros I.Universidade de São Paulo. Escola Politécnica. Departamento de Engenharia de Minas e de Petróleo II.t. 


\section{AGRADECIMENTOS}

À Coordenação de Aperfeiçoamento de Pessoal de Nível Superior - CAPES, pela concessão de bolsa de estudo para o desenvolvimento das atividades desta pesquisa.

O autor agradece 0 apoio da FAPESP por meio do processo № 2010/51287-0, Fundação de Amparo à Pesquisa do Estado de São Paulo (FAPESP).

À empresa VALE, parceira do projeto de pesquisa, pela disponibilização de todas as informações necessárias aos estudos realizados, bem como pessoal de suporte para o acompanhamento das atividades.

Ao Prof. Dr. Ricardo Cabral de Azevedo, pela contribuição na estruturação e formalização do conteúdo deste trabalho.

Ao Eng. de Minas Afonso Heraldo Petta pelo compartilhamento de experiências práticas e todas as demais contribuições ao longo da realização deste trabalho.

Ao Geólogo Alexandre Orlandi Passos que, com sua larga experiência no setor de mineração, ajudou a esclarecer fatores de grande relevância para a gestão racional de mina. 


\section{DECLARAÇÃO DE RESPONSABILIDADE}

As opiniões, hipóteses e conclusões ou recomendações expressas neste material são de responsabilidade do autor e não necessariamente refletem a visão da FAPESP. 
Não importa o que você seja, quem você seja ou o que deseja. Na vida, a ousadia em ser diferente reflete na sua personalidade, no seu caráter, naquilo que você é. E é assim que as pessoas lembrarão de você um dia. 


\section{RESUMO}

A crescente demanda mundial por bens de consumo exige que as empresas de mineração busquem continuamente níveis de produção cada vez mais elevados. Devido a essa necessidade, a cada momento são incorporados às empresas, novos equipamentos e processos, de modo a gerar melhorias no seu processo produtivo dentro dos padrões específicos de mercado. Desta forma, alocar todos estes recursos de forma racional vem se tornando uma tarefa cada vez mais complexa, a qual exige grande esforço das equipes de planejamento de projetos de minas. Nesse contexto, este trabalho propõe a incorporação da ideia da gestão racional de ativos nas operações de mina, levando em conta os diferentes métodos atuais de lavra a céu aberto bem como aqueles que surgem como tendências futuras para as próximas décadas. Para tanto, é apresentada inicialmente a pesquisa bibliográfica realizada, destacando os pontos de relevância dos métodos atuais e futuros de lavra a céu aberto e abordando os aspectos referentes à gestão operacional de mina. Em seguida, são apresentados os conceitos base do PDCA 90-10, um modelo conceitual de gestão de ativos de minas a céu aberto voltado para as áreas operacionais e táticas da mineração. A seguir, é apresentada uma proposta de metodologia baseada no modelo PDCA 90-10 para o processo decisório da programação de produção de uma mina a céu aberto em operação no Brasil. Finalmente, são apresentados os resultados e as conclusões do trabalho, com destaque para a sugestão da introdução dos conceitos do PDCA 90-10 ao modelo de gestão operacional já existente na mina, com a proposta do seu aprimoramento para a solução dos desafios da integração entre as áreas de planejamento e operação.

Palavras-Chave: Gestão de operações; modelo PDCA 90-10; mineração. 


\begin{abstract}
The growing worldwide demand for consumer goods requires that the mining companies continuously seek higher levels of production. Because of this need, new equipments and processes are incorporated by the companies. The main objective of these technologies is to provide enhancements for their productive processes within the specific market standards. This way, allocating all these resources according to a rational manner is becoming an increasingly complex task. This task requires a great effort by the planning teams of mine projects. In this context, this work proposes to incorporate the idea of rational assets management in mine operations. For this, it is necessary take into account the different existing mining methods to open pit mines as well as those seem to be the tendencies to next decades. To achieve this, initially a literature research is presented. This literature research highlights the most relevant issues related to current and future methods for open pit mining, regarding the aspects related to operational mine management. After this, the concepts of PDCA 90-10 are presented as a conceptual model of assets management for open pit mines focusing on the mine tactical and operational areas. In sequence, a methodology proposal based on PDCA 90-10 model is presented to help on the decision making process of the production scheduling for an open pit mine operating in Brazil. Finally, the work results and conclusions are presented with emphasis on the suggestion of introduction of the PDCA 90-10 concepts to the existing operational management model. The purpose is to improve this model to solve integration challenges between planning and operational areas.
\end{abstract}

Key-Words: Management of operations; PDCA 90-10 model; mining. 


\section{LISTA DE ILUSTRAÇÕES}

Figura 01 - Mina de Diavik, localizada no Canadá. Funciona desde 2003 e produz 8 milhões de quilates de diamantes ou aproximadamente $1.600 \mathrm{~kg}$ dediamantes por ano ................................................................

Figura 02 - Caminhão fora-de-estrada, modelo T 282B, produzido pela fabricante Liebherr, com capacidade para 400 toneladas de carga .8

Figura 03 - Escavadora sobre esteiras, modelo R 9800, produzida pela fabricante Liebherr, com caçamba de $42 \mathrm{~m}^{3}$ de capacidade 8

Figura 04 - Lavra ornamental (detalhe para a altura e verticalidade das faces) .....11

Figura 05 - Escavadora do tipo "Bucket Wheel", utilizada no método de "Lavra em Tiras" 13

Figura 06 - Equipamento utilizado no método "Auger Mining": trado mecânico operado a partir da superfície para a recuperação de carvão 16

Figura 07 - Equipamento utilizado no método "Highwall Mining": minerador contínuo operado a partir da superfície para a recuperação de carvão 16

Figura 08 - Arranjo de correias coletoras transportando materiais para pilhas de estoque distintas 19

Figura 09 - Vista de uma correia de bancada da mina de Alegria, da VALE "..... 20

Figura 10 - Correia Transportadora de Longa Distância utilizada na mina Pierina, Peru 
Figura 11 - Vista da Mina Pierina, Cordilheira dos Andes, Peru 21

Figura 12 - llustração resumida do arranjo operacional de lavra por correias transportadoras .23

Figura 13 - Britagem móvel autoalimentada (minerador contínuo) 26

Figura 14 - Britagem móvel alimentada por unidades carregadoras .27

Figura 15 - Unidade de britagem semimóvel 28

Figura 16 - Arranjo entre os componentes básicos de um sistema autônomo de mineração 35

Figura 17 - Arquitetura simplificada de sistemas de automação complexos .36

Figura 18 - Caminhão 930E - Komatsu 40

Figura 19 - Sistema de automação de transporte da Komatsu 40

Figura 20 - Caminhão 793F - Caterpillar 41

Figura 21 - Estrutura organizacional de uma mineradora. Neste caso, com ênfase à área objeto de estudo deste trabalho: a área de gestão de ativos físicos

Figura 22 - Mecanismos de interação entre as unidades funcionais numa mina ..49

Figura 23 - Organograma organizacional para a área de equipamentos de lavra .53

Figura 24 - Gráfico dos custos de equipamentos 59 
Figura 25 - Etapas do ciclo PDCA 63

Figura 26 - Metodologia para realização do trabalho 66

Figura 27 - Esquema geral de um modelo 90-10 de gestão operacional de mina e manutenção de equipamentos de lavra 69

Figura 28 - Mapeamento estratégico de processos, com base na adaptação da metodologia de Marcelli (2000) 72

Figura 29 - Princípios básicos da qualidade na gestão operacional de mina .74

Figura 30 - Cidade de Canaã dos Carajás - PA 75

Figura 31 - Vista panorâmica de uma das cavas da unidade Sossego .76

Figura 32 - Metodologia de execução do Line Up para o controle e gestão das operações 79

Figura 33 - Estrutura de hierarquia do Line Up 81

Figura 34 - Vista interna da unidade de manutenção de equipamentos da mina de Sossego 82

Figura 35 - Line Up 90-10, de acordo com suas premissas e resultados gerados 88 


\section{SUMÁRIO}

1. INTRODUÇÃO Erro! Indicador não definido.

1.1. Motivação .2

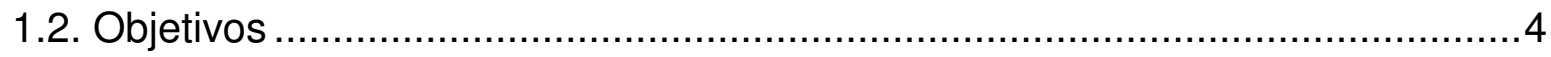

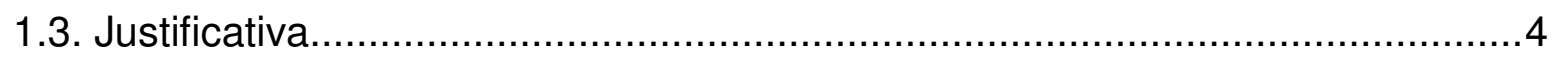

2. REVISÃO BIBLIOGRÁFICA..........................................................................6

2.1. Métodos Convencionais de Lavra a Céu Aberto .....................................6

2.1.1. Lavra em Cava...............................................................................

2.1.2. Lavra em Pedreiras......................................................................... 10

2.1.3. Lavra em Tiras ......................................................................... 12

2.1.4. Lavra de Recuperação Subsuperficial ............................................... 15

2.2. Lavra a Céu Aberto por Sistemas de Correias ........................................18

2.2.1. Transportador de Correias Coletoras................................................. 18

2.2.2. Transportador de Correias de Bancada........................................... 19

2.2.3. Transportador de Correias de Longa Distância ....................................20

2.2.4. Aspectos Operacionais dos Transportadores de Correias......................22

2.3. Lavra por Britagem "In Pit" Autopropelida .......................................... 25

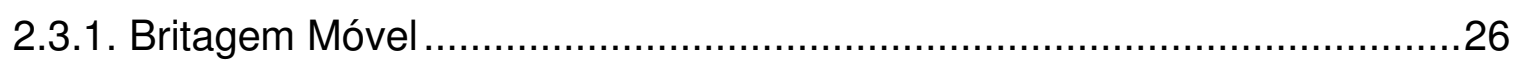

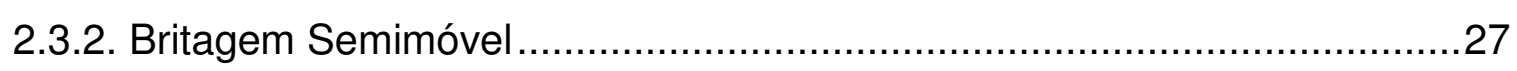

2.3.3. Aspectos Operacionais da Britagem “In Pit" Autopropelida ......................28

2.4. Equipamentos Autônomos na Mineração ................................................ 33

2.4.1. Entendendo os Sistemas Autônomos ................................................ 34

2.4.2. Benefícios da Automação na Mineração ............................................ 37

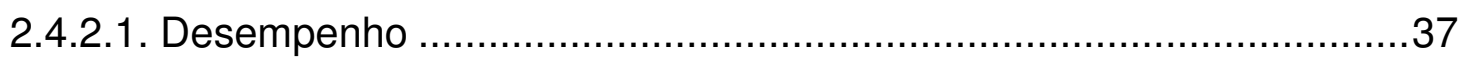

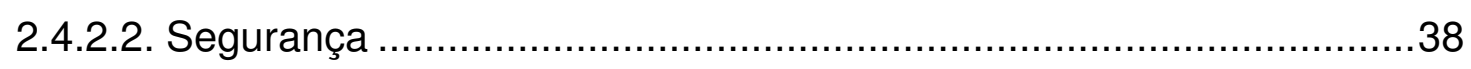

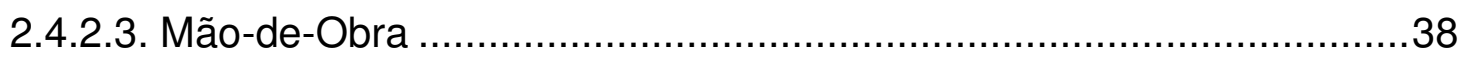

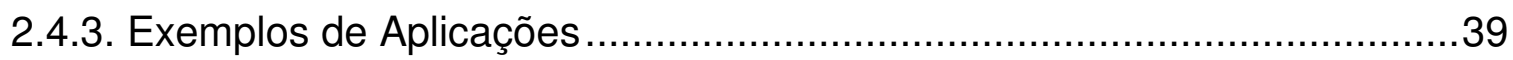

2.4.4. Desafios de Implementação de Sistemas Autônomos ............................ 41

2.4.5. Perspectivas para a Automação na Mineração .................................... 42 
2.5. Gestão Operacional e Manutenção de Ativos Físicos..................................44

2.5.1. Áreas Funcionais da Mina e Suas Interações......................................46

2.5.2. Área de Equipamentos de Lavra................................................... 51

2.5.3. Gestão de Ativos em Empresas de Mineração .....................................53

2.5.3.1. Atendimento às Frentes de Lavra .............................................55

2.5.3.2. Especificações dos Equipamentos de Lavra ..................................56

2.5.3.3. Análise Econômica e Ponto de Substituição de Equipamentos..........58

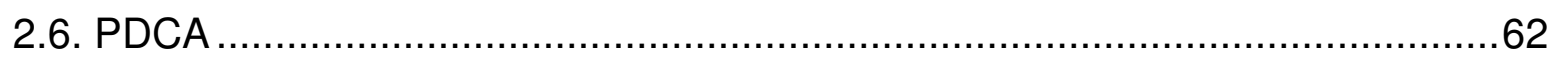

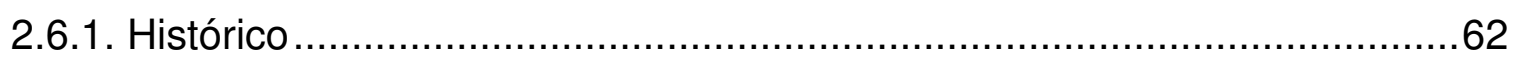

2.6.2. Definições do PDCA .................................................................... 63

2.6.3. PDCA Como Ferramenta de Melhoria Contínua...................................64

3. MATERIAIS E MÉTODOS ...........................................................................66

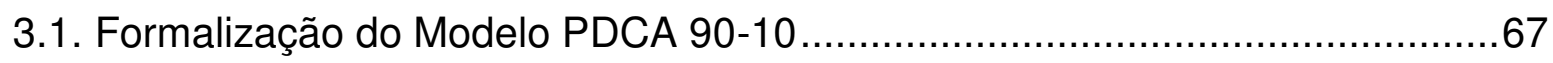

3.1.1. PDCA 90-10 Como Modelo de Gestão Estratégica de Mina ...................69

3.1.2. Importância da Qualidade no PDCA 90-10 .......................................73

3.1.3. PDCA 90-10 Aplicado a Novos Cenários Operacionais..........................75

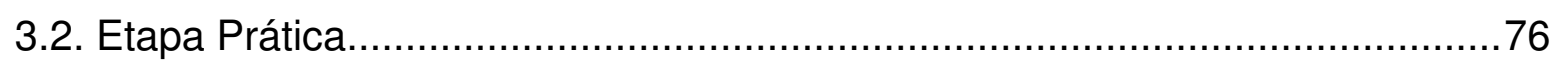

3.2.1. Alinhamento Inicial sobre a Linha de Pesquisa ................................... 76

3.2.2. Diagnóstico do Cenário Operacional da Mina de Sossego .......................77

3.2.3. Formalização do Procedimento Atual de Gestão Operacional na Mina de Sossego ......................................................................................... 78

3.2.4. Identificação dos Principais KPI's das Operações................................. 82

3.2.5. Propostas de Melhorias com Base nos Conceitos do PDCA 90-10.........83

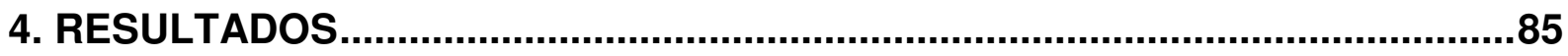

5. CONCLUSÕES ..........................................................................................93

6. REFERÊNCIAS BIBLIOGRÁFICAS ...........................................................94 


\section{INTRODUÇÃO}

No cenário global atual, a mineração atravessa um período de significativas mudanças nos seus mais diversos aspectos. A cada momento, a demanda por materiais cresce, demanda esta que deve ser suprida dentro de restrições cada vez maiores quanto à utilização dos recursos disponíveis. Nesse novo cenário que surge para a mineração, especificamente para a mineração a céu aberto, objeto de estudo deste trabalho, as metodologias convencionais de lavra começam apresentar tendências de evoluções operacionais, restando às empresas buscar novas soluções para suas atividades.

Desta forma, surge a necessidade de introdução de novos conceitos de lavra de forma alinhada às tendências futuras de evolução para as operações, tais como, por exemplo, operações com soluções tipo "driverless" ${ }^{1}$ e "truckless" ${ }^{2}$. Num cenário operacional como esse, a mineração necessitará de uma nova geração de ferramentas de gestão de mina que permita às equipes de planejamento uma tomada de decisões confiável e eficaz para todas as operações de lavra.

Especificamente na mineração a céu aberto, foco deste trabalho, um dos principais desafios a serem enfrentados pelas equipes de planejamento será a definição e aplicação dos conceitos e mecanismos de gestão corporativa para os novos sistemas de atividades da mina. Nesse contexto, segundo Whittle (2004), o desafio para a conceituação dos processos e das ferramentas para a gestão de lavra passa pela necessidade de aprimorar o nível de visibilidade, padronização e integração de todos os ativos da mina. Essa abordagem é comumente associada à expressão "asset optimization" ou "otimização de ativos" da empresa. Mesmo que não se trate estritamente de um processo de otimização absoluta, essa abordagem possui um caráter otimizante porque busca em todo momento a maximização da utilização dos

1 Especificamente, as soluções "driverless" correspondem aos arranjos de lavra onde o transporte de materiais na mina é executado por caminhões sem operadores embarcados, com operação por controle remoto orientada por GPS, como descrito, por exemplo, em Zoschke (2002), Albanese (2008) e Jamasmie (2009).

2 As soluções "truckless" correspondem aos arranjos de lavra onde o transporte de materiais é executado por correias transportadoras a partir de um britador móvel localizado na cava, de acordo, por exemplo, com Zimmermann e kruze (2006), Copans (2007) e Lopes (2010). 
ativos. Neste trabalho, o termo "ativo" faz referência aos ativos físicos das operações de lavra, ou seja, aos equipamentos. Por exemplo: perfuratrizes, unidades carregadoras, caminhões, dentre outros.

Levando em consideração os aspectos citados, este trabalho contempla inicialmente uma pesquisa bibliográfica descrevendo os principais métodos de lavra utilizados em minas a céu aberto atualmente e suas linhas de evolução para as próximas décadas, com o objetivo principal de identificar os pontos críticos para a tomada de decisões operacionais nas atividades realizadas. A seguir, apresenta-se um estudo sobre os aspectos de relevância na gestão de ativos nas empresas, de modo que os resultados apresentados possam indicar os pontos críticos no processo de tomada de decisões pelas equipes de planejamento nas companhias de mineração. Com base em pesquisas realizadas, um dos pontos críticos identificados nas empresas de mineração diz respeito à integração entre as áreas de planejamento e operação. Desta forma, o foco do estudo se concentrou na investigação de soluções para esse desafio, com a proposta de incorporação do modelo PDCA 90-10 no processo de integração entre planejamento e operação. Neste sentido, foram realizados testes desta proposta numa mina a céu aberto em operação no Brasil, com o objetivo avaliar o PDCA 90-10 como um modelo estratégico de gestão de mina que integra as áreas de planejamento e operação, modelo este que possa ser replicado para outros cenários operacionais de minas, com eventuais ajustes em virtude das particularidades de cada operação.

\subsection{Motivação}

Em países que atravessam um período de desenvolvimento acelerado, com destaque para o Brasil no cenário atual, a mineração tem um papel de grande relevância econômica, o que faz necessário a aplicação alinhada de esforços no sentido de dar ao país a capacidade de geração sustentável de riquezas, de modo que seja assegurada a sua competitividade e representatividade em nível global. 
Num panorama atual, onde a demanda por bens de consumo cresce continuamente, os preços das commodities ${ }^{3}$ minerais têm alcançado patamares cada vez mais elevados, visto a limitação da capacidade de produção das empresas, frente à crescente demanda imposta pelo mercado.

Nesse cenário de oportunidades de negócios, as companhias mineradoras fazem altos investimentos tanto no desenvolvimento e implantação de novos projetos quanto na reestruturação e ampliação de projetos já existentes. Nesse contexto, podem ser citados como exemplos os investimentos de US $\$ 1,8$ bilhão realizados pela mineração Anglo American para a implantação do projeto de níquel no município de Barro Alto - GO e a ampliação da produção de sulfeto de cobre e ouro, pela Mineração Maracá, do grupo canadense Yamana, no município de Alto Horizonte - GO. Ainda, podem ser citados outros dois grandes projetos focados na exploração de níquel: o primeiro é resultado de um investimento de US\$ 450 milhões realizado no Estado da Bahia pela empresa Mirabela Mineração do Brasil Ltda.; o segundo corresponde ao Projeto Onça Puma, da VALE, localizado no Estado do Pará, cujo investimento é da ordem de US $\$ 2,2$ bilhões, segundo informações das próprias companhias.

Mesmo nesse panorama de grandes oportunidades, com condições favoráveis de mercado e investimentos, deve ficar claro que o sucesso ou o fracasso de um empreendimento mineral estará diretamente ligado à gestão de cada projeto. Nesse contexto, Sachs (2009) define que todas as etapas envolvidas na produção e gestão do negócio de uma mineradora poderão ser modeladas e gerenciadas de forma mais eficiente, quando for possível visualizar todas as informações do negócio, desde a geologia até os estoques de produto final, desde as reservas minerais até a gestão de resultados.

Commodities são produtos produzidos em grande escala, cuja comercialização se dá em nível global por meio da negociação em bolsas de valores. Existem quatro tipos de commodities: agrícolas, minerais, financeiras e ambientais. 


\subsection{Objetivos}

Os objetivos deste trabalho são:

- Estudar os aspectos referentes à gestão de minas a céu aberto, com ênfase na gestão das operações e dos equipamentos de lavra, tendo como objetivo principal a identificação de pontos de oportunidades de ganhos operacionais;

- Definir os conceitos de um modelo estratégico de gestão de mina, o PDCA 90-10, que funcione como uma ferramenta direcionada para as áreas funcionais e táticas da mineração, dentro de um ciclo PDCA, cuja finalidade seja conduzir as equipes de forma alinhada aos objetivos globais das empresas;

- Aplicar o modelo conceitual de gestão proposto numa mina em operação no Brasil, avaliar e analisar os resultados da aplicação, e identificar novas oportunidades de aplicação para outras minas e diferentes cenários operacionais de lavra.

\subsection{Justificativa}

De acordo com Nader e Sachs (2008), o principal foco de um sistema empresarial do segmento da mineração deve ser manter a alta utilização dos equipamentos, por meio de uma gestão efetiva da manutenção e da utilização da capacidade instalada ${ }^{4}$. Desta forma, com o objetivo de garantir o melhor desempenho das operações da mina, devem ser eliminadas as perdas de tempo e a ociosidade dos equipamentos ao longo das operações.

$\mathrm{Na}$ definição dos equipamentos a serem utilizados nas operações de lavra, devem ser levadas em consideração todas as variáveis envolvidas: volume de produção, distâncias de transporte, tipo de material a ser transportado, dentre outros. Além

4 A capacidade instalada representa o potencial de produção ou volume máximo de produção que uma determinada empresa, unidade, departamento, ou seção, consegue atingir durante certo período de tempo, considerando todos os recursos que tem disponíveis. 
disso, estes equipamentos (e equipes) devem ser definidos de forma que toda a operação ocorra de forma integrada e sincronizada, visando, por exemplo, evitar situações como a formação de filas, ociosidade, indisponibilidade física, dentre outros. Neste sentido, grande parte dos problemas observados nas operações de minas está relacionada aos modelos de gestão utilizados que, em sua maioria, não são adequados ao cenário operacional no qual estão inseridos e, mesmo que estejam, não são obedecidos plenamente pelas equipes.

Portanto, uma vez identificadas as lacunas existentes nos modelos de gestão de lavra (seja ela por meio de métodos convencionais ou seguindo as tendências de evolução) adotadas por grande parte das companhias de mineração, a introdução de sistemas de gestão deverá apresentar como proposta a solução para os problemas relacionados às atividades da mina, de forma a integrar todas as atividades operacionais, com objetivo de aumentar a produtividade, qualidade e flexibilidade de produção, de forma alinhada com a política estratégica da empresa. 


\section{REVISÃO BIBLIOGRÁFICA}

\subsection{Métodos Convencionais de Lavra a Céu Aberto}

O termo "mineração a céu aberto" faz referência a todos os métodos de extração de minérios (ou rochas) cujas operações de lavra sejam realizadas em superfície. Este tipo de mineração é utilizado quando os depósitos minerais de interesse se encontram próximos ou relativamente próximos à superfície, ou seja, quando a camada de cobertura é pouco espessa ou não consolidada, de modo que o desenvolvimento de operações subterrâneas seja inviável economicamente e/ou operacionalmente.

$\mathrm{Na}$ mineração a céu aberto existem muitos métodos para a lavra dos depósitos minerais de interesse, métodos estes agrupados em duas categorias: (i) métodos mecânicos de lavra a céu aberto; (ii) métodos hidráulicos de lavra a céu aberto. No caso específico deste trabalho, o foco dos estudos realizados diz respeito apenas aos métodos mecânicos de lavra a céu aberto.

De acordo com Hartman (2002), os métodos mecânicos de lavra a céu aberto são aqueles nos quais o minério, camada de carvão ou simplesmente a rocha são extraídos por meio de operações realizadas e/ou controladas na superfície. Neste caso, existem quatro métodos mecânicos de lavra a céu aberto: Lavra em Cava, Lavra de Pedreiras, Lavra em Tiras e Lavra de Recuperação Subsuperficial ${ }^{5}$.

Novamente, segundo Hartman (2002), estes métodos são responsáveis por mais de 90\% da produção mineral a céu aberto nos Estados Unidos e são também os responsáveis pelos maiores volumes de produção de carvão mineral.

5 O termo "subsuperficial" faz referência à localização do material a ser recuperado, que pode ser, por exemplo, carvão. Nesse caso, uma vez que o controle do equipamento utilizado se dá a partir da superfície, este método é considerado como um método de extração mecânico a céu aberto. 


\subsubsection{Lavra em Cava}

Este método de mineração a céu aberto pode ser aplicado ao aproveitamento da maioria dos corpos minerais localizados próximos à superfície, cuja lavra ocorre por meio de uma ou mais bancadas horizontais, que podem variar de nove a 30 metros de altura [Hartman (2002)]. Neste caso, o desenvolvimento da lavra em bancadas permite o controle da profundidade dos desmontes realizados e do ângulo dos taludes, fatores estes críticos para o controle dos riscos relacionados à estabilidade das faces dos taludes.

A Figura 01 mostra um exemplo de aplicação do método de "Lavra em Cava".

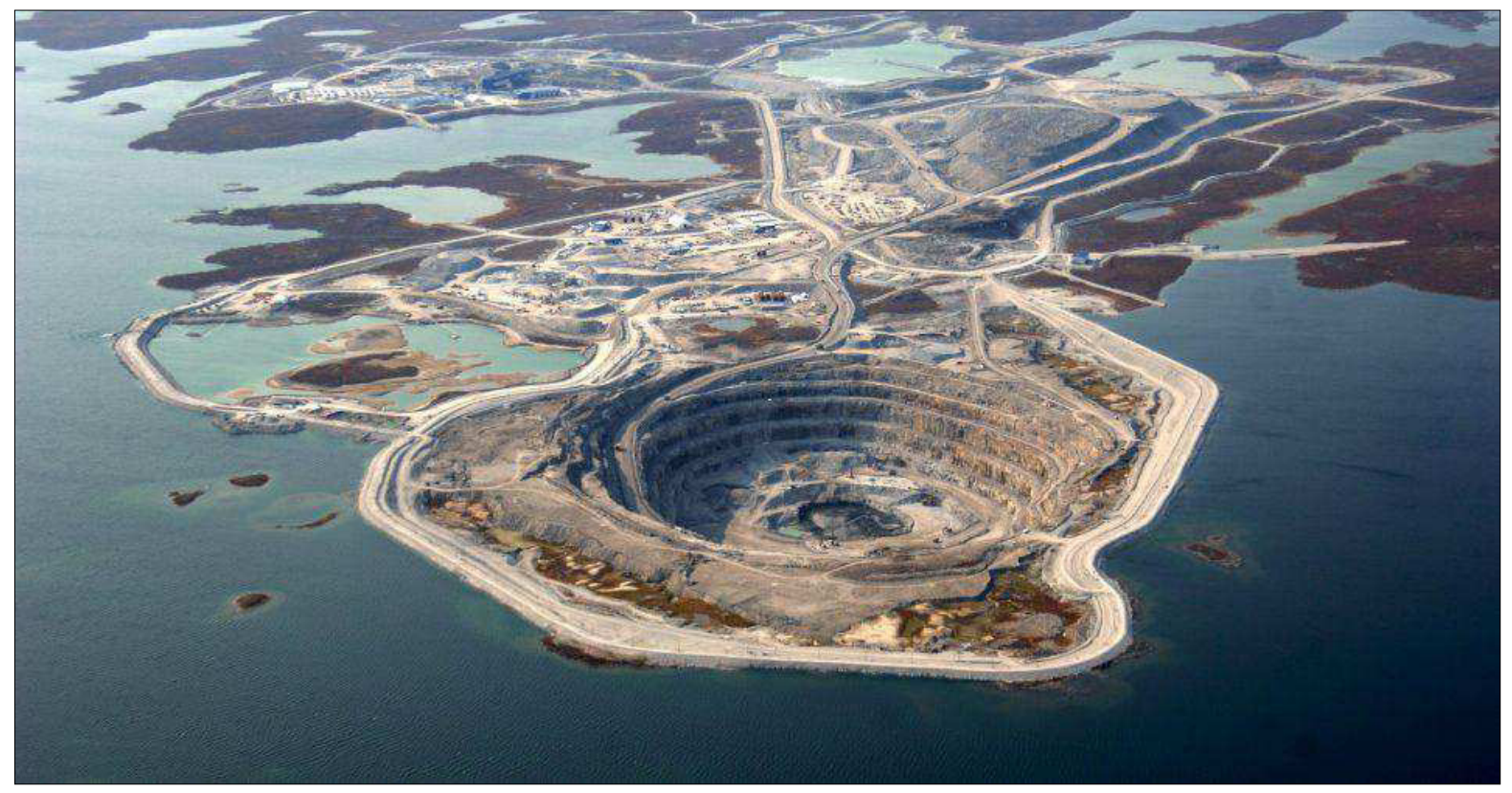

Figura 01 - Mina de Diavik, localizada no Canadá. Funciona desde 2003 e produz 8 milhões de quilates de diamantes ou aproximadamente $1.600 \mathrm{~kg}$ de diamantes por ano

(Fonte: http://www.gran-angular.net/los-7-hoyos-terrestres-mas-impresionantes/2007/09/13/)

Ainda, segundo Hartman (2002), o método de "Lavra em Cava" apresenta alta razão de produção, correspondendo a mais de $60 \%$ do total da produção dos métodos mecânicos de lavra a céu aberto. A movimentação de grandes volumes de materiais permite uma alta mecanização das operações, utilizando, na maioria dos casos, equipamentos de grande porte nas operações de lavra, conforme pode ser observado nas Figuras 02 e 03. 


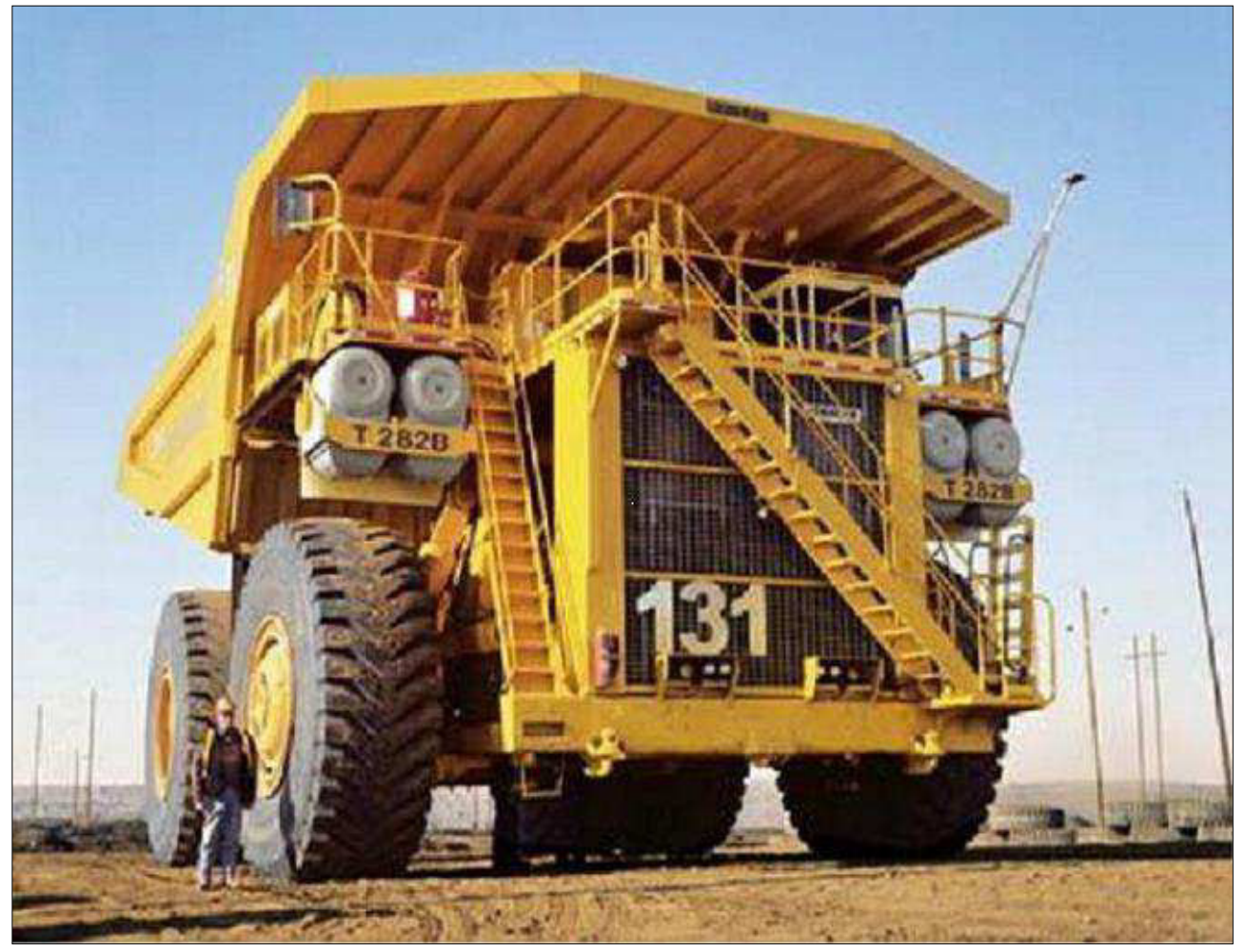

Figura 02 - Caminhão fora-de-estrada, modelo T 282B, produzido pela fabricante Liebherr, com capacidade para 400 toneladas de carga

(Fonte: http://bocaberta.org/2009/02/caminhoes-gigantes-os-maiores-do-mundo.html)

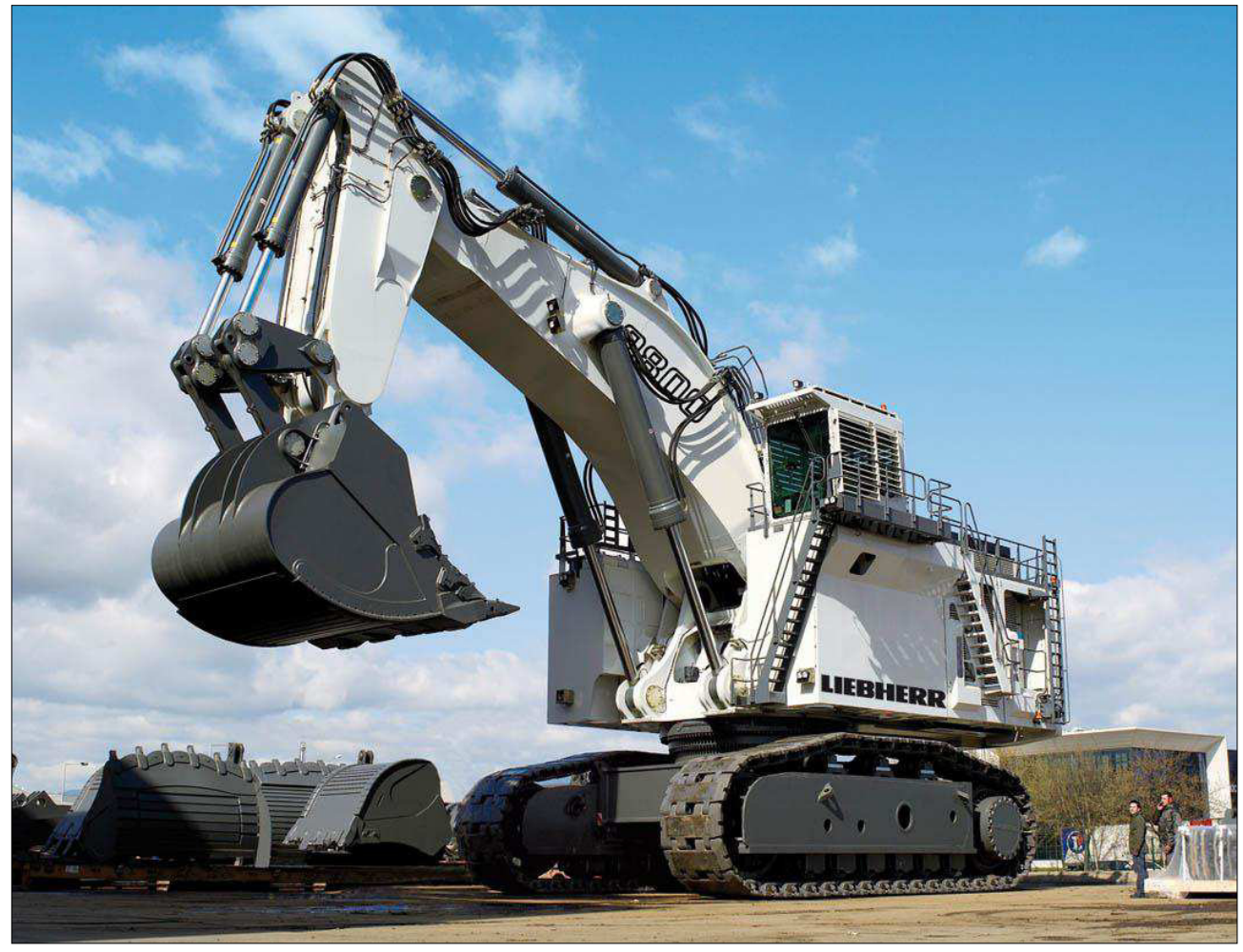

Figura 03 - Escavadora sobre esteiras, modelo R 9800, produzida pela fabricante Liebherr, com caçamba de $42 \mathrm{~m}^{3}$ de capacidade

(Fonte: http://goawaygarage.blogspot.com.br/2010/04/liebherr-r-9800.html) 
A seguir, são listadas as principais vantagens e desvantagens da utilização do método "Open Pit Mining", de acordo com informações discutidas em Pfleider (1973), Crawford and Hustrulid (1979) e Hustrulid e Kuchta (1995).

\section{(A) Vantagens}

- Alta produtividade;

- Menos custo operacional;

- Alta razão de produção;

- Não requer a utilização de mão-de-obra altamente qualificada nas operações;

- Flexibilidade operacional;

- Menor custo no desmonte;

- Desenvolvimento simples dos acessos;

- Pouco suporte requerido para a estabilização de taludes;

- Boa recuperação e diluição moderada;

- Riscos moderados em relação à saúde e segurança dos trabalhos.

(B) Desvantagens

- Limitação de profundidade (em torno de 300 metros);

- Relação estéril/minério limitada (devido fatores econômicos);

- Necessidade de alto capital de investimento na aquisição de equipamentos;

- Elevada exigência de recuperação ambiental;

- Necessidade de equipamentos de grande porte para viabilizar as operações;

- Passível às intempéries climáticas; 
- Necessidade de sistemas de bombeamento e drenagem, fatores críticos para a estabilidade dos taludes;

- Definição de uma área para disposição de rejeitos, área esta que deve ser mantida sob controle permanente;

- Após a lavra, devem ser anulados os riscos de poluição e de segurança em toda a área de atividades da mina;

- Necessidade de um plano de fechamento de mina.

\subsubsection{Lavra em Pedreiras}

Este método de lavra a céu aberto pode produzir blocos de rocha com formatos regulares e tamanhos definidos, para lavra de rochas ornamentais, ou simplesmente materiais agregados ${ }^{6}$, extraídos para a construção civil, por exemplo. Na lavra de rochas ornamentais é comum serem encontrados taludes semiverticais com alturas de até 300 metros. Isto pode ser justificado pela competência geomecânica dos maciços rochosos onde são realizados os trabalhos de extração. Estes tipos de rocha costumam ser utilizados na construção de monumentos, áreas decorativas em edifícios, pisos e outras aplicações mais específicas.

A Figura 04 mostra o exemplo de uma lavra em pedreiras (lavra de rochas ornamentais ${ }^{7}$ ).

6 A lavra de materiais agregados ocorre, em sua grande maioria, em cavas a céu aberto, caracterizando o método de lavra em cava. Desta forma, neste trabalho, considera lavra em pedreiras os casos de extração de rochas ornamentais.

7 Diferentemente das pedreiras tradicionais (para produção de agregados, por exemplo), onde os materiais são extraídos por meio da utilização de explosivos e classificados de acordo com padrões de granulometria (geralmente) do produto, o ciclo de operações em pedreiras de rochas ornamentais envolve: (i) extração não destrutiva de blocos de rocha de tamanhos préestabelecidos; (ii) beneficiamento primário, por meio de teares de serragem; (iii) beneficiamento secundário, por meio de polimento até a obtenção do produto finalizado. 


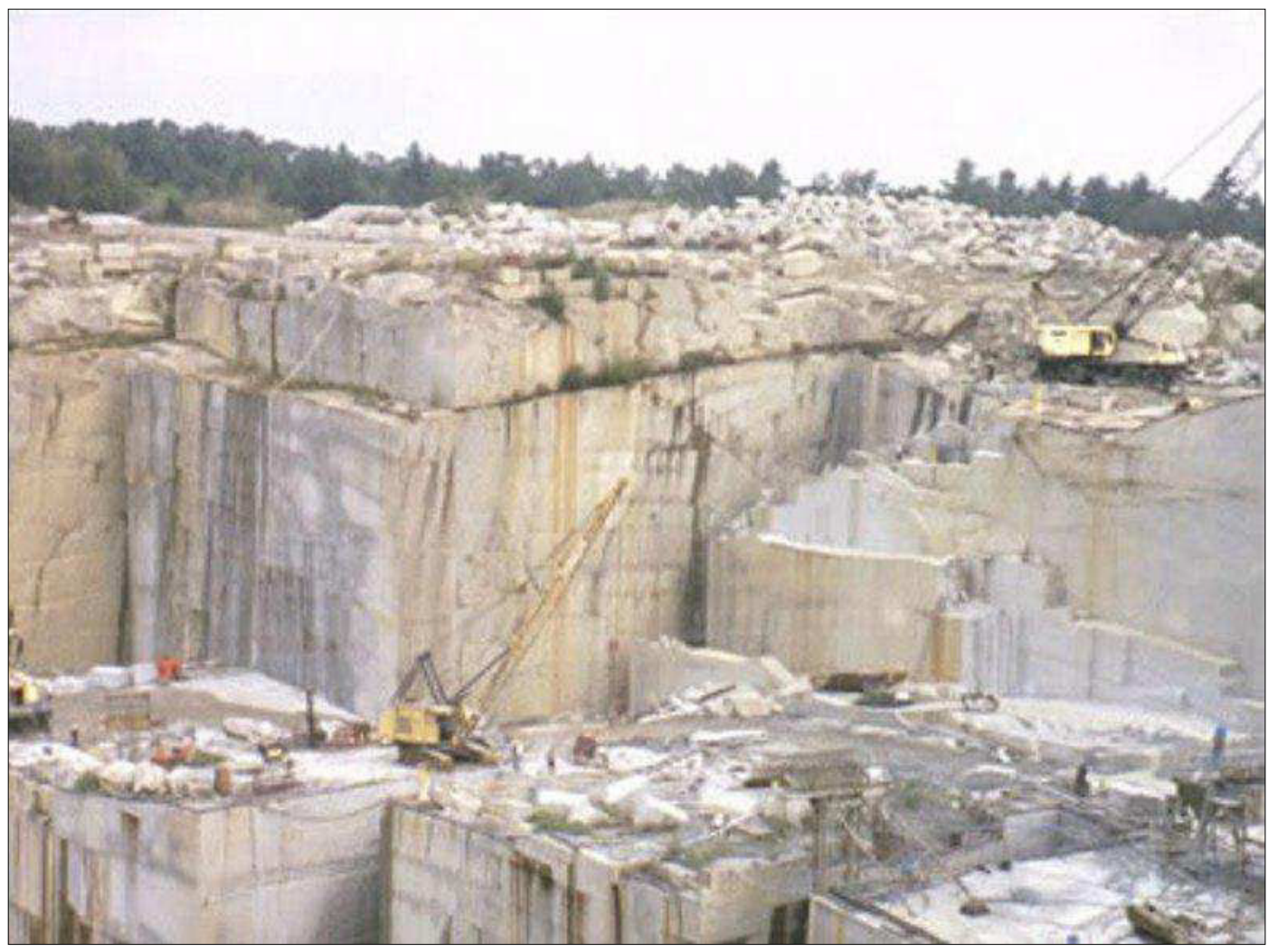

Figura 04 - Lavra ornamental (detalhe para a altura e verticalidade das faces) (Fonte: http://upload.wikimedia.org/wikipedia/commons/2/23/Dimension_Stone_QuarryUSGOV.jpg)

A seguir, são apresentadas as principais vantagens e desvantagens deste método de lavra, de acordo com Morrison e Russel (1973) e Power (1975).

\section{(A) Vantagens}

- Baixo custo de capital, devido à utilização de mecanização relativamente pequena;

- Pode ser adequado para pequenos depósitos;

- Facilidade de acesso para movimentação do material da lavra e suprimentos para as atividades;

- Bancadas de lavra estáveis, devido a condições geotécnicas favoráveis do maciço rochoso;

- Utilização de pouco ou nenhum sistema de suporte; 
- Alta seletividade;

- Boas condições de segurança no trabalho, visto que há poucos riscos de instabilidade.

(B) Desvantagens

- Limitação de profundidade (em torno de 300 metros);

- Baixa produtividade;

- Alto custo de lavra em função da baixa produtividade;

- Necessidade de utilização de trabalho especializado;

- Pouca ou nenhuma flexibilidade operacional, uma vez que o plano de mina não pode ser modificado com facilidade (para o caso da lavra de rochas ornamentais);

- Mecanização limitada.

\subsubsection{Lavra em Tiras}

Este método de lavra é utilizado principalmente na explotação de carvão ou outros tipos de depósitos com forma horizontalizada. Operacionalmente, este método de lavra apresenta semelhanças em relação ao método de "Lavra em Cava", sendo que a principal diferença ocorre na remoção da camada de cobertura da rocha: no método de "Lavra em Cava", este material após removido, é transportado para locais previamente determinados; no caso do método de "Lavra em Tiras", o material (camada de cobertura da rocha) não é transportado para outro locais. Neste caso, após retirado, o material é disposto de forma adjacente ao painel de lavra à medida que a operação de remoção se desenvolve.

A Figura 05 mostra um equipamento de grande porte, com alta capacidade de produção, utilizado, por exemplo, em minas de carvão. O maior equipamento deste 
tipo foi fabricado pela companhia "MAN TAKRAF". O equipamento mostrado, o "RB293", possui 95 metros de altura, 225 metros de comprimento, 14 mil toneladas, necessitando de cinco operadores no controle de suas funções. A capacidade de movimentação diária deste equipamento é de aproximadamente 240 mil metros cúbicos de material.

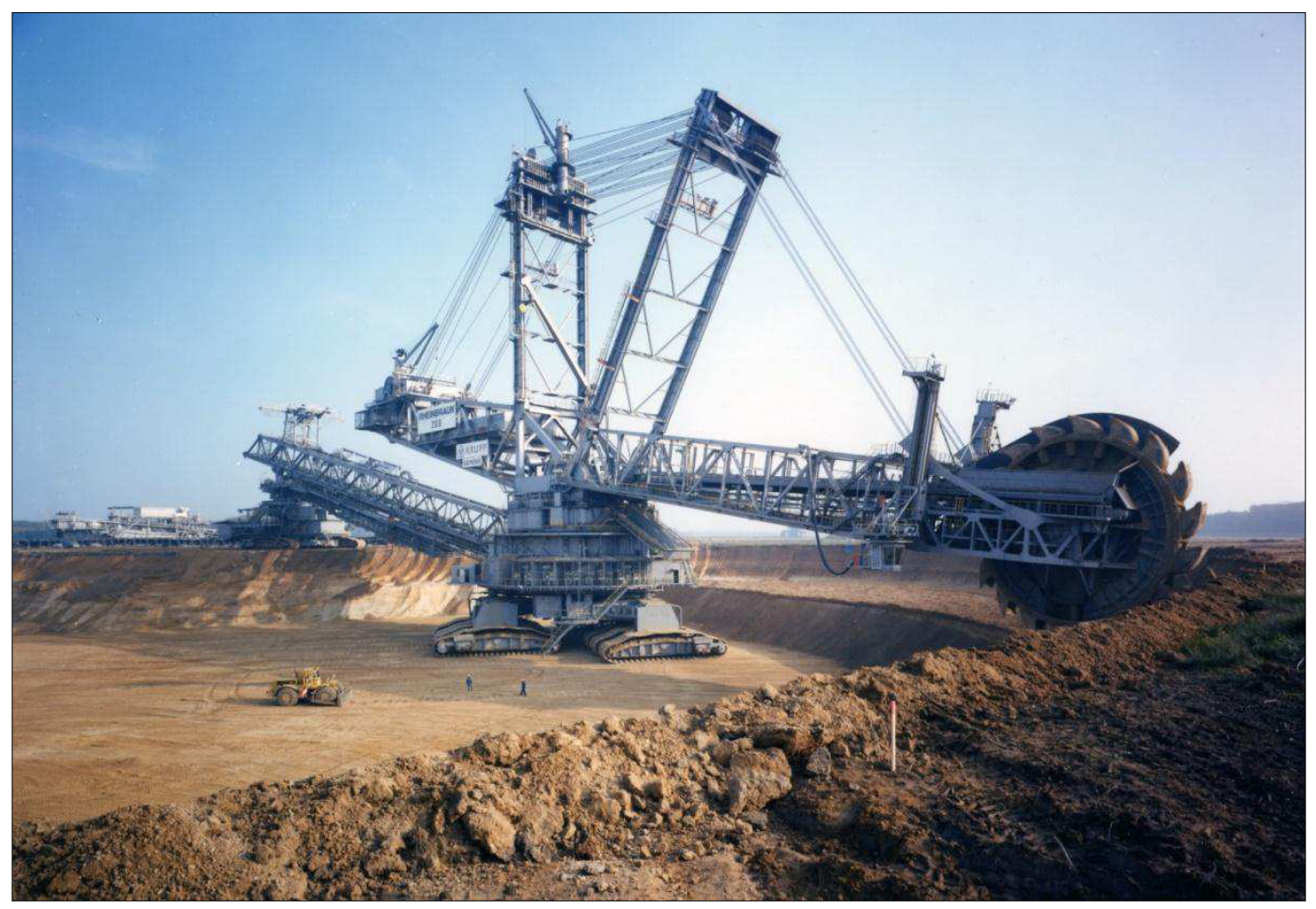

Figura 05 - Escavadora do tipo "Bucket Wheel", utilizada no método de "Lavra em Tiras" (Fonte: http://www.thyssenkrupp.com/en/presse/bilder.htm/\&photo_id=831)

A seguir, são apresentadas as vantagens e desvantagens do método de "Lavra em Tiras", de acordo com Pfleider (1973), Bucyrus-Erie Company (1976) e Kahle e Moseley (1983).

\section{(A) Vantagens}

- Apresenta o mais alto nível de produção do que qualquer outro método a céu aberto;

- Baixo custo de lavra, devido à alta produção;

- Não requer grande desenvolvimento para a lavra; 
- Necessidade de mão-de-obra pouco especializada, se comparada a outros métodos;

- Flexibilidade, pois a produção pode ser facilmente aumentada conforme a demanda;

- Utilização de equipamentos de grande porte, que permitem uma produção elevada;

- Baixo custo de desmonte, já que as bancadas (de grande porte) permitem maior eficiência nas detonações;

- Raramente são necessários suportes nas faces escavadas;

- Boa recuperação e baixa diluição;

- Raramente há a necessidade de transporte do material de cobertura da rocha;

- Boas condições de saúde e segurança nos trabalhos.

(B) Desvantagens

- Profundidade de exploração limitada (90 metros) por aspectos tecnológicos e/ou econômicos;

- Fatores econômicos limitam a relação estéril/minério das operações;

- Impactos visuais, visto que a superfície é afetada pelas operações de lavra;

- Necessidade de altos investimentos em recuperação ambiental;

- Imagem ruim frente à sociedade, devido ao impacto visual provocado pelas operações;

- Em alguns casos, há a necessidade de utilização de trabalho especializado;

- Necessidade de altos investimentos para a aquisição de equipamentos de grande porte; 
- Intempéries climáticas interferem nas operações;

- Necessidade de realização cuidadosa e sequenciada de operações, principalmente durante a fase de remoção da cobertura da rocha;

- As faces escavadas devem ser monitoradas constantemente;

- Necessita de controle continuo de escorregamentos das faces escavadas;

- Necessidade de atenção especial em virtude do porte das operações.

\subsubsection{Lavra de Recuperação Subsuperficial}

Este método de lavra costuma ser aplicado na recuperação de carvão ou outros recursos localizados abaixo da superfície quando é atingido o limite econômico ou a relação estéril/minério máxima do método de "Lavra em Tiras", ou seja, é um método de lavra secundário. Neste caso, uma máquina ou minerador contínuo desenvolve aberturas a partir das faces escavadas. A recuperação dos materiais localizados abaixo da superfície ocorre à medida que o equipamento de escavação avança. Durante essa operação, enquanto o equipamento penetra na subsuperfície, todo o controle operacional é realizado a partir da superfície. Por esse motivo, o método é considerado como um dos métodos mecânicos de lavra a céu aberto.

Existem duas variações deste método: a primeira, o "Auger Mining", utiliza um equipamento tradicional desenvolvido por volta dos anos 50 para realizar aberturas, a partir da parte inferior de uma lavra a céu aberto, na camada de carvão onde estão sendo realizados os trabalhos; a segunda variação do método, o "Highwall Mining" consiste na operação de um equipamento de mineração contínuo guiado remotamente a partir da superfície.

As Figuras 06 e 07 mostram os equipamentos utilizados nas variações do método de "Lavra por Recuperação Subsuperficial". Na Figura 06, é mostrado o equipamento utilizado no "Auger Mining" e, na Figura 07, o equipamento utilizado no "Highwall Mining". 


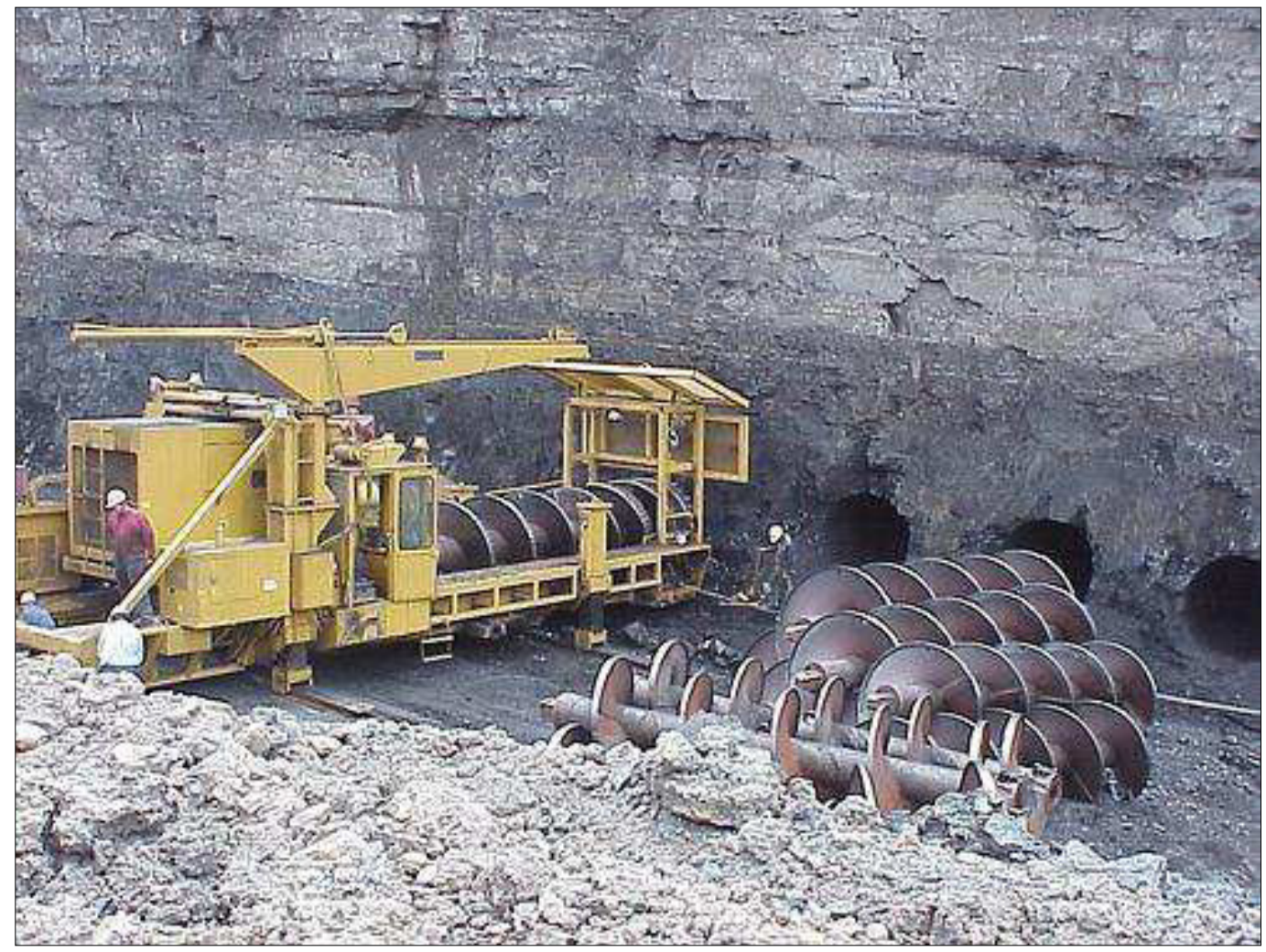

Figura 06 - Equipamento utilizado no método "Auger Mining": trado mecânico operado a partir da superfície para a recuperação de carvão

(Fonte: http://www.sharptraining.com.au/bookings.html)

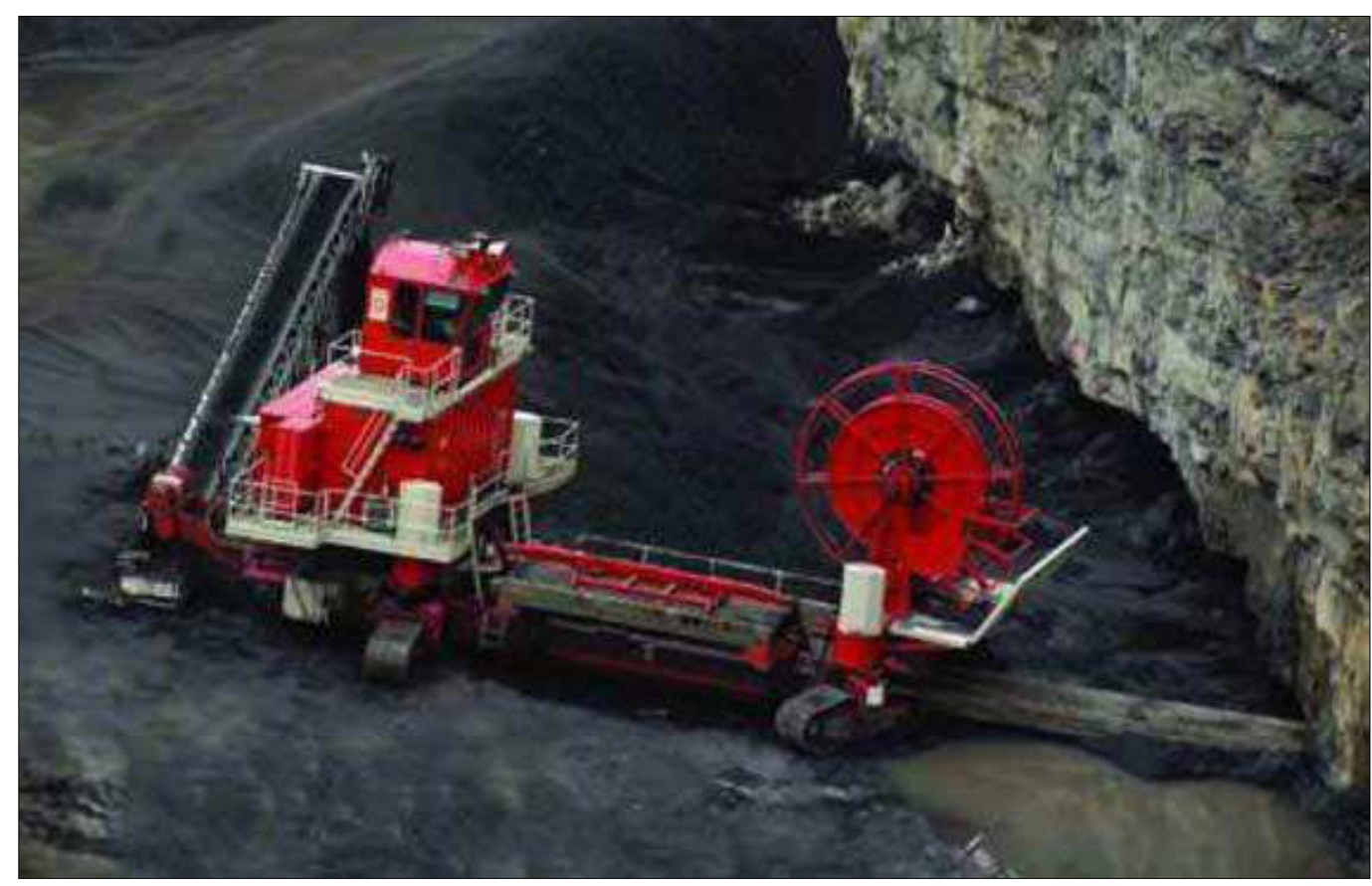

Figura 07 - Equipamento utilizado no método "Highwall Mining": minerador contínuo operado a partir da superfície para a recuperação de carvão

(Fonte: http://www.amcconsultants.ca/2004_may.asp) 
A seguir, são apresentados os aspectos de vantagem e desvantagem da aplicação do método, de acordo com Blakely (1975), Bacon e Utah (1975) e Chadwick (1993).

\section{(A) Vantagens}

- Alta produtividade;

- Baixo custo de lavra;

- Necessidade de pouco desenvolvimento para a realização da operação;

- Necessidade de pouca mão-de-obra;

- Baixo capital de investimento para a aquisição de equipamentos;

- Preservação da superfície topográfica;

- Recuperação de materiais que não seriam aproveitados de forma viável por outros métodos de lavra;

- Boas condições de saúde e segurança nas operações.

(B) Desvantagens

- Aplicação limitada a uma série de restrições associadas ao método de "Lavra em Tiras";

- Baixa recuperação do material de interesse;

- Risco de explosões devido à presença de gás metano oriundo da remoção de carvão;

- A capacidade de produção é limitada à utilização de um equipamento;

- Condições de viabilidade econômica restritas. 


\subsection{Lavra a Céu Aberto por Sistemas de Correias}

De acordo com Silva (1994), a primeira utilização de um sistema de transportador de correias projetado para uma aplicação industrial ocorreu em 1891, em New JerseyUSA, para o transporte de minério na Mina Ogden. O projeto dos roletes deste sistema foi realizado com a participação de Thomas A. Edson, idealizador de inúmeras outras invenções.

No Brasil, segundo LOPES (2010), a maior utilização de sistemas de correias teve início após o fim da Segunda Guerra Mundial, com a mecanização da Mina de Cauê, tendo a partir da década de 60, utilização mais intensa com a implantação de instalações modernas no porto de Tubarão, localizado na cidade de Vitória - ES.

Outro importante exemplo da utilização de transportadores de correias na mineração é a empresa SAMARCO S/A, que iniciou suas atividades ao ano de 1977. Este caso foi considerado inovador na época, uma vez que $100 \%$ do material lavrado era movimentado por sistemas de correias. Atualmente, a relação entre utilização de correias transportadoras e caminhões é de $70 \%$ e $30 \%$, respectivamente [Lopes (2010)].

Basicamente, os transportadores de correias são classificadoos de acordo com a distância de transporte do material: Correias Coletoras, Correias de Bancada e Correias de Longa Distância.

\subsubsection{Transportador de Correias Coletoras}

Na mineração, este tipo de equipamento é utilizado para transportar materiais dentro da cava onde está sendo realizada a lavra. Neste caso, os transportadores de bancada alimentam o material nas correias coletoras, que transportam o minério lavrado para pilhas de estoque ou para as correias de longa distância.

A Figura 08 mostra o arranjo de correias coletoras que transportam materiais para pilhas de estoque distintas. 


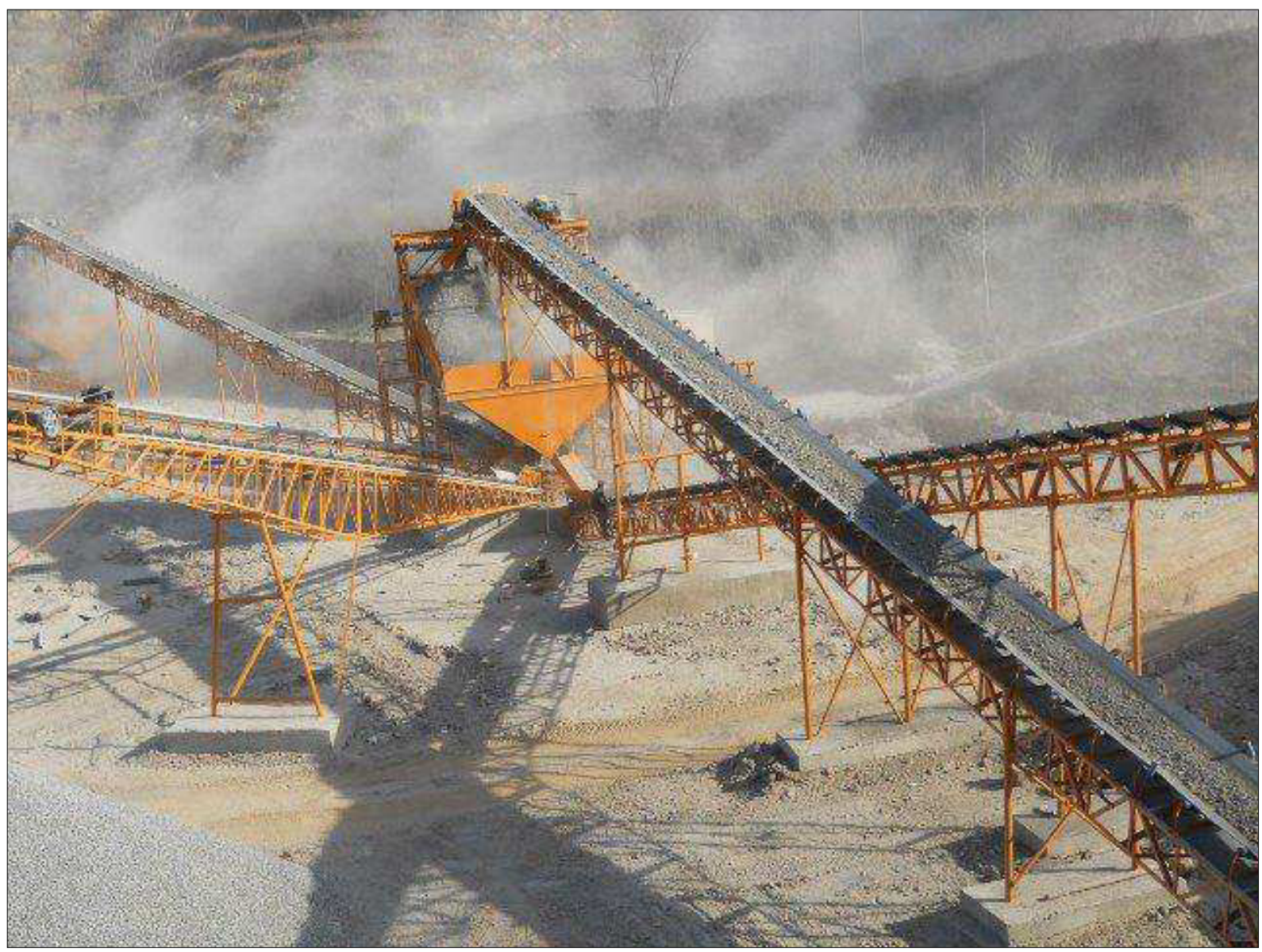

Figura 08 - Transportador de correias coletoras transportando materiais para pilhas de estoque distintas

(Fonte: http://portuguese.alibaba.com/product-gs-img/steeply-inclined-mining-belt-conveyor-system570452287.html)

A capacidade de produção desses equipamentos é variada, sendo mais comuns aqueles com capacidades entre 3.300 e 3.800 toneladas por hora.

\subsubsection{Transportador de Correias de Bancada}

As principais características que estes equipamentos devem apresentar são mobilidade e versatilidade operacional. Os transportadores de bancada são utilizados na lavra com a função de alimentar os transportadores coletores. Visando atender a demanda de mobilidade, este tipo de equipamento deve ser montado sobre estruturas móveis de aço, de modo que sua locomoção na lavra seja facilitada. Comparados aos transportadores de longa distância, apresentam menor nível de automação e utilizam revestimentos de menor resistência. Neste caso, este tipo de equipamento necessita de acompanhamento operacional contínuo. 
A Figura 09 mostra o exemplo de um transportador de correia de bancada.

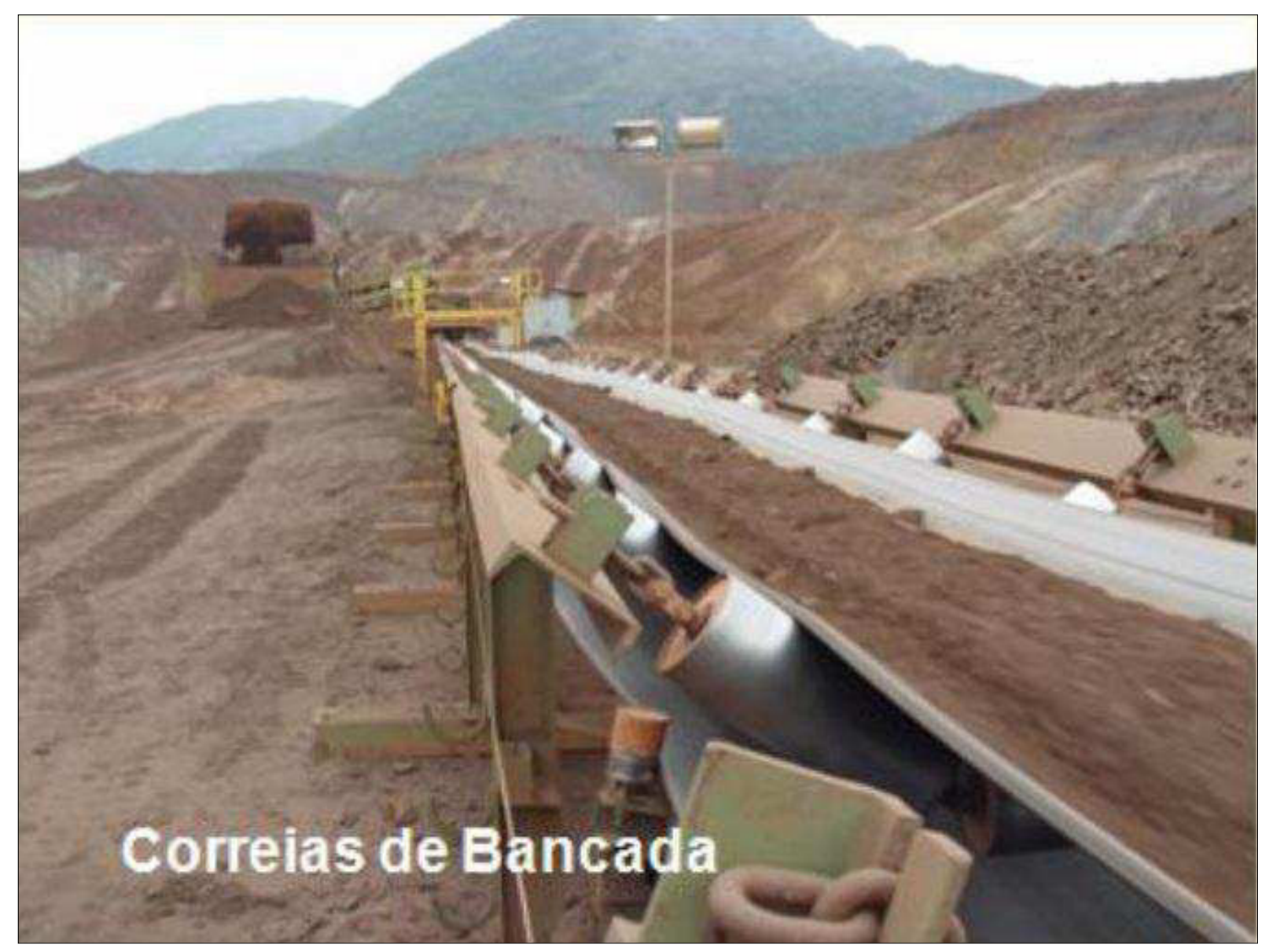

Figura 09 - Vista de uma correia de bancada da mina de Alegria [(Fonte: Lopes (2010)]

\subsubsection{Transportador de Correias de Longa Distância}

Este tipo de equipamento é projetado para o transporte de materiais a grandes distâncias. Os transportadores deste tipo são montados em estruturas fixas, a citar, por exemplo, estruturas de concreto. A seguir, algumas características deste tipo de equipamento:

- Acionamentos elétricos mais elaborados e tapetes de maior resistência;

- Automação mais elaborada, devido à distância entre o centro de controle;

- Necessidade de número reduzido de mão-de-obra; 
- Capacidade de operação entre 3.800 e 4.500 toneladas por hora.

A Figura 10 mostra o exemplo de um transportador de correia de longa distância.

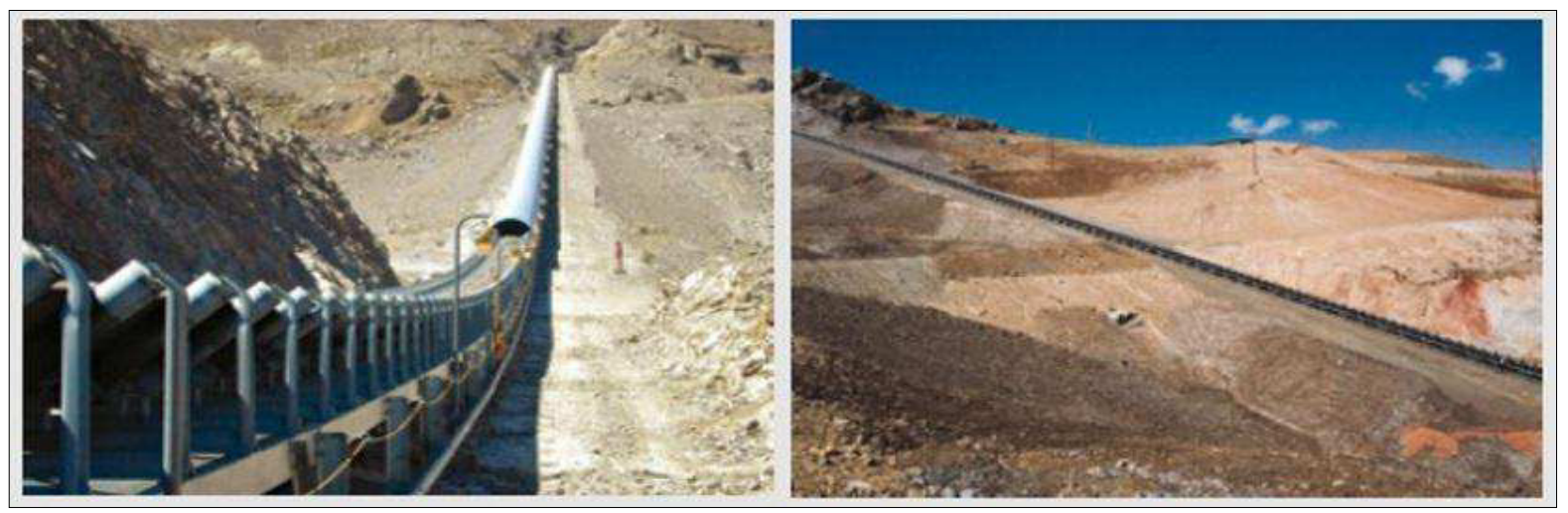

Figura 10 - Transportador de Correia de Longa Distância utilizado na mina Pierina, Peru (Fonte: http://www.phoenix-conveyor-belt-systems.com)

A Figura 11 mostra a mina Pierina ${ }^{8}$, localizada no Peru.

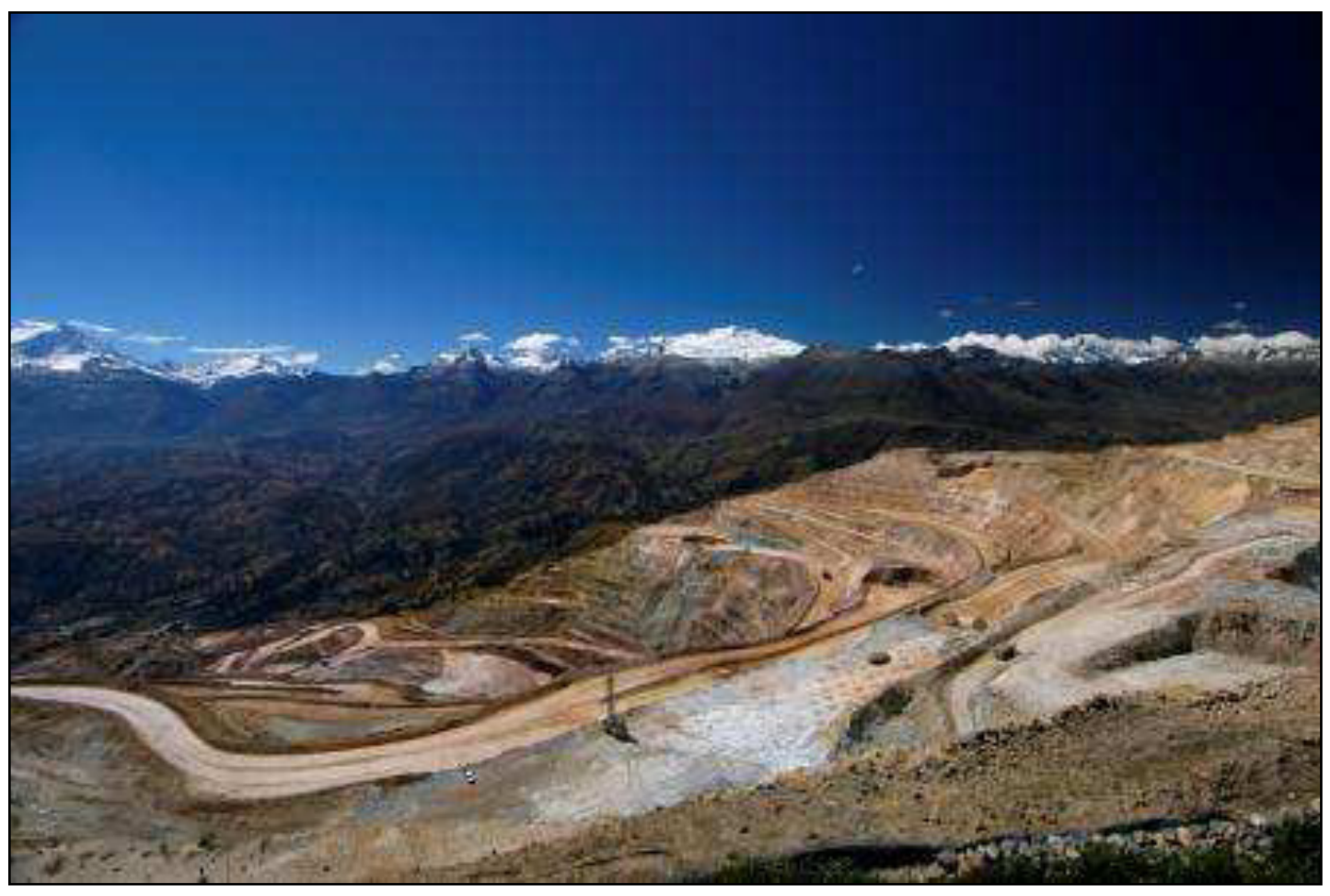

Figura 11 - Vista da Mina Pierina, Cordilheira dos Andes, Peru (Fonte: http://www.barricksudamerica.com/galeria/pierina.php)

8 A Mina Pierina fica localizada na Cordilheira dos Andes a aproximadamente 10 quilômetros de distância da cidade de Huaraz, Nordeste do Peru. Possui operações do tipo convencional com caminhões e escavadeiras na lavra, sendo que o material lavrado, após britado, é transportado por transportadores de correia até a unidade de beneficiamento. 


\subsubsection{Aspectos Operacionais dos Transportadores de Correias}

Operacionalmente, a utilização de transportadores de correias na mineração ocorre da seguinte maneira:

- O material desmontado nas frentes de lavra é carregado por unidades carregadoras nos chamados carregadores, os quais descarregam o minério nas correias transportadoras;

- A distância máxima entre a frente de lavra e o carregador deve ser de aproximadamente 60 (sessenta) $^{9}$ metros, pois para distâncias maiores que esta, a utilização de caminhões se torna mais rentável;

- Uma vez estabelecido o posicionamento do carregador até o limite máximo de distância até a frente de lavra, faz-se a alocação das correias em intervalos de tempo que dependem da escala de produção;

- Durante o período de reposicionamento das correias em uma frente, a lavra do minério se concentra em outras frentes dentro da mina. Caso a produção dependa do minério de uma frente onde esteja sendo realizada a realocação das correias de transporte, por questões, por exemplo, de qualidade do minério, de modo que a paralisação desta frente não possa ocorrer, o transporte do material lavrado deverá ser feito por caminhões até a normalização das atividades da banda transportadora;

- No carregador ocorre um processo de classificação simples:

(i) Uma grelha horizontal retém inicialmente os blocos de maiores dimensões, que são retirados posteriormente pelas unidades carregadoras (percebe-se aqui, um ponto de ineficiência do sistema, devido ao aumento das horas improdutivas de trabalho do equipamento de carga);

\footnotetext{
9 Valor de referência esclarecido pelo Prof. Dr. Wilson Trigueiro de Sousa, da Escola de Minas da
} Univiersidade Federal de Ouro Preto - UFOP. 
(ii) O material que passa pela grelha classificatória inicial é retomado por um alimentador e descarregado logo em seguida numa grelha vibratória localizada acima da correia transportadora;

(iii) O material passante da grelha vibratória é transportado pelo sistema de correias transportadoras até a unidade de beneficiamento seguindo $o$ caminho: correias de bancada, correias coletoras e, por fim, correias de longa distância;

(iv) A parte retida, tanto da grelha inicial quanto da grelha vibratória é direcionada para pilhas de estéril.

A Figura 12 ilustra, de forma resumida, o arranjo operacional do processo de lavra por transportadores de correias.

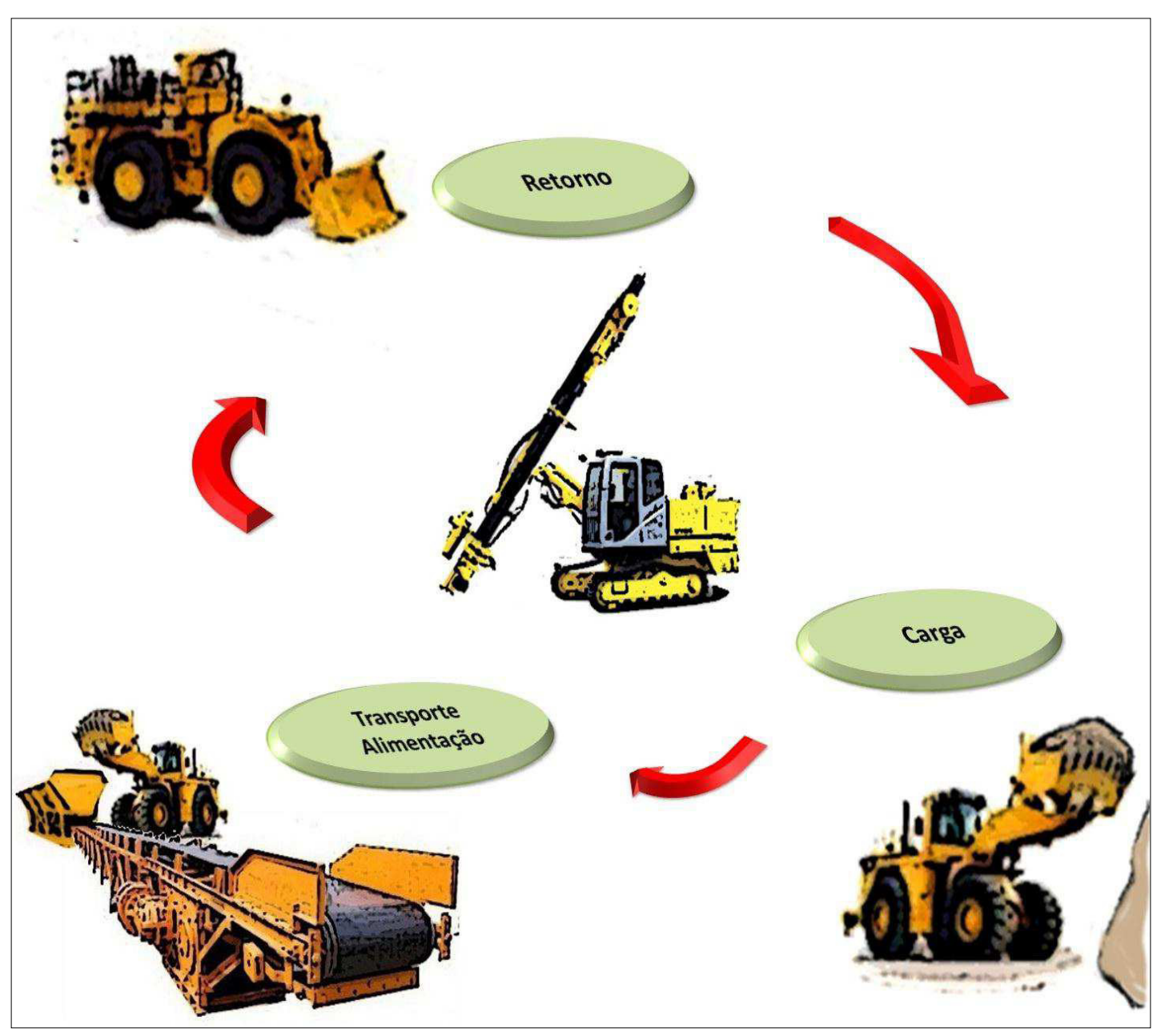

Figura 12 - llustração resumida do arranjo operacional de lavra por transportadores de correias [(Fonte: Adaptado, Lopes (2010)] 
A seguir, são apresentadas as vantagens e desvantagens da utilização de transportadores por correias, de acordo com Lopes (2010).

\section{(A) Vantagens}

- Necessidade de poucas estruturas de suporte, uma vez que geralmente são instaladas na superfície;

- Não apresenta perdas de eficiência em planos de inclinação de até 30\%;

- Facilidade de transposição de obstáculos;

- Demanda uniforme de energia elétrica;

- Baixo custo de manutenção;

- Possibilidade de geração de energia elétrica, em caso de transportes descendentes;

- Necessidade de pouca mão-de-obra ${ }^{10}$;

- Possíveis intempéries do tempo não paralisam as operações;

- Menores riscos de acidentes nas operações.

(B) Desvantagens

- Devem ser posicionadas perto das frentes de lavra;

- Necessidade de paradas da frente de lavra para reposicionamento das correias;

- A produtividade dos equipamentos de carga varia em função da distância entre a frente e o carregador;

- Horas improdutivas, devido a limpezas das praças e manobras;

10 De acordo com CEMA (1997), um ou dois operadores são suficientes para realizar o monitoramento de longos trechos de bandas transportadoras em operação. 
- Dificuldades para a garantia da qualidade blendagem, devido ao posicionamento das correias na cava;

- Necessidade de planejamento detalhado de operações;

- As correias não podem ser deslocadas quando há necessidade de realização de desmonte por explosivos;

- Limite de granulomentria do material transportado;

- As unidades carregadoras são mais exigidas, devido às maiores distâncias de transporte entre a frente e o carregador;

- Necessidade de mão-de-obra especializada para as unidades carregadoras para este tipo de operação.

\subsection{Lavra por Britagem "In Pit” Autopropelida}

Segundo Peltomaki (1991), a primeira máquina de britagem móvel foi apresentada ao ano de 1921. Esta máquina era produzida pela "LOCOMO OU" e funcionava a vapor.

Ao ano de 1956, segundo Lopes (2010), foi instalado o primeiro britador móvel em uma pedreira, na cidade de Hover, Alemanha Ocidental. Neste caso, a mina operava com o transporte de materiais de forma contínua por meio de sistemas de correias transportadoras, reduzindo, desta maneira, os custos de manutenção de vias.

Ainda, segundo este autor, nos dez anos subseqüentes, outras dez unidades foram montadas e, a partir do ano de 1996, estes equipamentos começaram a ter maior aceitação nas minas, incentivando novos fabricantes a investirem em projetos de fabricação de unidades de britagem móvel.

De acordo com Earl e Thomas (1992), os sistemas de britagem "in pit" autopropelida são classificados em: Britagem Móvel e Britagem Semimóvel. 


\subsubsection{Britagem Móvel}

Equipamentos deste tipo trabalham nos bancos da mina e sua locomoção ao longo da cava ocorre de forma autônoma. Quanto à alimentação, estes equipamentos podem ser:

- Autoalimentados: o próprio equipamento realiza a fragmentação, neste caso mecânica, do material. Este tipo de equipamento é conhecido como minerador contínuo (Figura 13);

- Alimentados por Unidades Carregadoras: a sua alimentação se dá por meio da utilização de unidades carregadoras que transportam o material desmontado até a posição onde se encontra o equipamento (Figura 14).

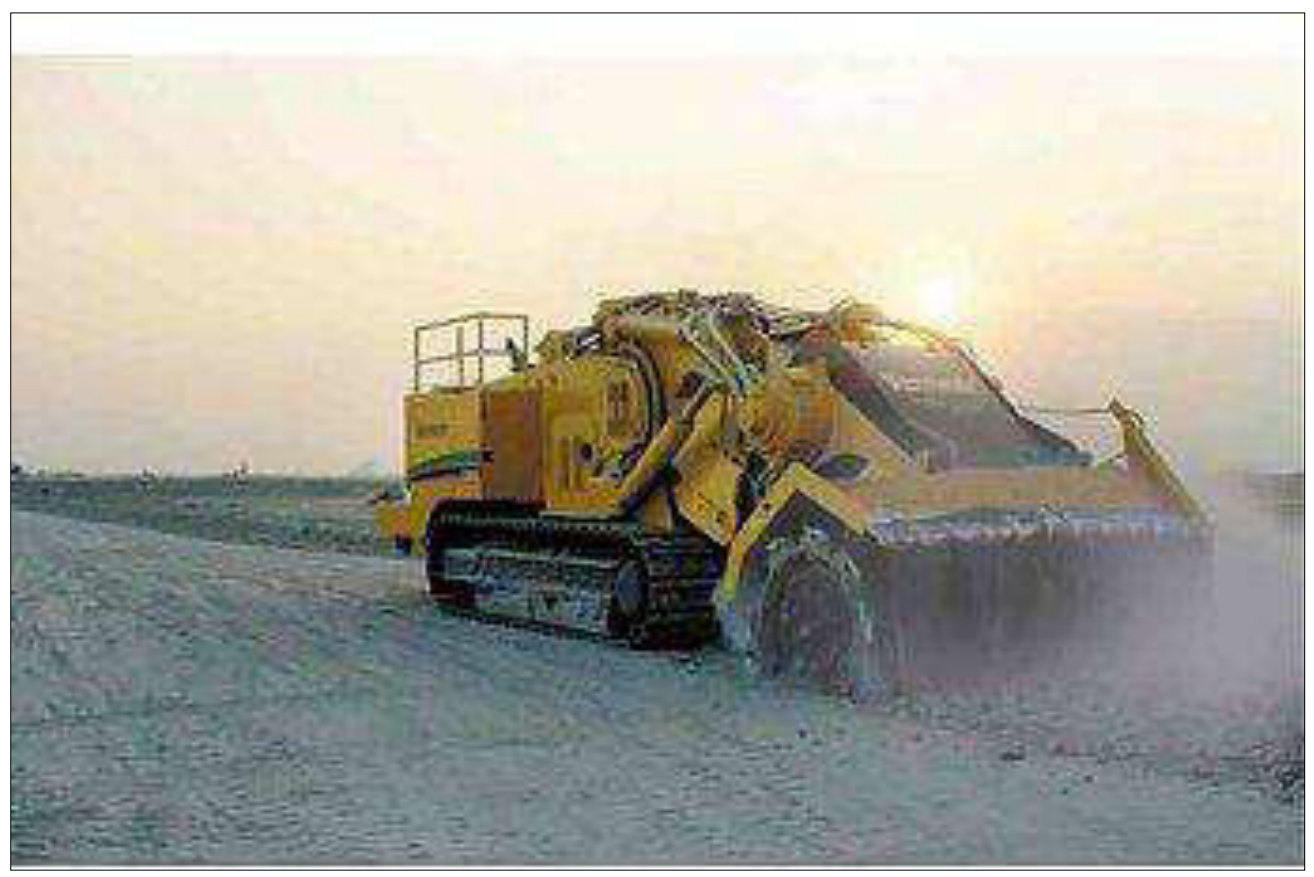

Figura 13 - Britagem móvel autoalimentada (minerador contínuo) (Fonte: http://www.vermeer.pt/produtos/escavacao-especializada/mineracao-de-superficie/) 


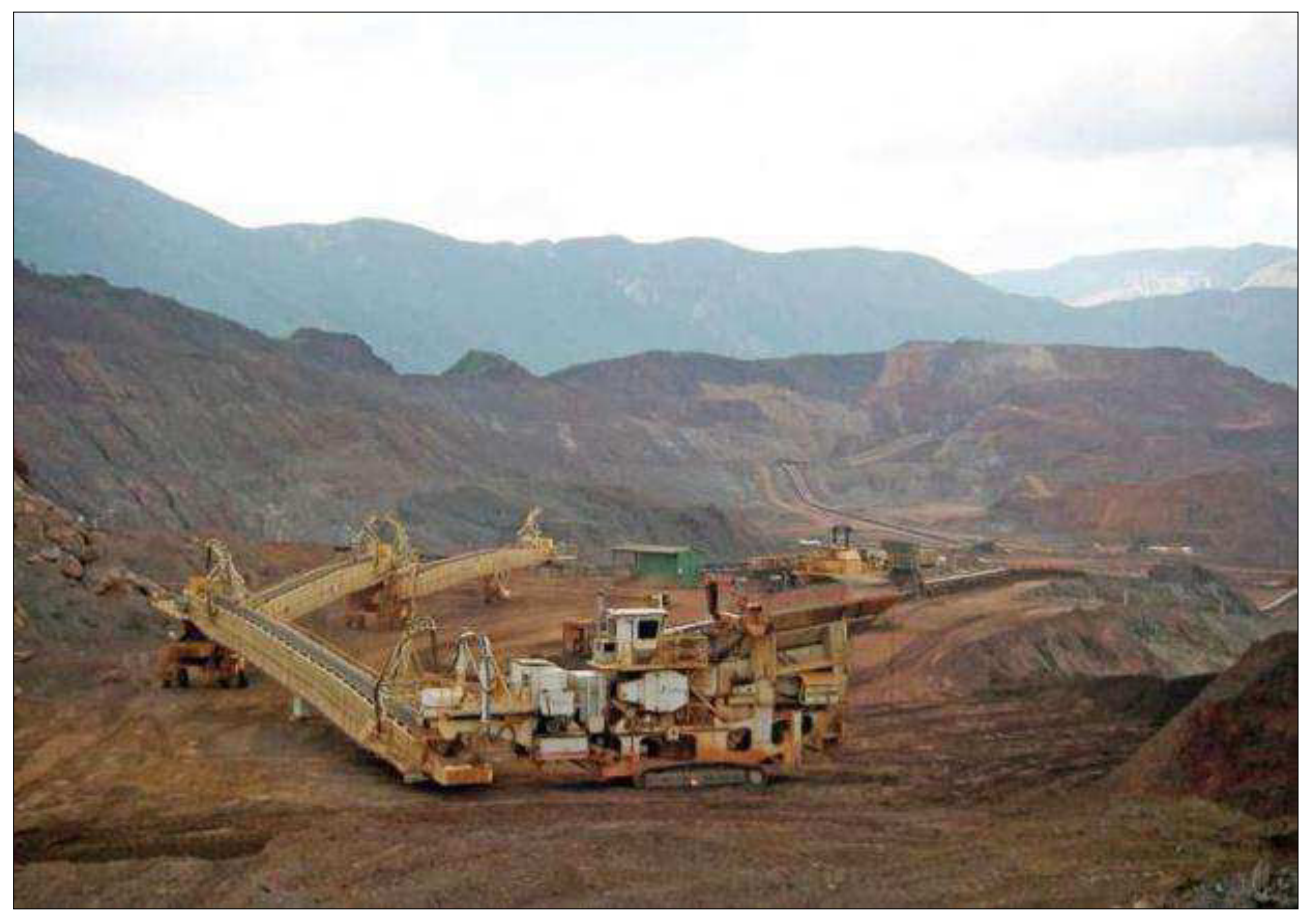

Figura 14 - Britagem móvel alimentada por unidades carregadoras [(Fonte: Lopes(2010)]

\subsubsection{Britagem Semimóvel}

Estes equipamentos trabalham nas proximidades da frente de lavra, mas com menor mobilidade, se comparados aos equipamentos móveis. Neste caso, o mecanismo de locomoção é parte integrante da estrutura do britador.

A Figura 15 mostra o exemplo de um sistema de britagem semimóvel. 


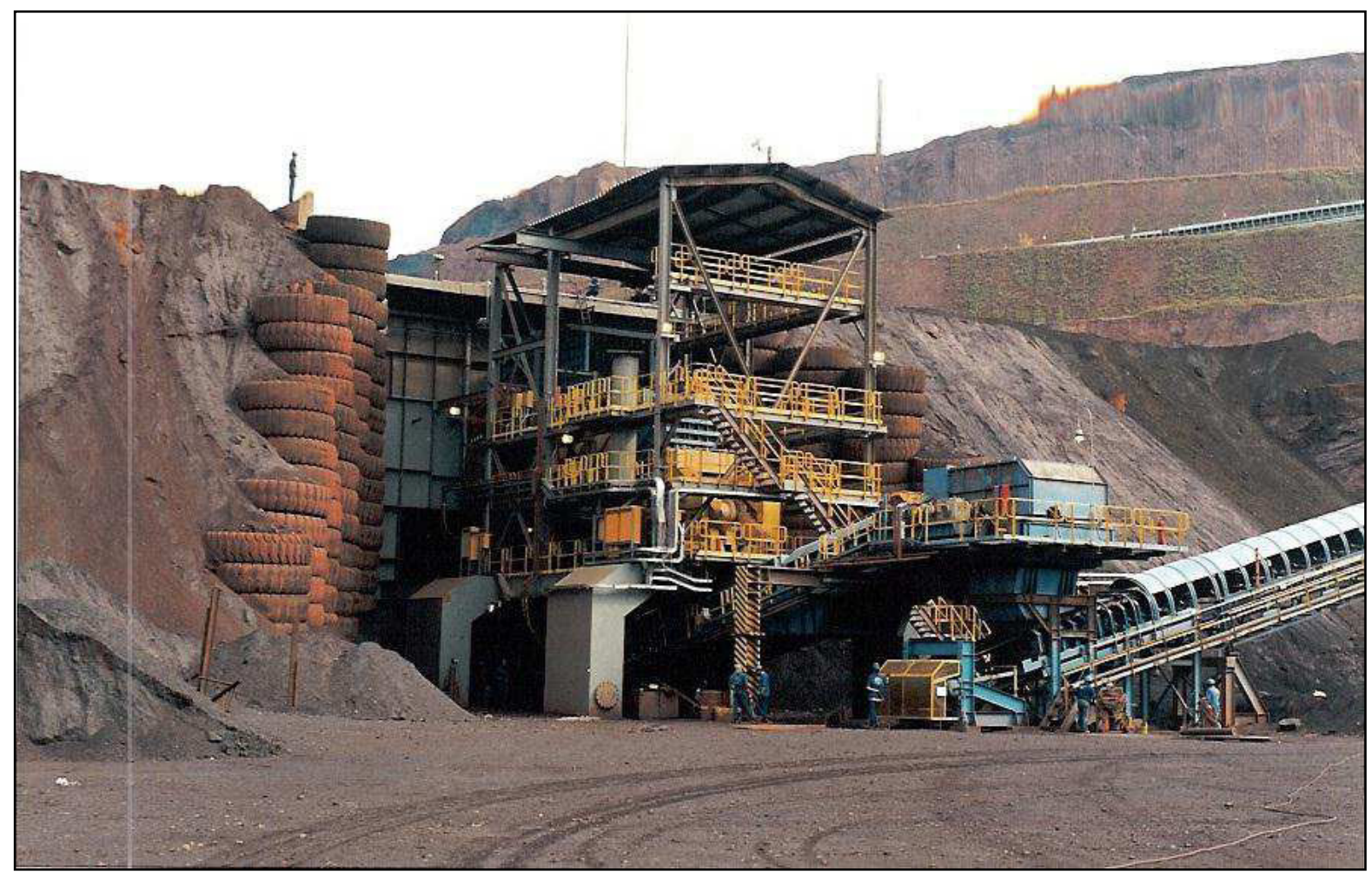

Figura 15 - Unidade de britagem semimóvel ${ }^{11}$

(Fonte: http://www.tkfla.com.br/produtos/mineracao/mineracao/attachment/britagem-semi-movelsemi-mobile-crushing/)

\subsubsection{Aspectos Operacionais da Britagem "In Pit” Autopropelida}

Operacionalmente, a utilização de unidades de britagem "in pif" autopropelidas requer uma série de medidas de planejamento e execução das atividades a serem realizadas, a citar:

- As bancadas de lavra devem ser planejadas para terem, no mínimo, cem metros de extensão e formas aplainadas;

- Quando for necessária a realização de uma lavra seletiva, que demanda mudanças nos locais de operações, devem ser abertas e mantidas outras frentes, de modo manter a qualidade do minério que alimenta a unidade de beneficiamento;

11 Na Figura 15, percebe-se que a unidade de britagem se localiza nas proximidades da lavra, dentro da própria cava. Neste caso, mesmo se tratando de uma estrutura de grande porte, esta unidade de britagem pode ser realocada, o que a caracteriza como uma unidade semimóvel. 
- Quando a unidade de britagem precisar se deslocar de um banco para outro, manobra que demanda tempo para a sua execução, a produção fica prejudicada. Com o objetivo de contornar esse problema, mais de uma unidade de britagem pode ser utilizada na mina;

- Devido a questões relacionadas ao espaço disponível para realização de manobras, este tipo de equipamento costuma ser utilizado em minas de médio a grande portes;

- A alimentação do material é feita pela própria unidade de britagem (caso de um minerador contínuo) ou por meio de uma unidade de carregamento auxiliar. Em seguida, o material é britado pelo próprio sistema da máquina e, na maioria dos casos, transportado por sistemas de correias até o seu destino final;

- Neste tipo de operação, mesmo que seja necessária a utilização de unidades de carregamento, os equipamentos não sofrerão desgaste excessivo por se deslocarem grandes distâncias, uma vez que o sistema autopropelido de britagem pode acompanhar o avanço de suas operações na cava;

- De acordo com Zimmermann e Kruse (2006), para este tipo de operação, os equipamentos de carga mais indicados à alimentação da britagem móvel são as retroescavadoras. As justificativas, segundo os autores, são:

(i) Possibilidade de operar em cima da pilha de minério desmontado. Neste caso, a distância até a alimentação da britagem "in pit" será menor, diminuindo o tempo de ciclo do equipamento;

(ii) Bom controle durante a alimentação e facilidade de separação dos blocos de maiores dimensões na entrada do britador;

(iii) Boa mobilidade operacional, o que se torna mais importante quando há a necessidade de alimentar a britagem com minérios de vários pontos da frente de lavra;

(iv) Dentre os equipamentos de carga, as retroescavadoras são os que apresentam o menor custo operacional; 
- Ainda, segundo estes autores, sendo os equipamentos mais indicados para a alimentação dos sistemas de britagem “in pit”, as retroescavadoras são mais seletivas em relação aos blocos carregados, apresentando menor variabilidade na alimentação;

- Escavadoras do tipo "Shovel" também podem ser utilizadas neste tipo de operação, porém, apresentando menor controle durante a alimentação e menor seletividade dos blocos. Além disso, o porte do equipamento costuma ser superdimensionado devido ao maior tempo de ciclo de carregamento;

A Tabela 1 apresenta, segundo Zimmermann e Kruse (2006), um comparativo entre os equipamentos de carga utilizados na alimentação dos sistemas de britagem "in pif".

Tabela 1 - Comparativo dos equipamentos de carregamento utilizados para a alimentação de sistemas de britagem "in pit"

\begin{tabular}{|c|c|c|c|}
\hline Parâmentros & Retroescavadora & Escavadora & $\begin{array}{l}\text { Pá carregadora } \\
\text { Pneumática }\end{array}$ \\
\hline $\begin{array}{l}\text { Controle do tamanho dos } \\
\text { blocos na alimentação }\end{array}$ & Excelente & Bom & Ruim \\
\hline $\begin{array}{l}\text { Controle da variabilidade } \\
\text { na alimentação }\end{array}$ & Excelente & Excelente & Ruim \\
\hline Tamanho e capacidade & $\begin{array}{l}\text { O tamanho é selecionado } \\
\text { em função da capacidade } \\
\text { requerida }\end{array}$ & $\begin{array}{l}\text { Há a necessidade de } \\
\text { aumentar o porte do } \\
\text { equipamento para } \\
\text { alcançar a alimentação }\end{array}$ & $\begin{array}{l}\text { O tamanho é definido em } \\
\text { função da capacidade e } \\
\text { distância até alimentação }\end{array}$ \\
\hline Escavação & Excelente & Excelente & Bom \\
\hline Alcance de alimentação & 5 a 10 metros & 5 a 10 metros & 50 a 100 metros \\
\hline Considerações & $\begin{array}{l}\text { Utilizada na maioria dos } \\
\text { casos, oferecendo menor } \\
\text { custo operacional }\end{array}$ & $\begin{array}{l}\text { Pode ser utilizada em } \\
\text { materiais de desmontes } \\
\text { com grande quantidade } \\
\text { de finos, onde grandes } \\
\text { capacidades requeridas } \\
\text { justifiquem o uso de } \\
\text { grandes equipamentos }\end{array}$ & $\begin{array}{l}\text { Possibilita realizar a } \\
\text { blendagem de minérios } \\
\text { de diversos pontos }\end{array}$ \\
\hline
\end{tabular}

[(Fonte: Adaptado, Zimmermann e Kruse (2006)] 
Ainda, no tocante aos equipamentos de carregamento utilizados em minas a céu aberto, Lehtineen (1989) cita que os equipamentos mais utilizados são as escavadoras hidráulicas a cabo e carregadoras sobre rodas. Segundo o autor, a escolha dessas máquinas dependerá do material a ser carregado, dos requisitos de produção, das condições operacionais e das fases subseqüentes da produção. As grandes vantagens da utilização destes equipamentos são a sua mobilidade e versatilidade para diversos cenários de operações.

A seguir, são apresentadas as vantagens e desvantagens da utilização de unidades de britagem "in pit", de acordo com Lopes (2010).

\section{(A) Vantagens}

- Conjunto autopropelido por motor a diesel, havendo a possibilidade de disponibilização de versões elétricas;

- Boa velocidade de locomoção dos conjuntos (até $1 \mathrm{Km} / \mathrm{h}$ );

- A montagem do conjunto na cava não requer obras civis;

- Quando utilizados equipamentos a diesel, não são necessárias instalações elétricas;

- Pouco tempo para montagem e posta-em-marcha das operações;

- Possibilidade de transpor obstáculos mais íngremes (cavas com ângulos de talude mais fechados);

- Menor consumo de combustível, se comparado à utilização de caminhões;

- Menores níveis de ruídos;

- Intempéries climáticas não paralisam as operações;

- Menor risco de acidentes de trabalho; 
- Menor impacto ambiental devido à emissão de menos gases oriundos da queima de combustíveis;

- Alimentação constante, uma vez que o sistema de britagem acompanha a escavadora;

- Menor número de trabalhadores envolvidos nas operações;

- Facilidade de realocação do sistema de britagem;

- Vida útil do equipamento parecida com a das correias transportadoras (cerca de 20 anos).

(B) Desvantagens

- Pouca flexibilidade, uma vez que as frentes de lavra devem estar dentro do raio de operação da britagem móvel;

- A realocação do sistema de britagem na cava requer a paralisação das operações;

- Limpeza e manutenção das praças, bem como a paralisação das operações gera aumento de horas improdutivas de trabalho;

- A disposição das correias de transporte na cava dificulta a manutenção da qualidade das blendagens;

- Necessidade de planejamento operacional detalhado de médio a curto prazo;

- Limitação de deslocamento e distância dos conjuntos de correias de transporte e britagem móvel;

- Granulometria de entrada no britador limitada;

- Necessidade de mão-de-obra especializada para a operação da escavadora. 


\subsection{Equipamentos Autônomos na Mineração}

Segundo Moraes \& Castrucci (2001), a automação é qualquer sistema apoiado em computadores que substitui o trabalho humano, em favor da segurança das pessoas, da qualidade dos produtos, rapidez da produção ou da redução de custos, aperfeiçoando os complexos objetivos das indústrias, dos serviços ou bem estar.

No que tange ao progresso das operações das minas, várias empresas de mineração enxergam a autonomia como um fator chave para o desempenho de suas operações. Nesse contexto, equipamentos que trabalham de forma independente apresentam melhores desempenhos em vários aspectos das operações, sendo os principais o aumento da produtividade e a maior segurança na realização dos trabalhos. De acordo com Rosário (2005), a automação industrial em geral, mas particularmente no que se refere ao caso estudado, automação na indústria mineral, integra toda a eletrônica responsável por hardware, a mecânica na forma de equipamentos e a informática, que será responsável por controlar todo sistema.

Segundo Nebot (2005), com o objetivo de garantir operações que atendam às restrições dos produtos definidos pelos clientes, bem como que permitam lucros aos acionistas, o futuro das operações das minas apresentará as seguintes características:

- Produtos Específicos: os clientes necessitarão, cada vez mais, de produtos específicos, de acordo com suas restrições individuais;

- Flexibilidade: as operações deverão ser mais flexíveis e variadas, de modo a não se concentrar numa única linha de produção;

- Agilidade: capacidade de rápida adaptação das operações num cenário de mercado passível de mudanças frequentes.

Uma das principais justificativas para a utilização de equipamentos autônomos na mineração, principalmente caminhões, é o crescente aumento da demanda por bens minerais e, consequentemente, o aumento nos preços das commodities, o que gera 
a necessidade de movimentação mais rápida, barata, precisa e segura de grandes volumes de materiais.

Quando se fala em automação na mineração, há dois níveis a serem considerados. De acordo com a fabricante de equipamentos Caterpillar, estes níveis são:

- Sistemas Autônomos: por meio da tecnologia de controle remoto, os controladores atuam na maioria das funções das máquinas, mas têm contato direto com o equipamento. Este tipo de sistema permite que os operadores trabalhem em locais seguros, os quais podem estar situados longe dos locais de trabalho físicos. As soluções autônomas propriamente ditas podem eliminar completamente a necessidade de interferência humana direta nas operações dos equipamentos. Neste caso, as máquinas são conduzidas por meio de sistemas de controle que armazenam e gerenciam todas as informações necessárias à execução das operações;

- Sistemas Semiautônomos: este tipo de sistema permite que os controladores trabalhem a partir de um local remoto enquanto automatizam as partes mais significativas dos ciclos de trabalho, ou seja, eliminando o contato direto dos operadores com tarefas entediantes e/ou cansativas.

\subsubsection{Entendendo os Sistemas Autônomos}

De acordo com a fabricante de equipamentos Caterpillar ${ }^{12}$, os componentes básicos de um sistema autônomo de mineração são:

- Sistemas autônomos embarcados em cada equipamento;

- Sistemas de gestão de informações;

- Sistemas de monitoramento das condições operacionais das máquinas;

12 Atualmente, a Caterpillar, também conhecida como "CAT", é a maior fabricante de equipamentos para as indústrias de mineração e construção civil, além de fornecer componentes para outros segmentos industriais, tais como motores e turbinas. 
- Sistemas de controle e orientação de alta precisão baseados em GPS;

- Tecnologias de comunicação em banda larga.

A Figura 16 ilustra o arranjo entre os componentes básicos de um sistema autônomo de mineração.

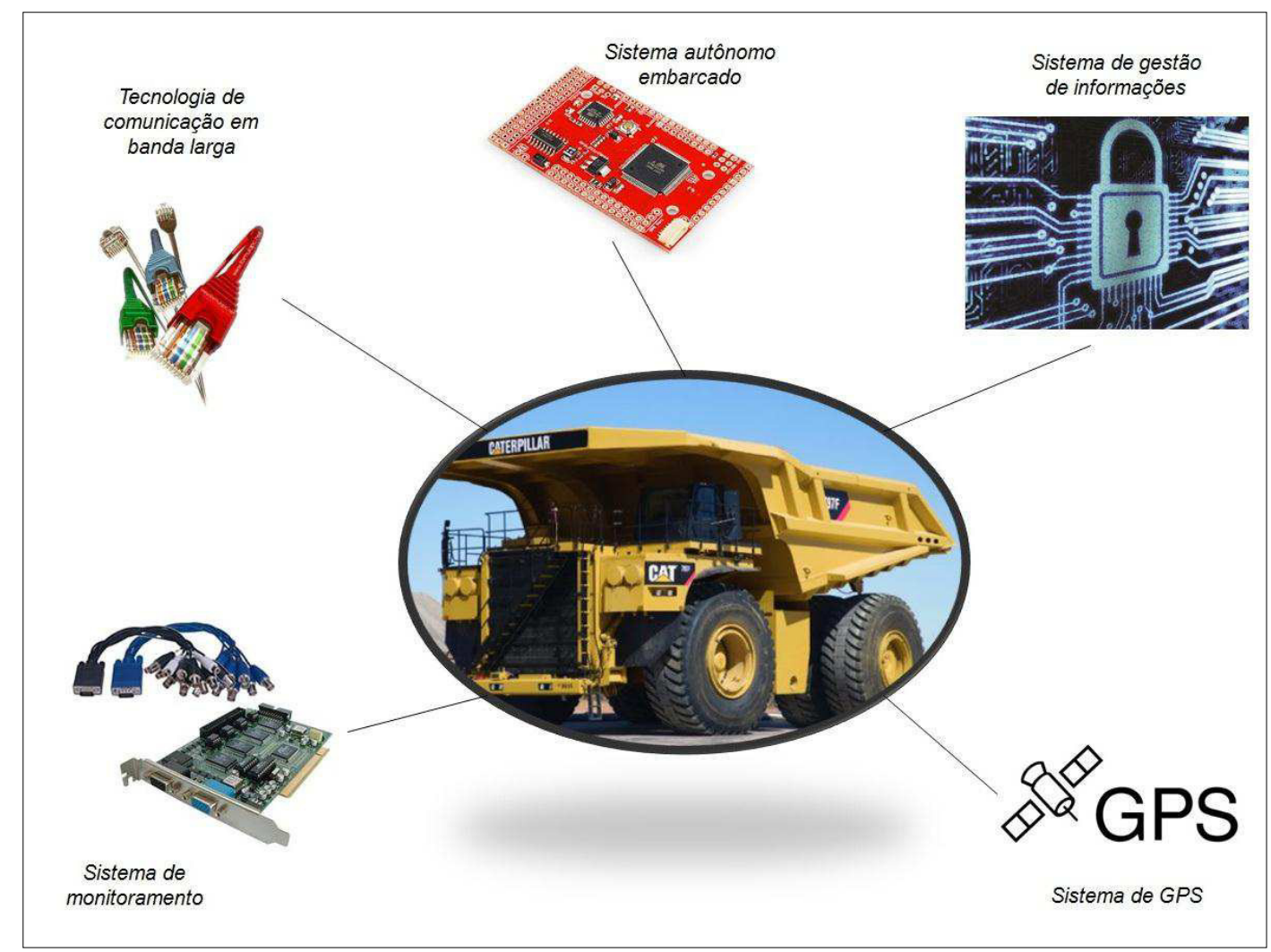

Figura 16 - Arranjo entre os componentes básicos de um sistema autônomo de mineração (Fonte: Arquivo próprio)

A automatização pode ser aplicada não somente a uma simples máquina, mas a um complexo sistema. De acordo com Martins (2007), esses sistemas podem ser extremamente complexos. Porém, ao observá-los cuidadosamente se torna possível identificar características comuns. Assim, segundo o autor, um sistema ou processo de automação possui os seguintes componentes básicos: sensoriamento; comparação e controle; atuação.

1. Sensores: os sensores são responsáveis por fornecer informações do processo para alimentar os controles, como exemplo, o posicionamento de um caminhão em uma cava; 
2. Comparação e Controle: o controlador é o responsável por acionar os atuadores de acordo com as informações fornecidas pelos sensores. Atualmente, há uma tendência dos controles das máquinas serem melhor distribuídos, com microprocessadores controlando uma máquina em particular. Esses controles são normalmente ligados a um controlador central, o qual gerencia todos os equipamentos, os CLP's (Controladores Lógicos Programáveis);

3. Atuação: os atuadores são os responsáveis pela realização do trabalho em si ao qual o processo de automação foi desenvolvido, no caso das minas, os próprios caminhões, escavadoras, etc.

A possibilidade da total automatização do processo pode atingir níveis de complexidades muito elevados. Neste caso, os sistemas são organizados de forma hierárquica, como mostra a Figura 17 , onde os elementos de sensoriamento, controle e atuação pertencem à primeira e segunda camadas.

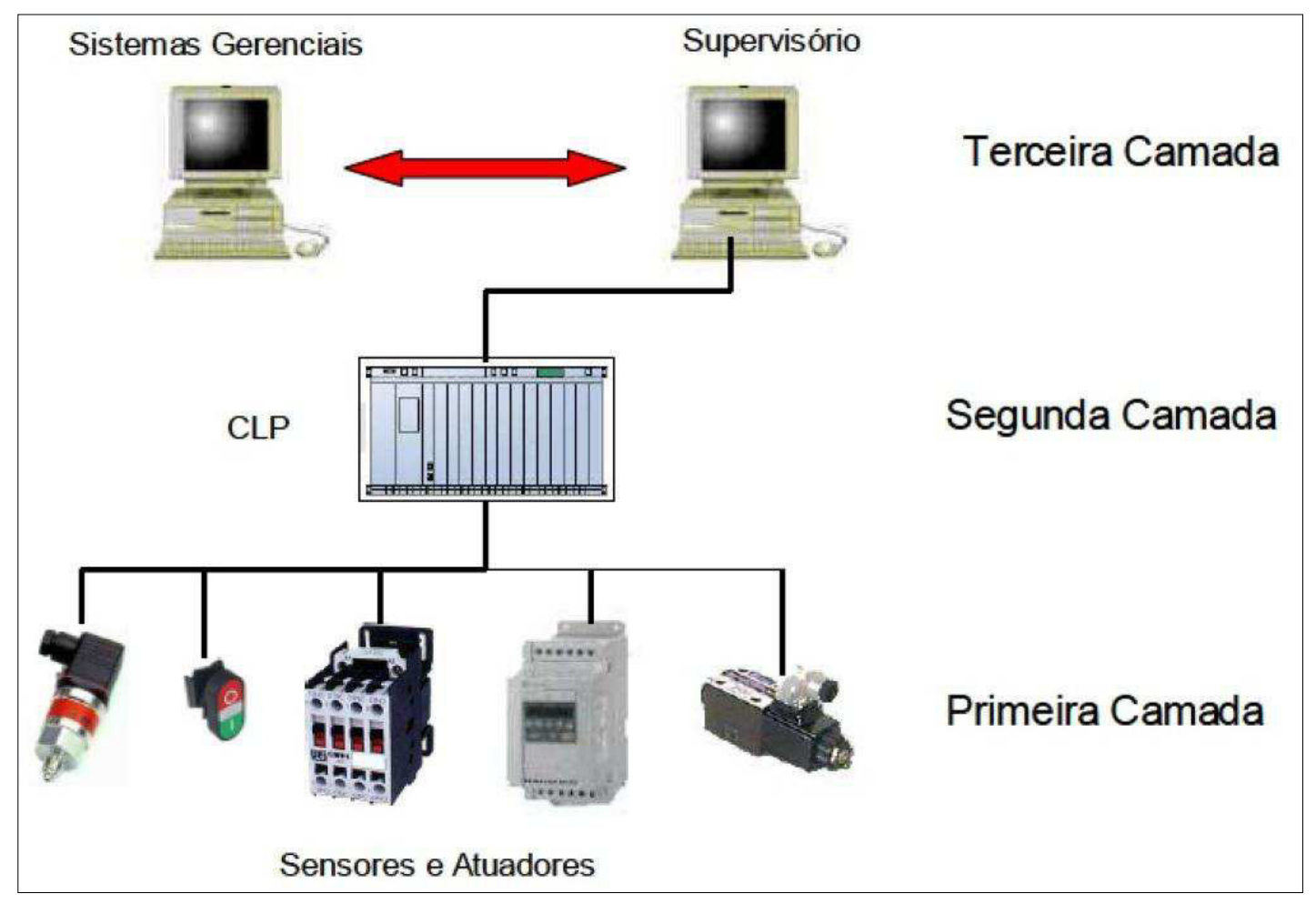

Figura 17 - Arquitetura simplificada de sistemas de automação complexos [(Fonte: Martins (2007)] 


\subsubsection{Benefícios da Automação na Mineração}

Os pontos em que a automação provê maiores benefícios são: desempenho operacional; segurança e mão-de-obra. Esta informação se confirma em Caterpillar (2008), onde os principais benefícios da utilização de equipamentos autônomos na mineração estão relacionados à segurança, eficiência, produtividade, redução de custos e aumento da disponibilidade física (DF) de cada equipamento.

\subsubsection{Desempenho}

Segundo Caterpillar (2008), o maior benefício da utilização de equipamentos autônomos é a uniformidade das operações realizadas. De acordo com Ken Edwards, gerente de tecnologia de mineração da Caterpillar, as ineficiências e as diferenças humanas respondem por milhões de dólares em despesas operacionais ou perdas de receita. Neste cenário, a uniformidade leva ao aumento da eficiência e, consequentemente, aumento da produtividade e redução de custos. Ainda, de acordo com este trabalho, os benefícios potencias da uniformidade das operações são:

- Possibilidade de programação do posicionamento dos caminhões em relação às máquinas de carregamento. Isto elimina a necessidade da busca pelo posicionamento ideal dos caminhões para o carregamento, o que significa perda de tempo e receita em operações não automatizadas;

- O tempo de ciclo dos caminhões será uniforme ao longo dos turnos de operações;

- Uma vez que não há a utilização de operadores, a eficiência dos equipamentos não sofrerá variações causadas por aspectos relacionados a influência humana;

- Todas as verificações de rotina das condições operacionais dos caminhões podem ser feitas no momento do seu abastecimento por meio de sistemas integrados de monitoramento; 
- Como não há necessidade de mudanças de turno, são reduzidas as horas improdutivas de cada equipamento. Além disso, não há a necessidade de movimentação de materiais que não foram conduzidos aos seus destinos corretos em turnos anteriores, no caso de operações não automatizadas;

- Computadores gerenciam as operações dos equipamentos. Isto reduz a queima de combustível, o que gera menores passivos ambientais e menores gastos operacionais.

\subsubsection{Segurança}

Segundo Ed McCord, gerente de produtos da Caterpillar, da área de caminhões de grande porte para mineração, a utilização de um equipamento autônomo terá uma grande influência nas metas de "acidente zero" das empresas. Como exemplo simples, pode-se imaginar o acesso e a saída de operadores a um determinado equipamento. Neste caso, a possibilidade de lesões ocasionados por essa movimentação de pessoal será eliminada com a utilização de equipamentos autônomos.

Outro aspecto importante diz respeito à interação entre os equipamentos da mina. Numa operação automatizada, cada equipamento é gerenciado por sistemas redundantes que trabalham de forma integrada. Isto reduz fortemente a possibilidade de colisões, desvios de rota e má utilização, por exemplo, o que é comum quando se tem operações executadas por operadores humanos.

\subsubsection{Mão-de-Obra}

Geralmente, as minas se localizam em regiões cada vez mais remotas, o que torna mais difícil o direcionamento de mão-de-obra. Devido ao porte cada vez maior dos equipamentos de mina e das restrições operacionais, há a necessidade de treinamentos específicos dos operadores que os utilizarão, o que representa gastos 
significativos de recursos e tempo. Neste sentido, equipamentos autônomos surgem como solução para essa problemática.

De acordo com Ed McCord (Caterpillar), as empresas de mineração buscam a expansão de suas operações e o aumento de sua produtividade em função da crescente demanda. Porém, não conseguem encontrar com facilidade pessoal adequado para complementar seu quadro de funcionários. Desta forma, há a necessidade das empresas alcançarem suas metas por meio da utilização dos funcionários que já possuem.

Segundo Michael Murphy, gerente comercial de mineração autônoma da Caterpillar, a autonomia também tem o papel de atrair uma nova geração de funcionários para as minas. Esta nova geração cresceu familiarizada com a utilização de computadores, sistemas e internet. Desta forma, estarão familiarizados a sensação de estarem "jogando um video-game" proporcionada pela autonomia dos equipamentos.

Outro ponto de relevância é a necessidade de menor infraestrutura nas minas, uma vez que se reduz a quantidade de pessoas envolvidas nas operações, ou seja, quanto menor for o número de pessoas do quadro de funcionários, menor será a necessidade de acomodações, menores áreas destinadas a treinamentos, dentre outros.

\subsubsection{Exemplos de Aplicações}

Como exemplos de aplicação de equipamentos autônomos na mineração, podem ser citados:

- Rio Tinto com a Komatsu: o programa teve início ao ano de 2008 na mina West Angelas, em Pilbara - Austrália. Inicialmente, foram postos em operação cinco caminhões orientados por GPS e sistemas auxiliares de navegação. Ao todo, estes equipamentos realizaram mais de 145 mil ciclos, rodando aproximadamente 450 mil quilômetros e transportando mais de 42 milhões de toneladas de materiais. Posteriormente, esta frota foi transferida para a mina 
de Yadicoogina e complementada com mais cinco caminhões 930E, também de operação autônoma. A Figura 18 mostra um modelo do caminhão 930E da Komatsu.

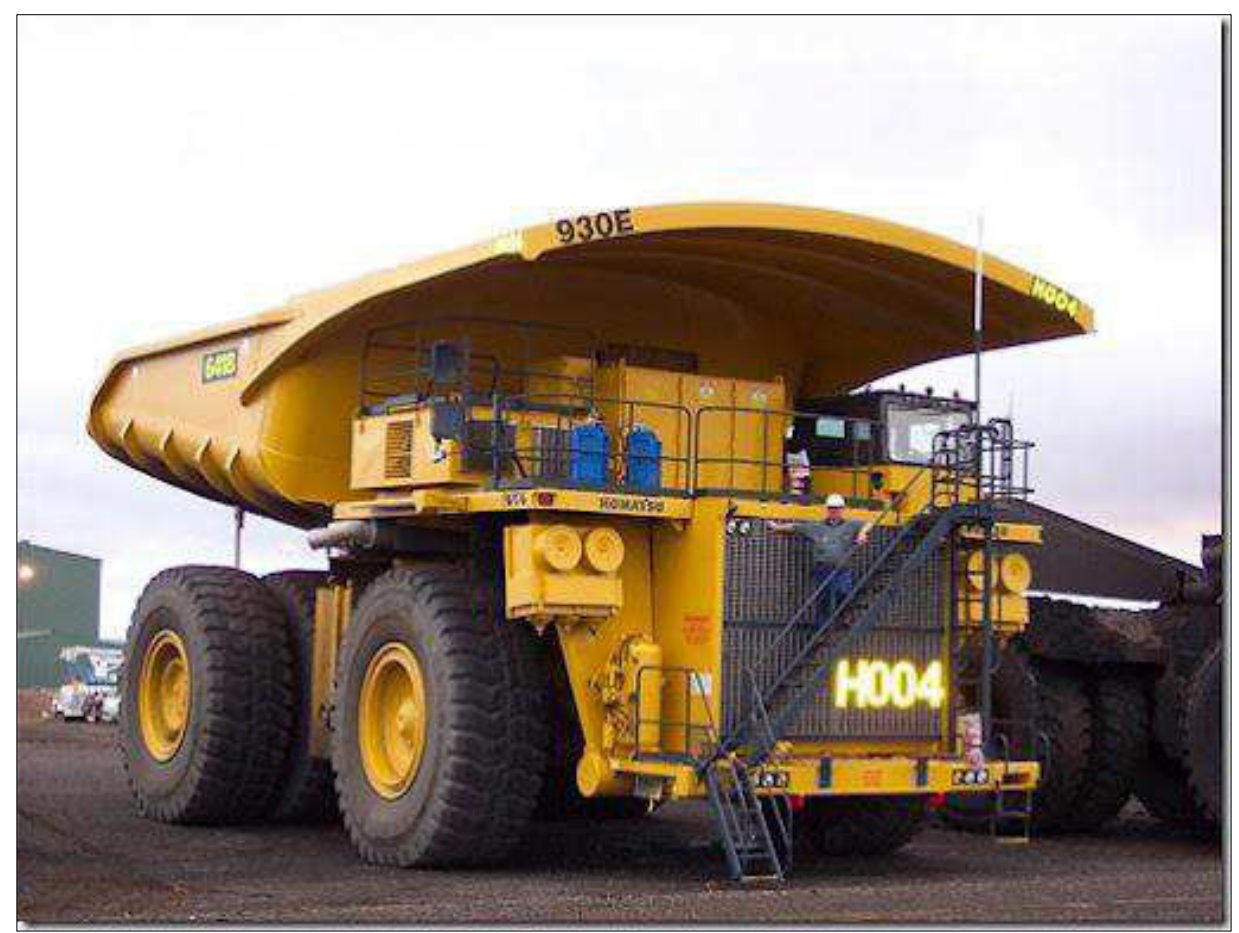

Figura 18 - Caminhão 930E - Komatsu

(Fonte: http://www.imegin.com.br/2012/10/top-10-maiores-caminhoes-do-mundo.html)

A Figura 19 ilustra o sistema autônomo da Komatsu.

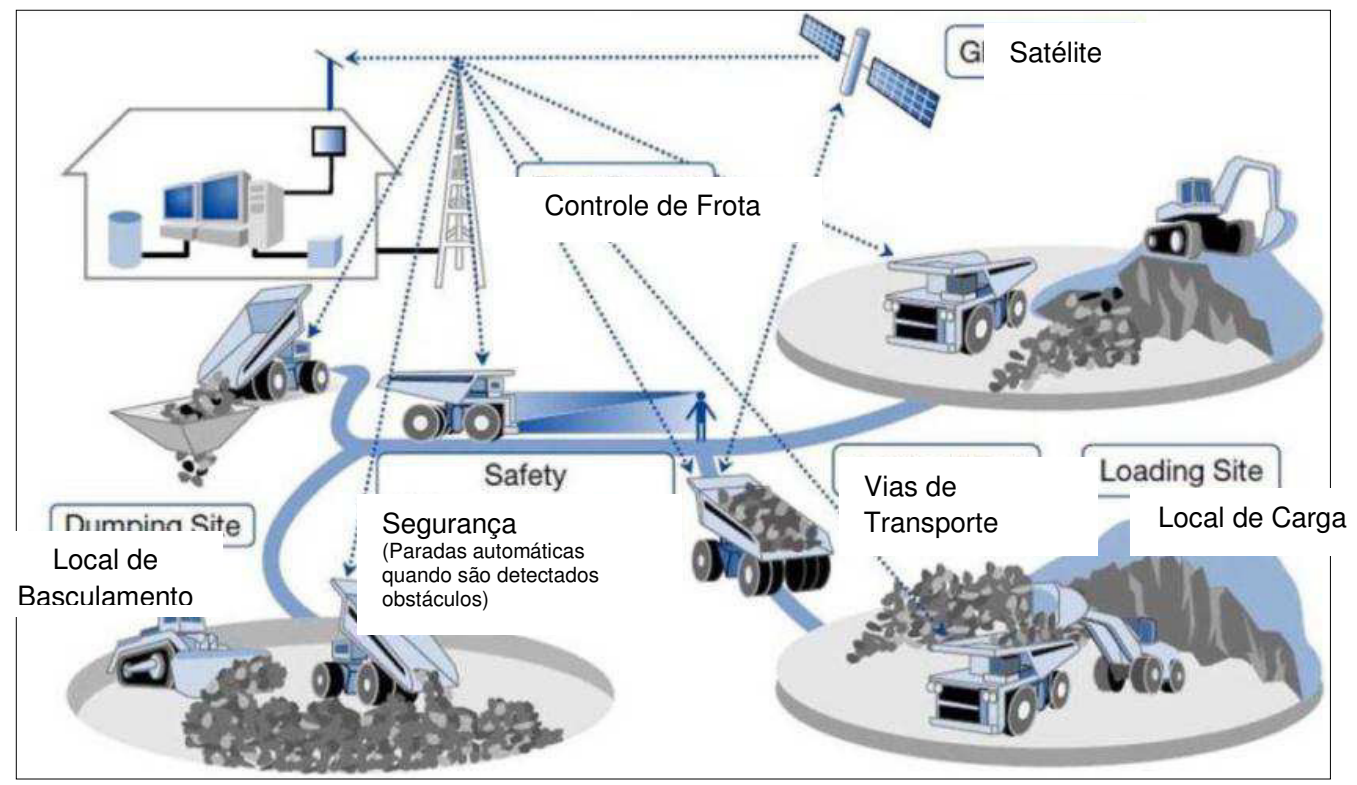

Figura 19 - Sistema de automação de transporte da Komatsu [Fonte: Adaptado de Meech, (2008)] 
- Caterpillar: a fabricante vai exibir na Minexpo seus três modelos de maior capacidade, 797F, 795F e 793F (Figura 20), juntamente com os equipamentos de carga $994 \mathrm{H}$ de alcance estendido e a série $B$ da escavadora 6050 FS hidráulica. No segmento de caminhões autônomos, a empresa foi contratada pela Fortescue, da Austrália, para fornecer 12 caminhões modelo 793F para serem incorporados na mina de Solomon. A frota de equipamentos autônomos nesta mina deverá ser de 45 unidades até 2015.

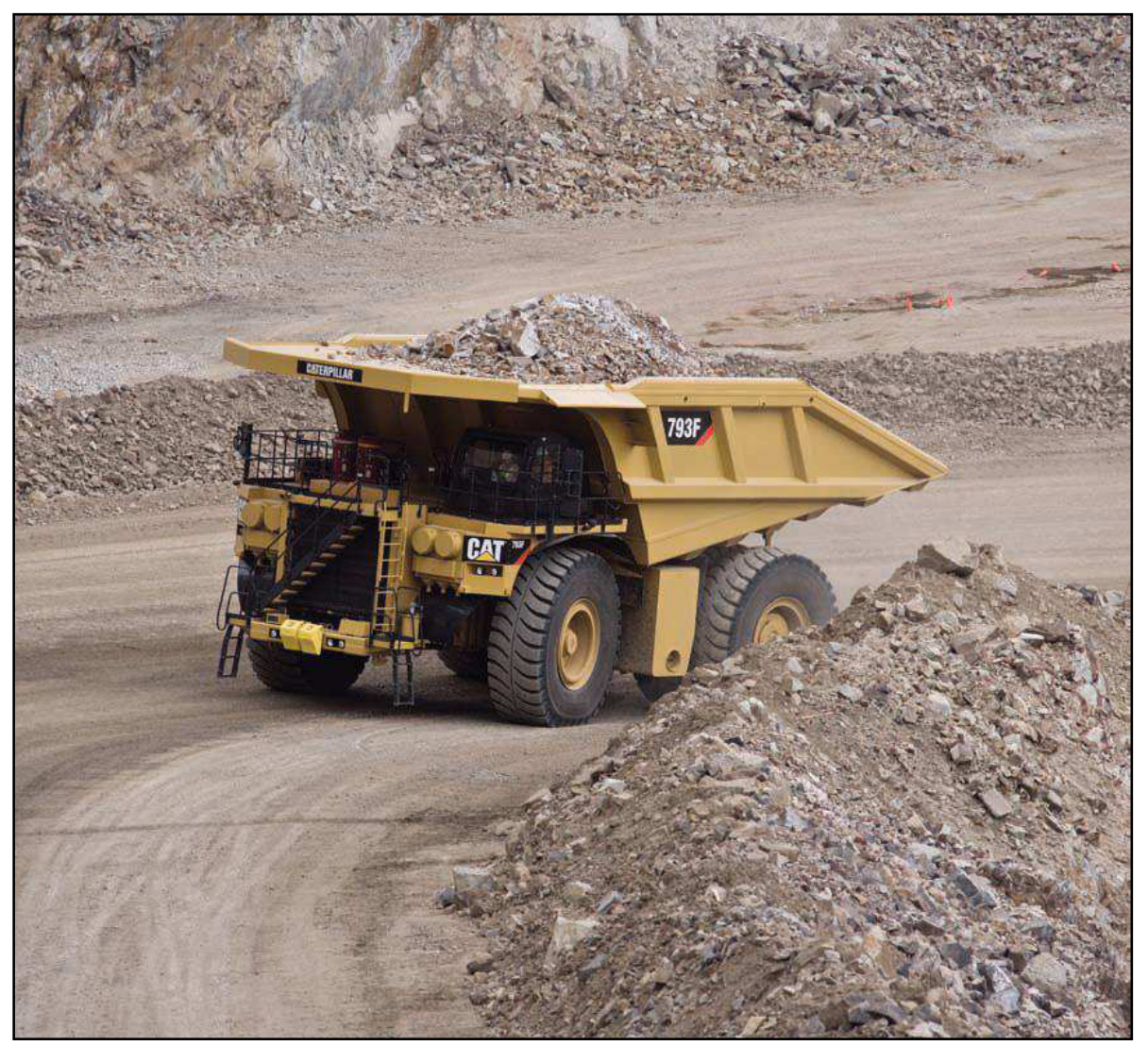

Figura 20 - Caminhão 793F - Caterpillar (Fonte: https://mining.cat.com/cda/layout? $m=435123 \& x=12$ )

\subsubsection{Desafios de Implementação de Sistemas Autônomos}

A indústria mineral vem atualmente confrontando um número de obstáculos já bem conhecidos, tais como falta de recursos humanos qualificados, restrições ambientais e sociais cada vez mais severas e, claro, a necessidade de reduzir custos de forma a se manter competitiva em um mercado flutuante. 
Neste cenário, as empresas enfrentam os maiores desafios na automação no que diz respeito ao desenvolvimento e implantação em suas operações e projetos já em atividade. Os maiores desafios apontados são:

- Integridade: de acordo com Scheding (2000), um dos maiores desafios referentes à utilização de equipamentos autônomos diz respeito à integridade dos sistemas de controle, os quais devem apresentar níveis de redundância suficientes para impedir a probabilidade de ocorrência de acidentes;

- Alto custo de aquisição dos equipamentos e sistemas de suporte: máquinas autônomas e sistemas de gerenciamento e suporte de operações apresentam altos custos de aquisição, embora justifiquem, a curto e médio prazos, ganhos de produtividade e gerem menor demanda de manutenção posteriormente;

- Necessidade de readequação dos padrões atuais de operação das minas: as minas atuais estão projetadas para sistemas convencionais de lavra, os quais foram desenvolvidos há décadas atrás e não atendem mais às perspectivas de evolução dos métodos de lavra;

- Mudanças de paradigmas referentes à automação: a pessoas têm em mente que a implementação de sistemas autônomos gera a perda de postos de trabalho, o que é uma visão incorreta do cenário como um todo. Com a implementação de sistemas autônomos não há a perda de postos de trabalho, mas sim a redefinição de postos de trabalho. Neste caso, por exemplo, os melhores operadores de uma frota de caminhões poderiam ser treinados para serem controladores de suas operações remotamente.

\subsubsection{Perspectivas para a Automação na Mineração}

Segundo Nebot (2005), minas a céu aberto são alocadas de acordo com uma diversidade de condições, tais como: geofísicas, viabilidade econômica, condições de mercado, fatores sociais e ambientais, dentre outros. Nesse modelo, na maioria dos casos, a lavra é realizada de acordo com configurações predefinidas para 
equipamentos que realizam as operações unitárias, como a operação de carregamento e transporte de materiais para pilhas de estéril ou britadores, por exemplo.

Neste tipo de cenário, estima-se que os custos com a operação de transporte e manuseio de materiais podem chegar a somar cerca $50 \%$ do custo total da lavra a céu aberto, conforme Trueman (1997).

Sendo assim é normal que maiores esforços estejam sendo tomados na área em questão, principalmente do que condiz aos benefícios trazidos com o uso de um sistema de caminhões autônomos ("AHT - Autonomous Haulage Trucks"), conforme Nebot (2005).

Atualmente, já existem casos na mineração onde a automação foi adotada com sucesso, como exemplo, o transporte ferroviário do produto final, sistemas de correias transportadoras, dentre outros como: LHD's autônomas, caminhões fora-deestrada autônomos (Soluções Driverless), perfuratrizes autônomas, etc.

Como citado a priori, a operação que apresenta maior potencial de crescimento com a automação na lavra de minas a céu aberto é a de transporte. As tecnologias em crescimento na área de AHT existem ainda em uma forma pré-matura, e estão em desenvolvimento e testes por pelo menos duas das grandes fabricantes de equipamentos, a Komatsu e a Caterpillar, conforme apresentado anteriormente.

Apesar de tudo, automação de um sistema para toda a operação de lavra ainda é um passo a ser dado, pois ainda vários obstáculos até que se cheguem à chamada "mina do futuro". Neste sentido, alguns autores já questionam o termo "mina do futuro" em favorecimento de que já existem as chamadas "minas do futuro". Segundo Jamasmie (2010), operações autônomas já vêm vencendo barreiras na industria mineral, mesmo que ainda existam muitos obstáculos a serem vencidos até que essas operações possam ser amplamente adotadas. 


\subsection{Gestão Operacional e Manutenção de Ativos Físicos}

De acordo com Fulgencio (2007), em contabilidade, "ativo" consiste num termo básico utilizado para expressar o conjunto de bens, valores, créditos, direitos e assemelhados que formam o patrimônio de uma pessoa ou entidade, num determinado momento, avaliado pelos respectivos custos.

O PAS-55 ("Publicly Available Specification") ${ }^{13}$ classifica os ativos em cinco classes distintas: financeiros, intangíveis, físicos, humanos e de informação. No contexto deste trabalho de pesquisa, serão abordados os aspectos referentes aos ativos físicos de mina, especificamente, os equipamentos de lavra.

Quando se fala em gestão de equipamentos em mineração, especificamente em relação aos equipamentos envolvidos nas atividades de lavra, foco principal deste trabalho, deve-se ter em mente que este é um tipo de situação distinta de outros segmentos que utilizam ativos físicos (equipamentos) para a realização das atividades ao longo de sua cadeia de produção.

Por exemplo, considerando o caso de uma companhia que trabalha com a fabricação de um determinado item: neste caso, para a montagem do item a ser produzido há uma série de máquinas com funções específicas alocadas de modo fixo ao longo de uma linha de produção desempenhando, cada uma delas, atividades fixas dentro da cadeia de produção. Nessa situação, a produção segue padrões rígidos e pouco influenciáveis por fatores externos. Desta forma, as equipes de manutenção podem definir com segurança os melhores momentos para a parada dos equipamentos para sua manutenção.

No caso de uma empresa de mineração, entretanto, esta situação não é observada nas atividades de lavra diárias. Neste caso, não são os produtos que se deslocam ao longo de uma linha de produção fixa para serem confeccionados, mas sim são

13 O PAS-55 surgiu em 2004, na Inglaterra, com a necessidade que as empresas tiveram de criar uma forma padronizada e proativa de gerenciar ativos físicos. A união das empresas que fazem parte do instituto IAM ("Institute of Asset Management") e do BSI "British Standards Institute") foi o passo inicial para o desenvolvimento desta especificação. Uma vez lançado este documento público, a meta passou a ser a divulgação da ideia de trabalho organizado e padronizado com estrutura de implementação consistente a empresas do mundo todo. (Fonte: $h$ ttp:///pas55.net) 
transportados juntamente com os próprios equipamentos utilizados na lavra que, para a execução dos serviços, trabalham constantemente expostos a fatores externos como eventos climáticos, estado de conservação das vias de circulação, dentre outros.

Outro ponto de relevância na lavra diz respeito ao layout das operações. Neste caso, não existe a possibilidade de definição de um layout projetado fixo para a produção de minérios; o que ocorre nesta situação é o deslocamento de um conjunto de equipamentos para uma determinada alocação temporária com o objetivo de cumprir uma tarefa, por exemplo, a lavra de minérios numa frente. Uma vez que uma mina possui geralmente mais de uma frente de lavra para atender os requisitos de qualidade exigidos pela unidade de beneficiamento, surge a necessidade de realização de serviços de forma paralela e simultânea, de modo a gerar um produto (no caso o minério) com as características esperadas.

Devido à realização de atividade em frentes de serviço diferentes no mesmo período de tempo, surge a necessidade de definição de um setor dentro das empresas que seja responsável pela distribuição dos equipamentos de forma que sua utilização seja a mais rentável possível, o setor de Gestão de Equipamentos, conforme sugerido por Veloso (2009). A função deste setor será planejar e coordenar a dinâmica de atividades de cada equipamento dentro do layout operacional da empresa.

Dentro de uma empresa de mineração, a área de manutenção representa uma fatia significativa do negócio em termos de movimentação interna de capital, de modo que a utilização racional dos recursos disponíveis terá forte impacto no resultado econômico/financeiro da companhia como um todo. Além da execução e gestão de reparos dos equipamentos envolvidos diretamente nos serviço de lavra, também é comum que sejam realizados serviços auxiliares de acordo com as necessidades que surgem de forma não programada, a citar, por exemplo, itens específicos às centrais de produção.

Portanto, qualquer empresa de mineração que busque resultados satisfatórios em termos de produtividade deve sempre manter os equipamentos utilizados nas atividades dentro de condições adequadas de operação. Desta forma, as empresas 
de mineração devem atender a três princípios básicos relacionados à gestão, utilização e manutenção de seus ativos, que são:

- Os equipamentos de lavra devem estar sempre em plena atividade;

- A gestão dos equipamentos deve ser realizada de forma racional e sempre aprimorada;

- Deve ser definido e implementado um programa efetivo de manutenção dos equipamentos utilizados nas operações.

Dentro desses princípios, a área de equipamentos numa empresa de mineração pode ser subdividida em dois setores conforme sugerido por Veloso (2009):

- Gestão de Equipamentos: responsável pelo atendimento das necessidades da produção com equipamentos apresentando condições satisfatórias de trabalho, cuja alocação seja feita seguindo-se critérios de otimização das operações, de modo a obter melhor produtividade com menor custo;

- Manutenção de Equipamentos: tem como função suprir a demanda por equipamentos nas condições satisfatórias de trabalho esperadas, além de manter sempre em operação os equipamentos que estiverem alocados para a realização de serviços na mina. Também deve atuar de forma a utilizar, da forma mais racional possível, os recursos disponíveis no sentido de aumentar a produtividade de cada equipamento dentro de sua vida útil de operação.

Desta forma, fica clara a importância da área de gestão de equipamentos numa empresa de mineração, de modo a atender os requisitos operacionais particulares desse tipo de empreendimento.

\subsection{1. Áreas Funcionais da Mina e Suas Interações}

A mina é um recurso que faz parte de uma unidade maior do negócio mineral: a própria companhia mineradora. Neste aspecto, a empresa apresenta uma estrutura 
funcional complexa que vai, por exemplo, desde a área de recursos humanos até a área financeira. Com o objetivo focar no problema principal deste trabalho, a gestão otimizada de ativos físicos em minas a céu aberto, será definido a seguir um modelo funcional relacionado apenas às atividades da mina. Neste modelo, serão consideradas três unidades dotadas de mesma posição hierárquica (Figura 21):

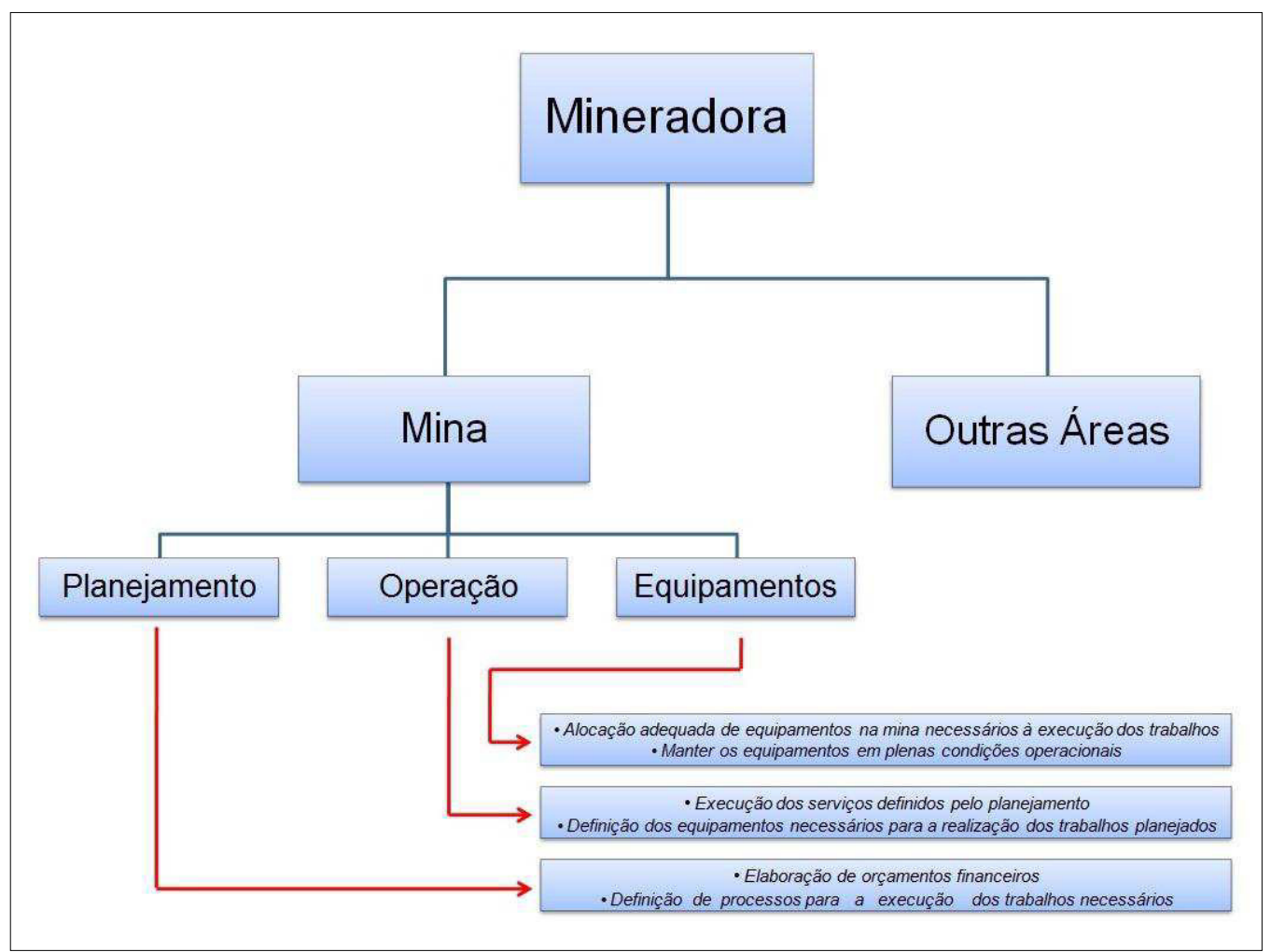

Figura 21 - Estrutura organizacional de uma mineradora. Neste caso, com ênfase à área objeto de estudo deste trabalho: a área de gestão de ativos físicos

(Fonte: Arquivo próprio)

- Planejamento: o planejamento terá como funções a elaboração de orçamentos financeiros e definição de processos para a execução dos trabalhos necessários na mina de forma dinâmica, de acordo com as variações que venham a surgir no cenário do negócio. Em resumo, o planejamento será a área que definirá em que momento serão utilizados os recursos da empresa e, além disso, como estes recursos serão utilizados;

- Operação: a operação (ou produção) será a área responsável pela execução dos serviços definidos pelo planejamento dentro dos limites econômicos e financeiros estabelecidos. Além disso, será responsável também pela 
definição dos equipamentos necessários para a realização dos trabalhos planejados;

- Equipamentos: a área de equipamentos terá como função a alocação adequada de equipamentos na mina necessários à execução dos trabalhos. Estes equipamentos devem estar em plenas condições operacionais, de modo que os serviços sejam executados dentro dos prazos definidos pelo planejamento.

Neste cenário, quanto à sinergia entre as unidades funcionais, pode ocorrer:

- Interação Formal: quando todos os mecanismos de interação entre as unidades funcionais ocorrem de modo formal. Neste caso, há risco de burocracia nos processos de tomada de decisões;

- Interação Informal: quando os mecanismos de interação não seguem qualquer diretriz. Neste caso, a tomada de decisões ocorre de forma isolada e sem critérios definidos;

- Interação Flexível: neste caso, existe uma formalização quanto à formulação dos modelos conceituais e suas normas e, a partir disso, a uma direção flexível quanto à execução do que foi definido. Este costuma ser o tipo de interação proposto pela maioria das empresas de mineração (Figura 22). 


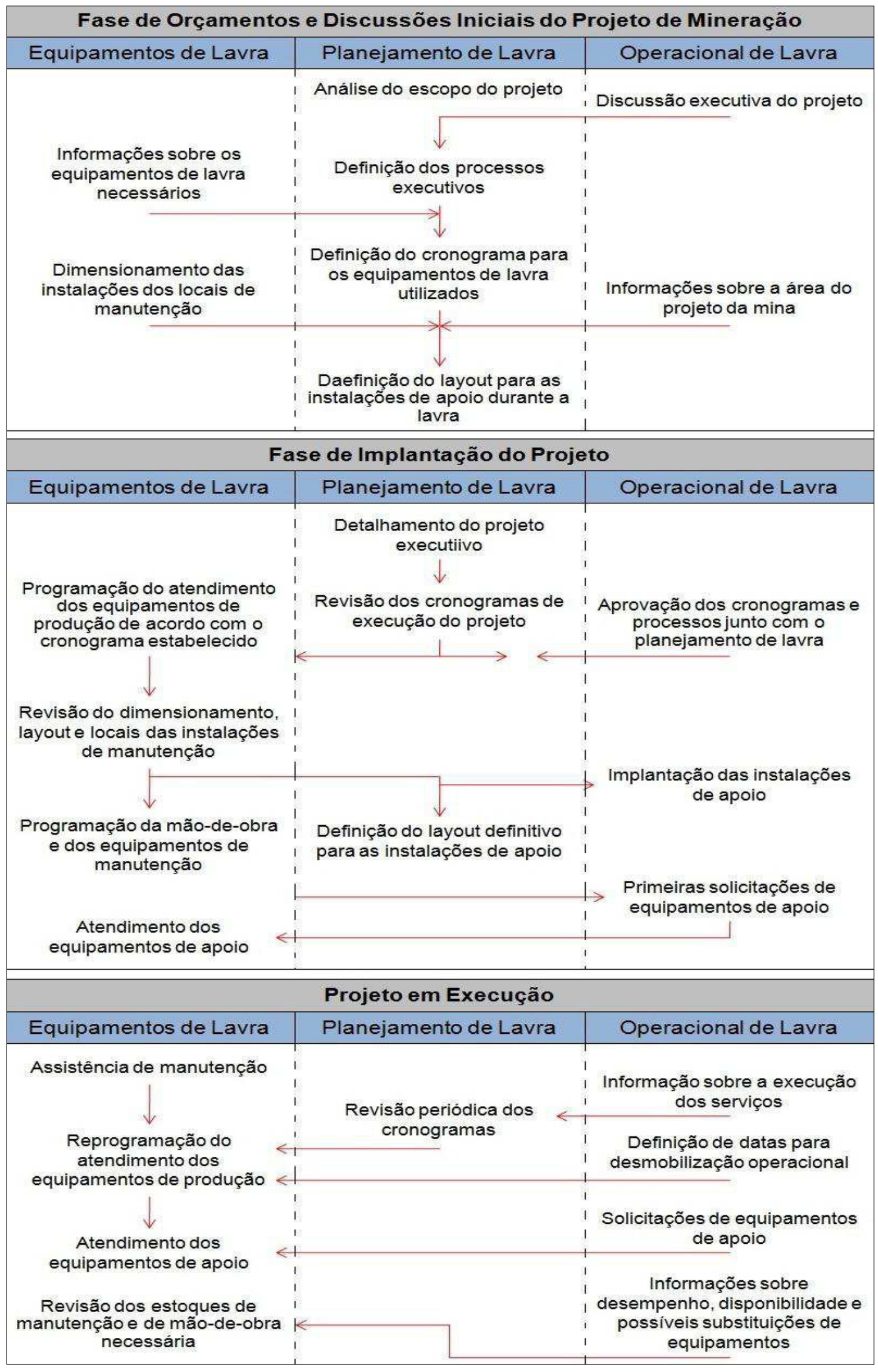

Figura 22 - Mecanismos de interação entre as unidades funcionais numa mina [Fonte: Adaptado, Veloso (2009)] 
Conforme pode ser observado na Figura 23, um projeto de mineração pode ser subdividido em três fases:

- Discussões Iniciais do Projeto: nesta fase, são realizados os primeiros orçamentos do projeto, com o suporte funcional das áreas de Produção e Operação. Neste caso, o Planejamento define as rotas de execução do projeto. Logo a seguir, com o apoio da área de Equipamentos, é feita a revisão das rotas de execução do projeto e definição dos equipamentos necessários. Uma vez tendo à disposição as informações sobre o dimensionamento da frota necessária, o Planejamento define os cronogramas para os diversos equipamentos. Este cronograma será utilizado pela área de Equipamentos para o atendimento e dimensionamento das instalações de suporte para a manutenção. O final desta primeira fase do projeto ocorre quando estão definidos todos os processos licitatórios e contratações necessárias, onde são realizadas revisões detalhadas dos cronogramas de execução e alocações das instalações necessárias, dentre outros;

- Fase de Implantação: a primeira etapa desta fase é preparação das áreas de lavra e das instalações de suporte direto de atividades. Aqui, a área de Equipamentos definirá programação para a mão-de-obra a ser utilizada, os equipamentos necessários de produção e de suporte de manutenção. A área de Operação terá a função de aprovar ou não as requisições feitas pela área de Equipamentos que, uma vez tendo atendida suas solicitações, definirá um plano de atendimento de equipamentos de acordo com calendário programado;

- Fase de Execução: esta fase terá a supervisão direta das áreas de Operação e Planejamento. A Operação fica encarregada da supervisão dos trabalhos realizados em nível de campo, enquanto o Planejamento atua na revisão dos processos e cronogramas do projeto, revisando a programação das atividades a curto e médio prazos. A função da área de Equipamentos nesta fase terá foco no dimensionamento e utilização dos equipamentos necessários. 
Em resumo, durante um projeto de mineração, a área de Planejamento de Lavra terá como função definir as necessidades totais do projeto, sendo a área de Operações a responsável pela execução das atividades planejadas e a área de Equipamentos a responsável pelo atendimento dos requisitos de produção. Mesmo possuindo atribuições distintas, estas três áreas devem atuar de forma conjunta e alinhada aos princípios estratégicos globais da empresa.

\subsection{2. Área de Equipamentos de Lavra}

Uma vez que o foco principal deste trabalho são os ativos físicos de mina, ou seja, os equipamentos utilizados nas atividades de lavra, surge a necessidade de uma descrição mais completa das atribuições da área de Equipamentos de Lavra numa empresa de mineração. As principais são:

- Atender às necessidades de equipamentos de produção e suporte, seja por aquisição, aluguel, dentre outros;

- Executar reformas e revisões dos equipamentos dentro de normas de manutenção programadas;

- Definir contratos de prestação de serviços com prestadores externos, quando necessário, de modo a garantir a disponibilidade de equipamentos de produção;

- Controlar todas as informações referentes à utilização dos equipamentos de lavra, de modo a permitir o controle efetivo dos ativos;

- Determinar a vida útil de cada equipamento, definindo o melhor momento para sua substituição;

- Realizar estudos de viabilidade de utilização de equipamento mais avançados tecnologicamente, modificações e tecnologias de manutenção, dentre outros;

- Controlar os custos de manutenção dos equipamentos de lavra; 
- Realizar a análise econômica contínua para cada equipamento utilizado nas atividades de lavra;

- Desenvolver critérios de padronização de equipamento, de modo a dar suporte à área de Planejamento para definir os meio adequados quanto à aplicação e adequação dos equipamentos de lavra, bem como sua utilização programada;

- Planejar a alocação das unidades de suporte para a instalação de oficinas de manutenção;

- Elaborar planos de manutenção preventiva eficazes, de acordo com a programação da produção da mina;

- Identificar serviços de manutenção terceirizados, quando necessários, e acompanhar as suas atividades;

- Definir os estoques necessários para a manutenção dos equipamentos;

- Gerir a aplicação de normas de segurança relacionadas à utilização dos equipamentos nas diversas atividades da lavra.

As atribuições citadas estão baseadas em duas áreas de gestão distintas: a Gerência de Equipamentos e a Gerência de Manutenção, conforme Veloso (2009). Dentro das atribuições da Gerência de Equipamentos, existirá um Departamento Técnico (responsável por especificações e custos) e um Departamento de Suprimentos de Equipamentos (atendimento de necessidades dos serviços). A Gerência de manutenção será formada por um Departamento de Assistência de Manutenção (interação entre a área de Equipamentos e as frentes de lavra), um Departamento de Manutenção Central (reformas e revisões de equipamentos) e um Departamento de Serviços Externos (coordenação de serviços externos necessários).

A Figura 23 mostra o organograma organizacional proposto. 


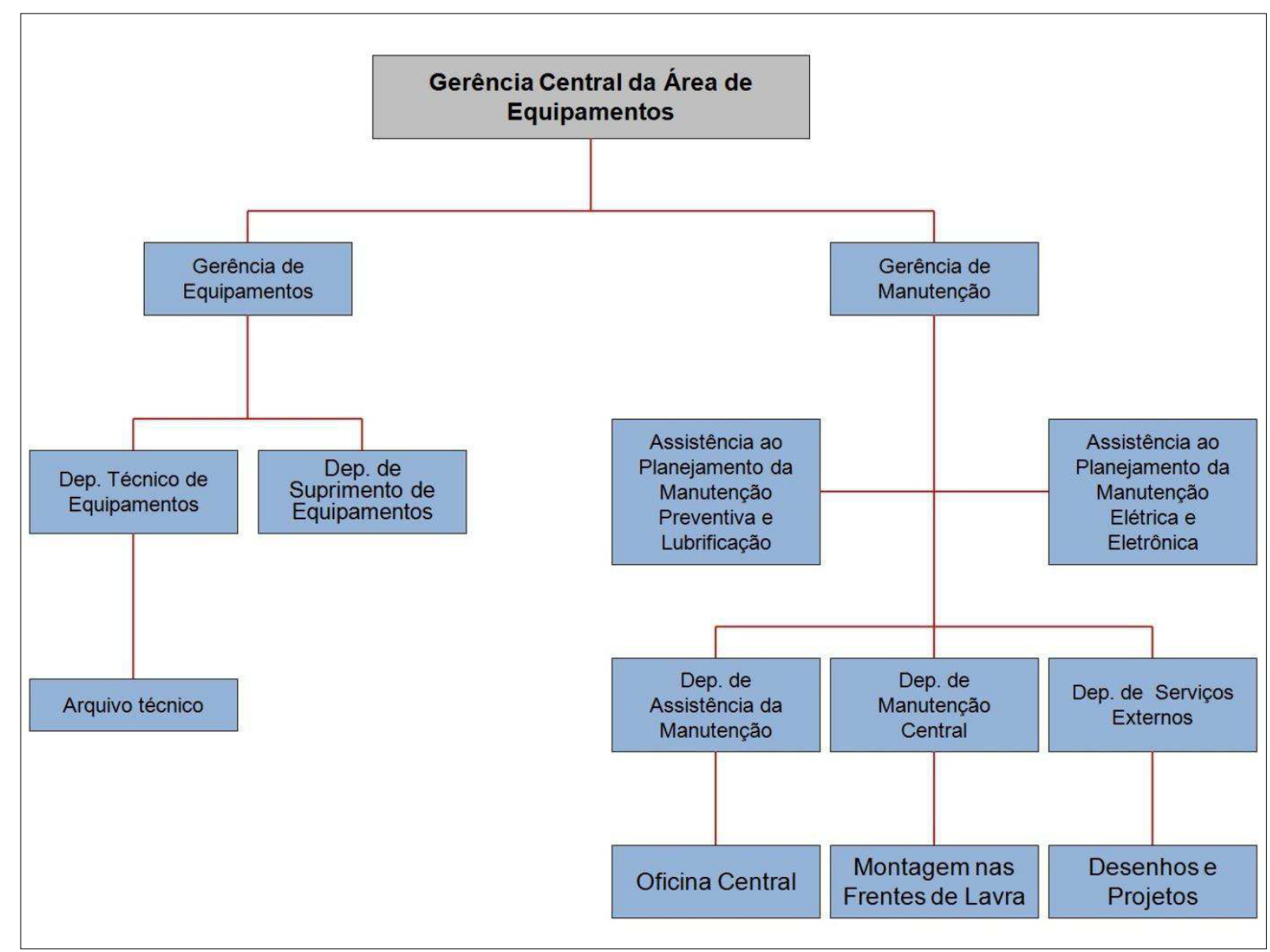

Figura 23 - Organograma organizacional para a área de equipamentos de lavra [Fonte: Adaptado, Veloso (2009)]

\subsubsection{Gestão de Ativos em Empresas de Mineração}

Nas empresas de mineração, os equipamentos de lavra estão sempre se deslocando continuamente nas áreas de atividades cumprindo os seus serviços. Nesse cenário, surge a necessidade de identificar, individualizar e controlar, de forma aprimorada, todas as operações realizadas por esses equipamentos. Neste caso, a área Técnica de Equipamentos será a responsável pela gestão de todos os equipamentos em atividade na lavra, tendo como principais atividades:

- Disponibilizar informações técnicas de cada equipamento em operação para as demais áreas da empresa que necessitem dessas informações; 
- Realizar pesquisas sobre novos tipos de equipamentos que possam ser utilizados nas operações e divulgação dos resultados a outras áreas da empresa, as quais tenham interesse;

- Fazer estudos comparativos de desempenhos sobre diversos tipos de equipamentos a serem utilizados na lavra, com o objetivo de definir parâmetros técnicos para aquisições futuras de equipamentos;

- Realizar contatos com fabricantes, distribuidores e demais empresas que trabalhem com equipamentos de mineração, de modo a estar sempre alinhada com as novas tecnologias que surgirem;

- Estabelecer parâmetros para a padronização dos equipamentos utilizados nas operações de lavra;

- Analisar o desempenho de cada equipamento em operação na mina;

- Desenvolver programas de custos referentes à manutenção dos equipamentos em nível operacional, de modo a gerar dados estatísticos que permitam uma análise econômica de sua utilização;

- Determinação da vida útil de cada equipamento, bem como de seu ponto de substituição, por meio de uma análise econômica e de desempenho, de modo a definir os melhores programas de renovação de frota;

- Desenvolver sistemas de gestão de equipamentos e de manutenção ${ }^{14}$;

- Desenvolver sistemas de processamento de dados que façam a ligação entre a área Equipamentos e a área de Sistemas da empresa, de modo a criar transparência em relação aos trabalhos realizados.

14 O desenvolvimento destes sistemas deve ocorrer em função da qualificação do pessoal envolvido na sua utilização, ou seja, a implantação de sistemas robustos por si só não resolvem o problema de gestão de mina. Portanto, é necessário que haja pessoal técnico hábil a utilizá-lo de forma completa. 


\subsubsection{Atendimento às Frentes de Lavra}

Visando atender às demandas de equipamentos ${ }^{15}$ para a produção, há a necessidade de criação de uma área que dê suporte às frentes de lavra da mina, a Área de Suprimento de Equipamentos, que será composta por:

- Administração: a administração será responsável pela armazenagem, movimentação, e demais cuidados referentes à utilização dos equipamentos de lavra. O corpo de trabalho dessa área deverá ser composto por um elemento de supervisão, pessoal operacional para conservação dos equipamentos e um operador de equipamentos;

- Recebimento e Despacho: terá como funções receber os equipamentos de lavra adquiridos, alocá-los e organizar toda sua literatura técnica. Além disso, será responsável também pelo encaminhamento de vistorias para a área de gerência de manutenção. Ainda deverá ser responsável por outros serviços como solicitações de transporte, emissão de notas fiscais, dentre outros;

- Follow-up: terá como funções encaminhar as requisições de equipamentos realizadas, emitir requisições de equipamentos, fornecer informações que permitam à gerência tomar decisões sobre o atendimento das requisições, emitir guias ou ordens de transferência de equipamentos entre as frentes de lavra (ou entre minas diferentes), realizar o acompanhamento dos equipamentos que estiverem sendo realocados e gerir os prazos de revisão e entregas de equipamentos adquiridos ou alugados;

- Cadastro: o cadastro ${ }^{16}$ será responsável pela atualização das informações cadastrais sobre transferências de equipamentos, atualizações de datas para desmobilização de frota, fornecimento de informações sobre decisões gerenciais e atualização de dados sobre equipamentos adquiridos e vendidos;

$15 \mathrm{O}$ atendimento às demandas por equipamentos para as frentes de lavra pode ocorrer por: remanejamento, aquisição, arrendamento ("leasing"), locação ou subempreitada. Esses procedimentos são esclarecidos de forma detalhada em Veloso (2009).

${ }^{16} \mathrm{O}$ cadastro de equipamentos diz respeito ao registro de todos os equipamentos em operação na mina, identificados de forma individual de acordo com critérios específicos. 
- Vendas: será responsável pela preparação dos processos de venda de equipamentos, coordenação de e liberação dos equipamentos vendidos. Além disso, deve tem como funções a emissão de notas fiscais de venda e realização de baixa física e contábil dos ativos negociados;

- Aquisição, Arrendamento e Locação: terá como funções pesquisas de preço de equipamentos, emissão de pedidos de compra, acompanhamento da entrega de produtos adquiridos, coordenação da logística de equipamentos locados ou arrendados, dentre outros. Estas atividades devem ser realizadas de forma alinhada com a área financeira da empresa;

- Licenciamento: a função dessa área está ligada a todos os procedimentos de licenciamento necessários para a posta-em-atividade regularizada de cada equipamento da mina.

\subsubsection{Especificações dos Equipamentos de Lavra}

A especificação de um equipamento de lavra está fundamentada basicamente e função das características técnicas do equipamento e das características técnicas operacionais da mina, do seu desempenho na realização das atividades e do custo operacional. Além disso, a escolha por um tipo de equipamento também dever levar em conta a versatilidade, os aspectos de padronização de frotas específicos de cada mina e as atualizações tecnológicas disponíveis.

Quando se fala em desempenho de um equipamento em atividade, os resultados apresentados tanto estarão relacionados a aspectos de produtividade $\mathrm{e}$ adequabilidade quanto a aspectos de referentes à eficiência mecânica. Nesse contexto, as empresas costumam utilizar Indicadores-Chave de Desempenho ${ }^{17}$. A Tabela 2 a seguir apresenta os principais indicadores utilizados nas empresas que trabalham com equipamentos.

17 O termo "Índice Indicador de Desempenho" é uma adaptação do termo original em inglês "Key Performance Indicator" (KPI), nomenclatura comumente encontrada em trabalhos técnicos da área de gestão de ativos em mineração. 
Tabela 2: Indicadores de desempenho utilizados por grande parte das empresas que trabalham com equipamentos em suas operações

\section{Indicador Definição Cálculo}

\begin{tabular}{|c|c|c|}
\hline \multirow{2}{*}{$\begin{array}{l}\text { Rendimento } \\
\text { Mecânico }\end{array}$} & \multirow{2}{*}{$\begin{array}{l}\text { Relação entre número de horas } \\
\text { trabalhadas e o número horas em } \\
\text { reparo efetivo }\end{array}$} & Horas Trabalhadas \\
\hline & & $\overline{\text { Horas Trabalhadas + Horas em Reparo Efetivo }}$ \\
\hline \multirow{2}{*}{$\begin{array}{l}\text { Eficiência } \\
\text { Mecânica }\end{array}$} & \multirow{2}{*}{$\begin{array}{l}\text { Relação entre número de horas } \\
\text { trabalhadas e o número de horas } \\
\text { à disposição da manutenção }\end{array}$} & Horas Trabalhadas \\
\hline & & $\overline{\text { Horas Trabalhadas + Horas à Disposição da Manutenção }}$ \\
\hline \multirow{2}{*}{ Utilização } & \multirow{2}{*}{$\begin{array}{l}\text { Relação entre o número de horas } \\
\text { trabalhadas e o número possível } \\
\text { de horas de trabalho }\end{array}$} & Horas Trabalhadas \\
\hline & & $\overline{\text { Horas Possíveis de Trabalho }}$ \\
\hline \multirow{3}{*}{$\begin{array}{l}\text { Custo Horário } \\
\text { Médio de } \\
\text { Manutenção }\end{array}$} & \multirow{3}{*}{$\begin{array}{l}\text { Relação entre a folha de } \\
\text { pagamento do pessoal da } \\
\text { manutenção e o número de } \\
\text { homens/hora efetivamente } \\
\text { trabalhados }\end{array}$} & \\
\hline & & Folha de Pagamento do Pessoal da Manutenção \\
\hline & & 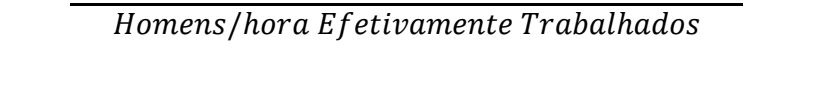 \\
\hline \multirow{2}{*}{$\begin{array}{l}\text { Percentual de } \\
\text { Pessoal }\end{array}$} & \multirow{2}{*}{$\begin{array}{c}\text { Relação entre o número de } \\
\text { homens/hora de manutenção e o } \\
\text { número de homens/hora de } \\
\text { produção }\end{array}$} & Homens/hora de Manutenção \\
\hline & & $\overline{\text { Homens/hora de Produção }}$ \\
\hline \multirow{2}{*}{$\begin{array}{l}\text { Tempo Médio } \\
\text { entre Reparos }\end{array}$} & \multirow{2}{*}{$\begin{array}{c}\text { Relação entre o número de horas } \\
\text { trabalhadas e o número de } \\
\text { paradas para reparo }\end{array}$} & Horas Trabalhadas \\
\hline & & $\overline{\text { Número de Paradas para Reparos }}$ \\
\hline \multirow{2}{*}{$\begin{array}{l}\text { Custo Médio por } \\
\text { Reparo }\end{array}$} & \multirow{2}{*}{$\begin{array}{l}\text { Relação entre o custo total de } \\
\text { manutenção e o número de } \\
\text { paradas para reparos }\end{array}$} & Custo Total de Manutenção \\
\hline & & $\overline{\text { Número de Paradas para Reparos }}$ \\
\hline \multirow{2}{*}{$\begin{array}{l}\text { Espera por } \\
\text { Peças }\end{array}$} & \multirow{2}{*}{$\begin{array}{c}\text { Relação entre o número de horas } \\
\text { paradas à espera de peças e o } \\
\text { número de horas de manutenção } \\
\text { disponíveis }\end{array}$} & Horas paradas à Espera de Peças \\
\hline & & $\overline{\text { Horas de Manutenção Disponíveis }}$ \\
\hline \multirow{2}{*}{$\begin{array}{l}\text { Espera por } \\
\text { Mão-de-obra }\end{array}$} & \multirow{2}{*}{$\begin{array}{c}\text { Relação entre o número de horas } \\
\text { à espera de mão-de-obra e o } \\
\text { número de horas de manutenção } \\
\text { disponíveis }\end{array}$} & Horas paradas à Espera de Mão - de - obra \\
\hline & & Horas de Manutenção Disponíveis \\
\hline
\end{tabular}

[(Fonte: Adaptado, Veloso (2009)]

Os três primeiros índices da tabela acima são básicos para a gestão de ativos da empresa e costumam ser usados em todas as análises referentes aos equipamentos. Em geral, valores entre $60 \%$ e $80 \%$ são considerados satisfatórios e os valores acima de $80 \%$ são tidos como ideais.

Os outros indicadores podem ou não ser utilizados, a depender do porte e do modelo de gestão adotado pela empresa, sendo desenvolvidos para atenderem as 
necessidades específicas de cada mina, frente de lavra ou serviços de suporte das operações diretas de produção.

Conforme citado anteriormente, outro aspecto relevante em relação às especificações de equipamentos é a padronização. As principais vantagens da padronização de equipamentos são a redução de mãos-de-obra específicas para diferentes tipos de equipamentos, redução de estoques variados de peças, possibilidade de aquisição de lotes maiores de peças com as mesmas características, o que permite melhores negociações, dentre outros.

\subsubsection{Análise Econômica e Ponto de Substituição de Equipamentos}

Um dos fatores mais importantes para a análise de desempenho dos equipamentos de mina é, sem dúvida, o seu custo de operação. Devido a variações nas condições operacionais, ora para atender cronogramas pré-estabelecidos, ora para recuperar atrasos ocorridos, os equipamentos de mina são submetidos a esforços além de sua capacidade, o que faz seu custo de manutenção e operação aumentarem. Neste caso, surge a necessidade de realização de uma nova projeção sobre a vida útil de cada equipamento que, geralmente, é determinada com base em condições intermediárias de operação.

Uma vez atuando fora das condições intermediárias de operação indicadas pelo fabricante, cada equipamento necessitará de uma maior assistência da manutenção, o que resultará em aumento de custos para a empresa. Neste item, para a análise de custos do ponto de vista econômico para a substituição de equipamentos, serão abordados dois mecanismos distintos: (i) Métodos Usuais; (ii) Método do Excesso de Despesas.

\section{(i) Métodos Usuais}

A determinação da vida útil dos equipamentos de mina por métodos usuais consiste basicamente na análise dos custos de manutenção e depreciação 
que, neste caso, está relacionada à desvalorização real do equipamento, devido a questões técnicas, de forma independente de aspectos legais.

Neste tipo de análise, com o objetivo de facilitar o trabalho, costumam ser utilizadas funções do tipo linear para prever o valor residual de cada equipamento após determinados períodos de utilização. Entretanto, com o objetivo de gerar resultados mais coerentes, as funções do tipo exponencial são as mais utilizadas, conforme a seguir:

$$
r=e^{-a N}
$$

Onde,

$r \rightarrow$ Valor residual do equipamento após $N$ anos de utilização

$a \rightarrow$ Fator de ajuste de ajuste de curva

$N \rightarrow$ Número de anos de utilização do equipamento

A Figura 24 mostra o gráfico dos custos de equipamentos. Neste caso, podese observar que a depreciação será maior no período inicial e irá se reduzindo gradualmente ao passar do tempo.

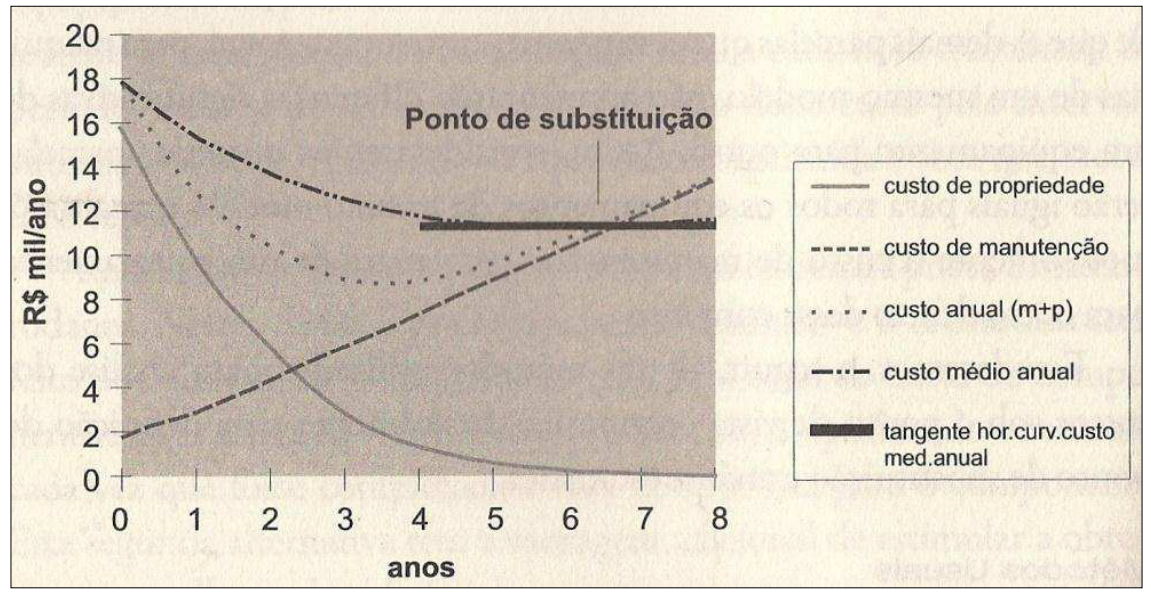

Figura 24: Gráfico dos custos de equipamentos

[Fonte: Veloso (2009)]

Neste caso, para o cálculo do ponto de substituição de cada equipamento, a empresa deverá tomar como padrão o custo médio anual, que corresponde à média anual dos custos de manutenção e depreciação. 
Existem ainda outros métodos que fazem análises referentes a custos anuais globais, que fazem uma estimativa sobre o momento ótimo de substituição de cada equipamento a partir de seu custo total de propriedade. Neste tipo de análise, devem ser levados em consideração:

- Depreciação Anual: costuma ser utilizada a desvalorização de mercado de cada equipamento, após a dedução de juros e da depreciação;

- Juros ${ }^{18}$ : assim como seguros e encargos, são calculados a partir de uma taxa inicial pré-estabelecida, sobre o valor médio anual;

- Manutenção: segundo Veloso (2009), devem ser utilizados os custos registrados de cada equipamento, considerando todas as variações decorrentes do cenário operacional. Neste caso, devem ser considerados todos os serviços, desde aqueles executados com recursos da própria empresa de mineração até aqueles executados por empresas terceirizadas. Os custos de cada um dos serviços executados deve ser reajustado com base em índices anuais específicos de acordo com o segmento de mercado;

- Outros Custos: estão relacionados tanto a fatores diretos de operação dos equipamentos quanto a fatores indiretos, tais como: combustível, salários de operadores de cada equipamento, impostos, dentre outros.

\section{(ii) Método do Excesso de Despesas}

A partir da análise dos métodos usuais sobre o ponto de substituição de equipamentos, se percebe que os cálculos dos custos são baseados sempre

${ }^{18} \mathbf{V}=\frac{\mathbf{I}-\mathbf{F}}{2}$

Onde,

I e F $\rightarrow$ Valor de mercado do equipamento no início e final do ano considerado. 
em períodos de tempo fixos, anuais ou mensais, por exemplo. Entretanto, esta não é uma das abordagens mais adequadas para o tratamento do problema, pois no caso de equipamentos de mina, principalmente aqueles ligados diretamente às atividades de lavra, o fator mais relevante para a determinação dos custos operacionais são as horas trabalhadas.

Durante as operações de lavra, os equipamentos são submetidos a diferentes condições de operações. Desta forma, é comum que se tenham diferentes custos operacionais, por exemplo, para equipamentos do mesmo tipo e adquiridos na mesma época. Portanto, a simples utilização de parâmetros temporais não se justifica como alternativa efetiva para análise de custos. Desta forma, se recomenda que as empresas de mineração adotem sempre como referência para o cálculo do custo operacional de cada equipamento o número de horas trabalhadas. Outra vantagem da utilização das horas trabalhadas consiste na possibilidade de mapear a produtividade de cada equipamento de lavra.

Este tipo de análise envolve as seguintes etapas subsequentes:

- Análise dos custos de manutenção de cada equipamento envolvido nas atividades de lavra. Estes custos devem ser analisados segundo períodos de 1000 (mil) horas trabalhadas ou 30000 (trinta mil) quilômetros rodados;

- Determinação dos parâmetros médios de custos e tempo de trabalho necessário à manutenção ${ }^{19}$, agrupados mais uma vez, em intervalos de 1000 (mil) horas ou 30000 (trinta mil) quilômetros rodados;

- Definição de um parâmetro que represente a vida útil média de cada equipamento da mina. A definição deste parâmetro pode ser baseada em horas trabalhadas ou quilômetros rodados, de acordo com os critérios mais adequados a cada empresa;

${ }^{19}$ Os parâmetros médios de custos e tempo de trabalho podem ser determinados com base, por exemplo, em dados do fabricante ou em históricos da própria empresa de mineração. 
- Uma vez definido o parâmetro de cada equipamento de lavra, deve ser feita uma comparação entre o valor calculado e o valor observado por equipamento, com o objetivo de quantificar o excesso de despesas;

- Análise dos resultados observados, com o objetivo de estabelecer cenários que permitam tomadas de decisões mais confiáveis quanto à alocação de recursos para a manutenção dos equipamentos de lavra.

\subsection{PDCA}

\subsubsection{Histórico}

De acordo com WERKEMA (1995b), as primeiras referências ao controle de qualidade em processos datam dos anos 30 , com a implementação industrial do gráfico de Walter A. Shewart, na empresa Bell Telephone Laboratories ${ }^{20}$.

Com o objetivo de atender à grande demanda do esforço de guerra americano durante a Segunda Guerra Mundial, a utilização do controle de qualidade por grande parte das empresas possibilitou a produção de itens militares de qualidade em grande quantidade.

Após a derrota dos japoneses, no Pacífico, as tropas americanas de ocupação que chegaram ao país enfrentaram grandes dificuldades de comunicação. Desta forma, solucionar este problema foi uma prioridade vital. A solução foi implantar um sistema de controle de qualidade no sistema de comunicação telefônica japonês. Para isto, foi criada a $J U S E^{21}$ e, ao ano de 1950, a JUSE organizou um seminário ministrado pelo estatístico William Edwards Deming, cujo tema foi o controle de qualidade para administradores e engenheiros.

20 A Bell Telephone Laboratories era o departamento de pesquisa e desenvolvimento da AT\&T dos Estados Unidos, que desenvolvia tecnologias nas áreas de telefonia, lasers, linguagem de programação C e o sistema Unix, entre outros.

21 A JUSE (Union of Japanese Scientists end Engineers) foi uma organização formada por engenheiros e pesquisados no Japão pós-Segunda Guerra mundial, com o objetivo de implementar o controle de qualidade nas indústria japonesas. 


\subsubsection{Definições do PDCA}

De acordo com Godoy (2010), o ciclo PDCA consiste em uma sequência de procedimentos utilizados para controlar qualquer processo definido, servindo como uma ferramenta que auxilia na organização do processo de implementação de melhorias, dando uma diretriz para a condução de projetos / processos. Além disso, o PDCA também pode ser utilizado para o planejamento de testes para obtenção de informações a respeito de um processo, antes da implementação de uma melhoria.

Segundo ISHIKAWA $(1989,1993)$ e CAMPOS $(1992,1994)$, o ciclo PDCA é composto por quatro etapas: Plan (Planejar), Do (Agir/Atuar), Check (Verificar) e Action (Atuar corretivamente).

A Figura 25 ilustra as etapas do ciclo PDCA.

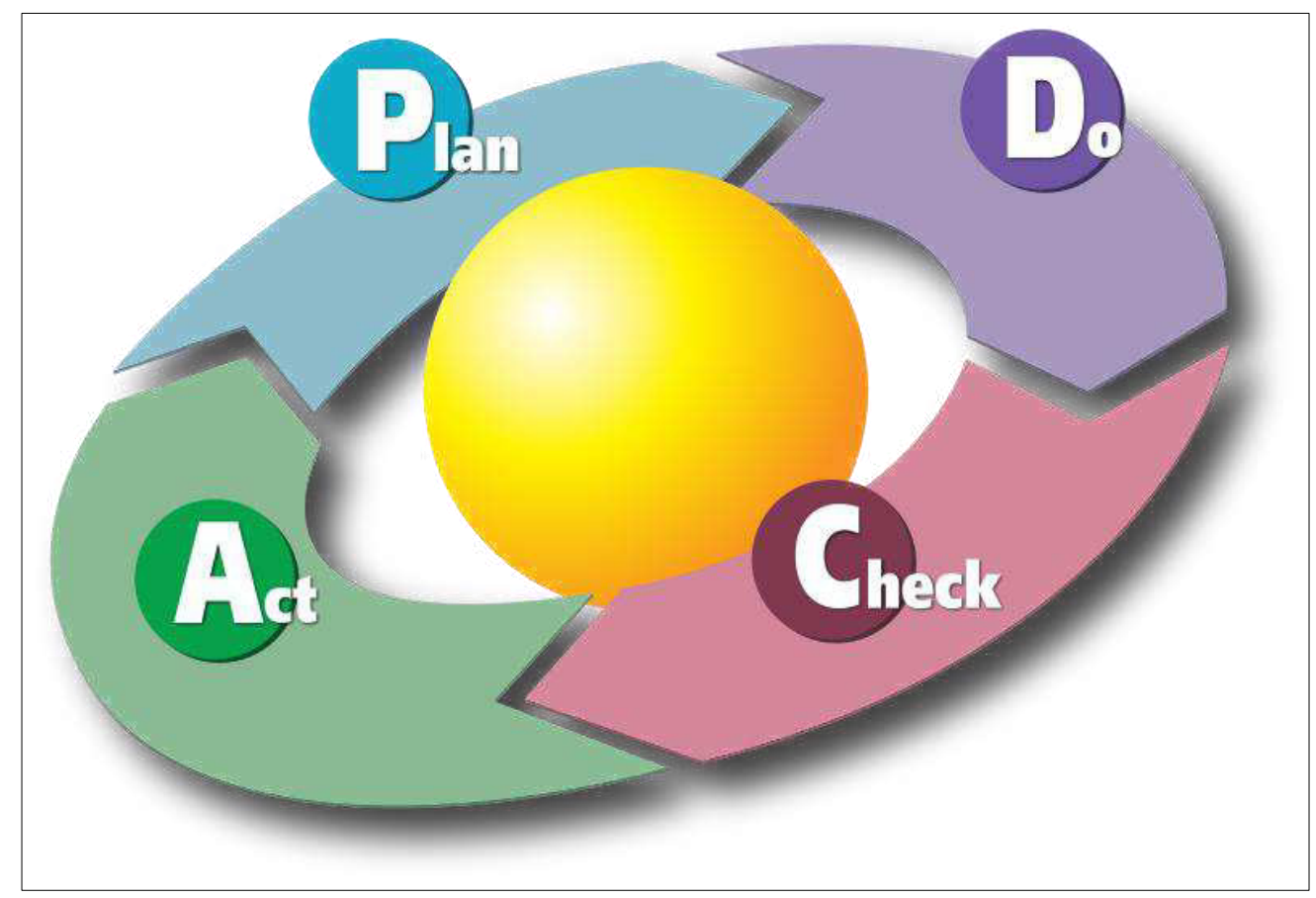

Figura 25: Etapas do ciclo PDCA

(Fonte: $h$ ttp://fastsolucoes.com.br/blog/?p=620)

De acordo com os autores citados, as definições de cada etapa do ciclo PDCA são:

- Plan: estabelecimento de metas e métodos para que os resultados esperados sejam alcançados; 
- Do: execução de tarefas conforme o que foi planejado na etapa de planejamento (Plan) e coleta de resultados a serem utilizados na etapa seguinte do ciclo. Nesta etapa, trabalhos de treinamento e capacitação de equipes são fundamentais;

- Check: comparação dos resultados alcançados (por meio dos dados coletados na etapa " $D o$ ") em relação às metas estabelecidas;

- Act: atuação no processo de acordo com os resultados obtidos obedecendo o plano de ações proposto.

\subsubsection{PDCA Como Ferramenta de Melhoria Contínua}

De acordo com WERKEMA (1995b), quanto ao PDCA como ciclo de melhoria contínua, devem ser feitas as seguintes observações quanto às suas etapas:

\section{Planejamento:}

Identificação do problema e de acordo com uma meta de melhoria. Nesta etapa, podem ocorrer duas situações distintas: Meta ruim - surge a partir de um plano estratégico e é baseada nas restrições de mercado e nas necessidades da empresa e; Meta boa - surge a partir de anomalias da própria empresa.

Após a etapa "P", deve ser realizada uma análise do problema, de modo a se conhecer as suas características específicas, de modo localizar os seus pontos focais.

A seguir, deve-se fazer o reconhecimento das causas fundamentais do problema e estabelecer um plano de ação por meio, por exemplo, dos " $5 \mathrm{~W} 2 \mathrm{H}^{22 "}$.

22 "5W2H" - O que ("What") será feito, quando ("When") será feito, quem (“Who") fará, onde ("Where") será feito, Por que ("Why") será feito e Como ("How") será feito e qual será o custo ("How Much"). 


\section{Execução:}

Esta etapa do PDCA consiste no treinamento e capacitação dos membros da empresa de acordo com as tarefas estabelecidas num plano de ação para a posterior execução destas tarefas e coleta de informações que serão utilizadas posteriormente para avaliação da efetividade das ações realizadas.

3. Verificação:

Nesta etapa será verificada a efetividade das ações adotadas. Se os resultados não forem satisfatórios, volta-se à fase de observação do problema, faz-se uma nova análise e elabora-se um novo plano de ação e, finalmente, gera-se o chamado "Relatório das Três Gerações", o qual deve mostrar: (i) $\mathrm{O}$ que foi planejado; (ii) $\mathrm{O}$ que foi executado; (iii) Os resultados obtidos.

\section{Atuação Corretiva:}

Esta etapa consiste na adoção das ações que foram efetivas, ou seja, aquelas cujos resultados de implementação se mostraram de acordo com as metas estabelecidas. Em relação ao atingimento de metas estabelecidas, o PDCA pode contribuir de duas formas distintas: melhoria contínua, onde se fazer modificações sucessivas em processos existentes; definição de um novo processo, onde se utilizam outros processos mais adequados às necessidades. 


\section{MATERIAIS E MÉTODOS}

Com base nos aspectos relacionados ao tema deste trabalho, a gestão operacional de minas a céu aberto, foi realizada a formalização do modelo PDCA 90-10 de gestão operacional de mina, modelo este que surgiu de maneira prática quando implementado inicialmente numa mina de fosfato localizada no interior do Estado de Minas Gerais - Brasil, conforme explicado nos itens que se seguem. A fase seguinte do trabalho foi realizada de forma prática junto à empresa parceira do projeto, a VALE, com o estudo do modelo de gestão utilizado em uma de suas unidades operacionais no Brasil (mina de Sossego, Pará). Em seguida, foram sugeridas melhorias ao modelo de gestão utilizado pela empresa, melhorias estas com base nos conceitos fundamentais do modelo PDCA 90-10. Como resultado, foi obtido um modelo aprimorado de gestão para a mina onde foram realizados os estudos (ver item "Resultados").

A Figura 26 apresenta a metodologia seguida para a realização deste trabalho, a qual é detalhada nos itens que se seguem.

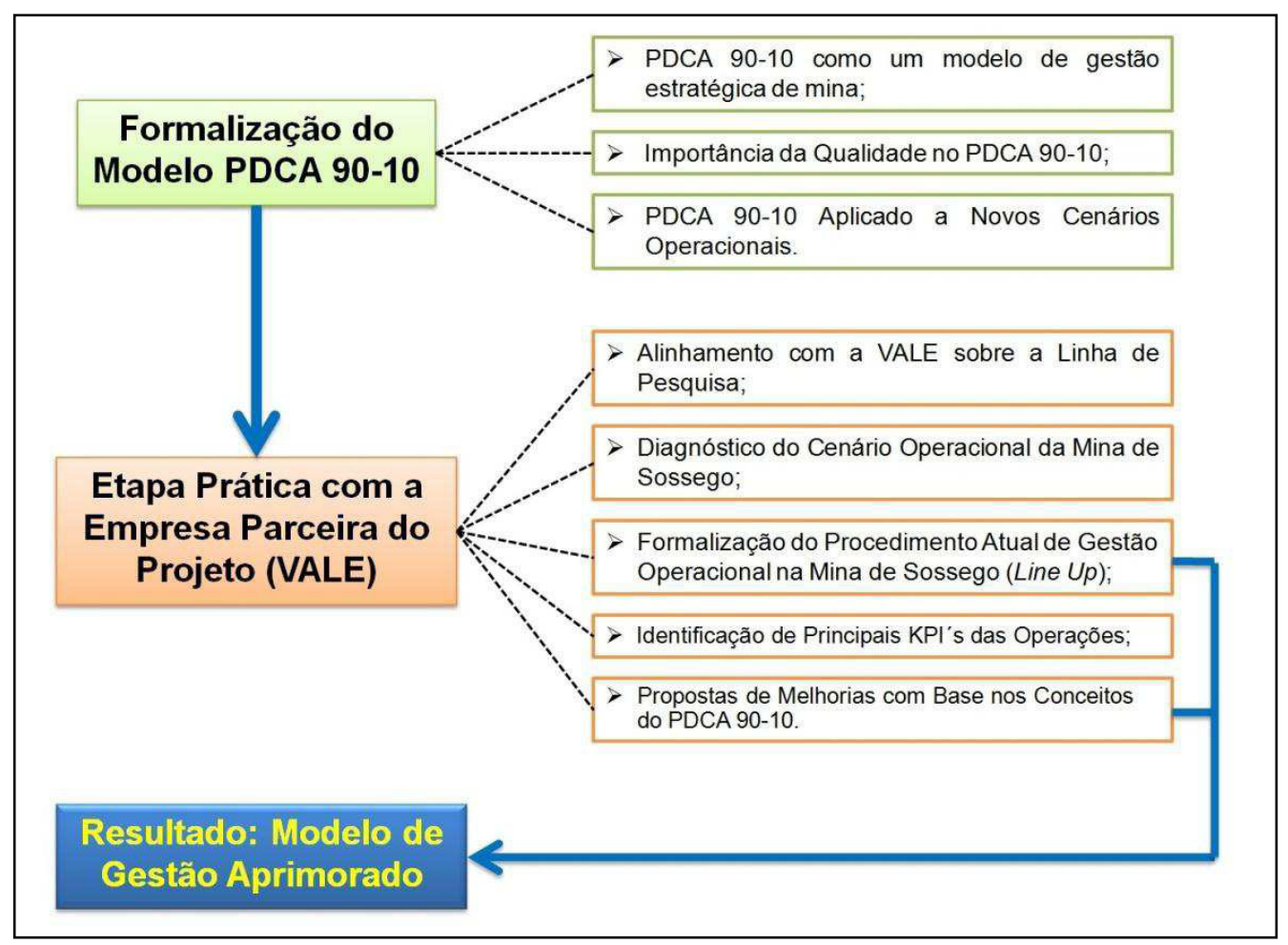

Figura 26 - Metodologia para realização do trabalho

(Fonte: Arquivo próprio) 


\subsection{Formalização do Modelo PDCA 90-10}

Um dos maiores desafios para a gestão de mina consiste no controle dos planos de ações estabelecidos, a citar, por exemplo, o modelo PDCA $^{23}$ de atividades. Neste aspecto, o uso de Tecnologia da Informação (TI) surge como requisito básico para a gestão aprimorada de mina, gerando controles mais efetivos das operações, maior confiabilidade quanto à execução das atividades planejadas e, além disso, maior segurança para a circulação e utilização das informações em todo o cenário operacional.

Conforme citado a priori, a utilização de TI tem papel fundamental na gestão de mina. Entretanto, a implantação de sistemas robustos por si só não garantem um bom rendimento nas atividades operacionais. Neste caso, há a necessidade de implantação de unidades de controle de operações em campo na mina. Um exemplo de ações deste tipo é o modelo 90-10 de gestão, onde $90 \%$ do trabalho de gestão operacional deve ser realizado em campo e $10 \%$ em salas de controle centrais. Este modelo deixa claro o nível de importância da utilização de mecanismos de controle nos serviços de rotina para qualquer empresa de mineração que busque otimizar suas atividades por meio da utilização mais eficiente de seus recursos disponíveis.

A utilização de TI permite que o trabalho de campo seja mais constante, reduzindo a probabilidade de erros nas operações. Desta forma, a equipe de campo deve ter uma área responsável pela disponibilização das informações (conforme explicado anteriormente neste trabalho) definindo e esclarecendo o rumo das decisões tomadas, de modo que a equipe operacional esteja ciente sobre as informações que necessita para os trabalhos diários na mina. Neste aspecto, é válido sempre lembrar que variáveis fiscais, contábeis e legais devem sempre fazer parte do banco de informações das operações.

23 De acordo com Godoy (2010), o ciclo PDCA consiste em uma sequência de procedimentos utilizados para controlar qualquer processo definido, servindo como uma ferramenta que auxilia na organização do processo de implementação de melhorias, dando uma diretriz para a condução de tais projetos / processo. Além disso, o PDCA também pode ser utilizado para o planejamento de testes para obtenção de informações a respeito de um processo, antes da implementação de uma melhoria. 
Portanto, num trabalho de gestão de ativos, modelos de gestão do tipo 90-10 podem ser considerados como exemplos de relevância, de modo que se tenha a operacionalização aprimorada na rotina da mina.

Tomando como base um modelo 90-10 de gestão operacional de mina e controle de ativos, alguns pontos de oportunidade de ganho no desempenho das operações de manutenção são:

- Gestão de Manutenção Preditiva On-line: por meio de dispositivos como os sensores digitais de vibração, temperatura, pressão e consumo de energia e sistemas de transmissão de dados, as informações podem ser adquiridas automaticamente nos equipamentos de lavra em tempo real e transmitidas para uma central de controle, de modo que sejam processadas com ferramentas de gestão de mina apropriadas, com o objetivo de identificar, de forma antecipada, desvios nos padrões normais de operação de cada equipamento e, além disso, definir o momento ideal para a correção do problema;

- Integração com Dados Operacionais: muitas vezes, um problema de manutenção não está associado à quebra propriamente dita do equipamento, mas sim à perda produtividade. Em uma situação onde haja a quebra propriamente dita ou desgaste prematuro de um determinado componente do equipamento, a responsabilidade pode não ser totalmente da manutenção, mas também de uma operação inadequada, que pode ser devida à falta de capacitação da mão-de-obra, por exemplo. Neste sentido, a utilização de um sistema de manutenção preditiva com uma base de dados operacionais integrada serve como um ponto de partida para a identificação de pontos de oportunidade de ganho na operação.

A Figura 27 apresenta o esquema geral de um modelo 90-10 de gestão operacional de mina e manutenção de ativos. 


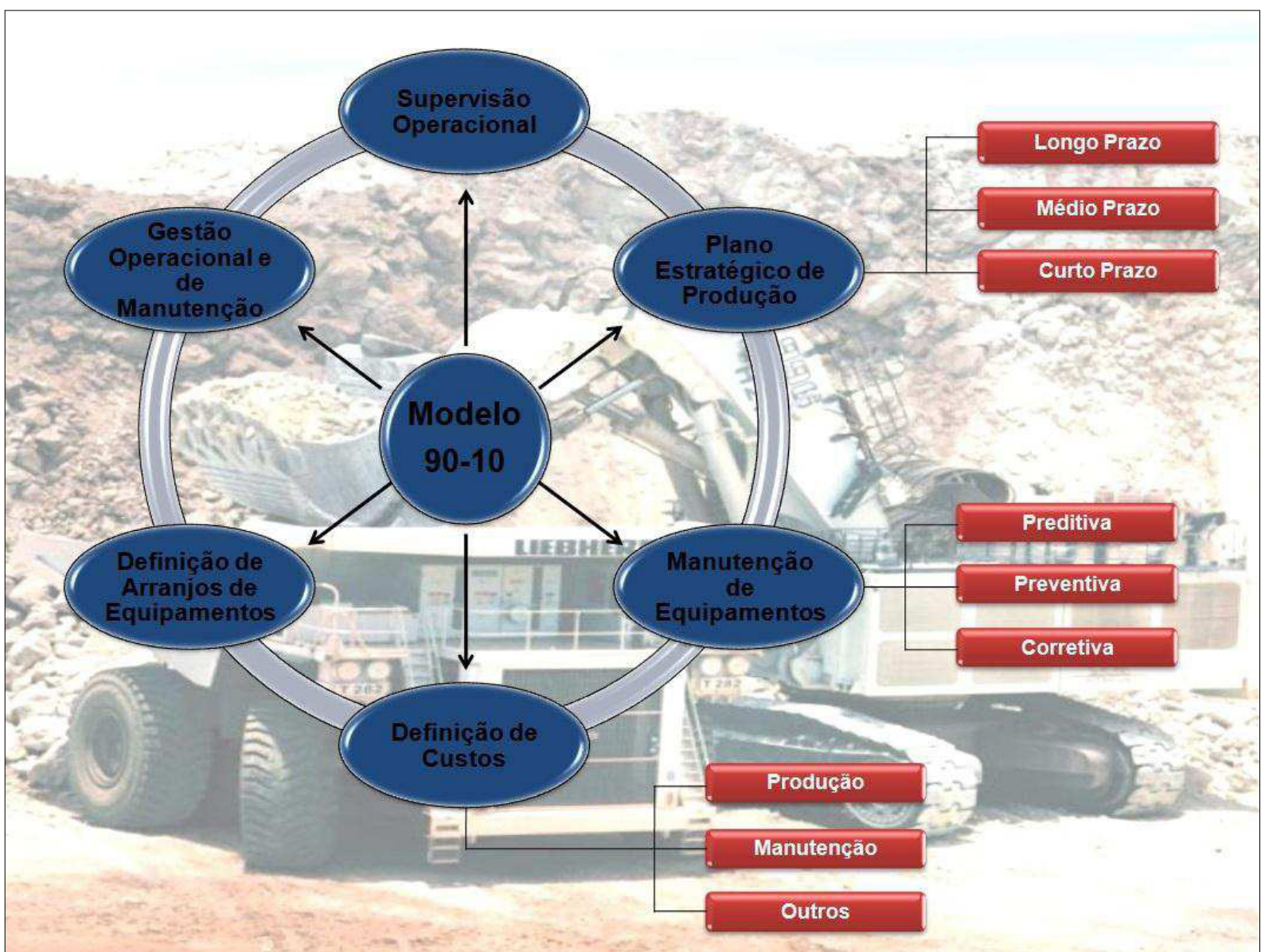

Figura 27 - Esquema geral de um modelo 90-10 de gestão operacional de mina e manutenção de equipamentos de lavra

(Fonte: Arquivo próprio)

\subsubsection{PDCA 90-10 Como Modelo de Gestão Estratégica de Mina}

O conceito "PDCA 90-10" surgiu quando o Engenheiro de Minas Afonso Heraldo Petta ${ }^{24}$ implementou no setor de mineração uma mina de fosfato localizada em Araxá - MG, distante cerca de 360 km de Belo Horizonte - MG, um modelo focado no controle das operações em campo. Uma vez avaliados os resultados da implementação deste modelo de gestão, ficou claro o nível de importância de sua formalização para possíveis replicações posteriores. Outra contribuição importante

${ }^{24}$ Afonso Heraldo Petta: foi gerente de mineração, britagens e manutenção da Arafértil SA. No Grupo Rio Tinto, foi gerente de mineração (Mineração Serra da Fortaleza) e gerente de produção (Mineração Corumbaense Reunidas SA). Na Bunge Fertilizantes SA, foi chefe de operação e planejamento de lavra e chefe de operação de usina de beneficiamento. Foi gerente de mina na Yamana Gold e gerente de produção na Itafos Mineração Ltda. Possui longo histórico na área de gestão empresarial, com MBA Fundação Getúlio Vargas. 
para a formalização do modelo PDCA 90-10 surgiu por meio de conversas com o Engenheiro Geólogo Alexandre Orlandi Passos ${ }^{25}$, o qual, com sua larga experiência no setor de mineração, ajudou a definir os pontos mais relevantes para uma gestão racional de mina.

Um modelo estratégico de gestão deve ser uma ferramenta direcionada para as áreas funcionais e táticas da mineração, dentro de um ciclo PDCA, cuja finalidade seja conduzir as equipes de forma alinhada aos objetivos da mina. Para isso, é importante que todos os objetivos estratégicos sejam considerados logo na fase de planejamento que, por sua vez, também irá adquirir atributos estratégicos, uma vez que além de definir todo um modelo e sequência de operações para a lavra, deverá também integrar toda a cadeia de atividades posteriores, o que permite um processo de controle desde a mina até a usina.

Neste aspecto, uma gestão estratégica que siga os padrões do Modelo PDCA 90-10 surge como uma possível solução para a problemática do gerenciamento operacional de mina. Neste sentido, o ponto focal deste modelo de gestão deverá ser a disponibilização de informações confiáveis à toda equipe envolvida na operação da mina (planejamento, operação direta de lavra, serviços auxiliares de infraestrutura e manutenção) em tempo real, que permita a atuação contínua e direta dos gestores junto ao pessoal de campo, com o objetivo de fazer com que todas as ações sejam executadas conforme estabelecidas, de modo que os desvios ocorridos possam ser identificados e geridos de acordo com seus resultados e as devidas responsabilidades.

As atividades de uma empresa mineradora abrangem, por exemplo, as áreas de operação, planejamento e geologia, dentre outras. Conforme citado anteriormente,

25 Alexandre Orlandi Passos: foi analista de sistemas, chefe de equipe de sísmica da TBG na Amazônia. Foi também geólogo, coordenador regional de mineração, gerente de fábrica e gerente operacional de mineração no Brasil da Votorantim Cimentos e líder da equipe de mineração do Sistema de Gestão Votorantim (VPAR). Possui perfil profissional com mais 20 anos de experiência nas áreas industrial e de mineração, com atuação local e corporativa, estruturando áreas, sistematizando processos e definindo estratégias e diretrizes operacionais, com elevado foco em resultado e pessoas. Atualmente, atua como diretor da i9 Tecnologia, empresa de consultoria focada em desenvolvimento tecnológico aplicado, onde além de desenvolver projetos próprios, apoia outras empresas na estruturação de setores de P\&D utilizando linhas de financiamento com juros reduzidos e incentivos fiscais. 
este trabalho aborda apenas a área de lavra, com a implantação de um modelo PDCA 90-10 de gestão das operações de mina. Desta forma, o principal objetivo consiste na demonstração da importância da introdução dos conceitos de estratégia nas operações de lavra das empresas, modelo este que pode ser aplicável (com eventuais ajustes) a qualquer outro projeto de mineração do mundo.

Neste sentido, qualquer proposta de melhorias em um processo deve ser iniciado por um mapeamento estratégico global. Neste sentido, existem diferentes tipos de abordagem a ser adotada. No caso específico considerado, a metodologia proposta por Marcelli (2000), a qual divide um mapeamento estratégico em cinco fases, foi adaptada para o cenário específico da mineração, conforme os itens que se seguem.

- Organização Orientada ao Aprimoramento das Operações de Lavra: (1) Definição dos processos de lavra; (2) Seleção dos "donos" de cada processo de lavra; (3) Definição das restrições de cada processo de lavra; (4) Estabelecimento dos KPl's críticos dos processos de lavra; (5) Estabelecimento de um banco de dados geral das operações de lavra;

- Entendimento do Processo de Lavra: (1) Elaboração de fluxograma das operações de lavra e cominuição; (2) Identificação dos pontos críticos das operações de lavra; (3) Preparação de um modelo preliminar de simulação de operações; (4) Levantamento das condições de aplicação do simulador nas operações; (5) Realização de testes práticos do modelo de simulação desenvolvido; (6) Acompanhamento dos testes práticos; (7) Avaliação dos resultados das simulações; (8) Ajustes no modelo de simulação;

- Reformulação das Operações de Lavra: (1) Reformulação das operações de lavra com base nos resultados da simulação; (2) Implantação prática das reformulações necessárias às operações de lavra; (3) Acompanhamento do desempenho operacional da mina; (4) Avaliação dos resultados práticos obtidos; (5) Validação das medidas de reformulação;

- Implementação de Medidas Estabelecidas nas Operações de Lavra: (1) Finalização do plano de posta em prática das reformulações validadas; (2) 
Implementação prática nas operações de lavra; (3) Acompanhamento do cenário de lavra; (4) Definição de mecanismos de feedback para as operações de lavra; (5) Avaliação de custos de qualidade das reformulações implementadas;

- Melhoria Contínua do Processo de Lavra: (1) Acompanhamento das operações continuamente em campo; (2) Avaliação contínua dos resultados das operações; (3) Planejamento de ações corretivas e/ou melhorias; (4) Execução prática das ações planejadas.

A Figura 28 mostra a metodologia de Marcelli (2000) para o mapeamento estratégico de processos, adaptada ao cenário da mineração para o exemplo de aplicação apresentado.

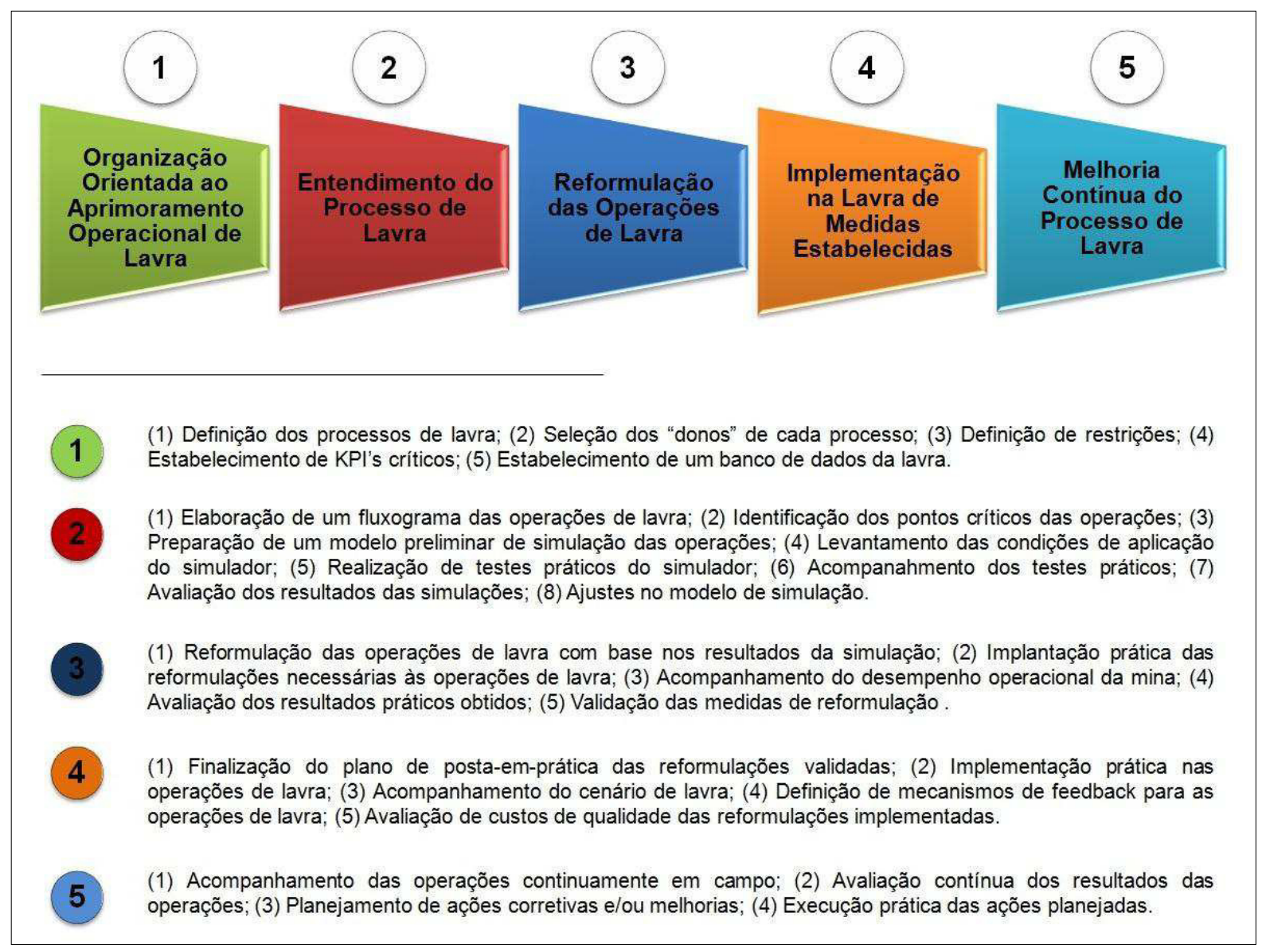

Figura 28: Mapeamento estratégico de processos, com base na adaptação da metodologia de Marcelli (2000)

(Fonte: Arquivo próprio) 
Portanto, por meio do mapeamento estratégico do processo produtivo e da integração de toda a cadeia de eventos que liga ações executadas, resultados da execução e responsabilidades atribuídas, o processo de gestão de mina pode ser classificado como uma gestão operacional estratégica.

\subsubsection{Importância da Qualidade no PDCA $90-10$}

Qualquer empresa de mineração que busque uma gestão otimizada de seus ativos físicos de mina deve sempre instituir um modelo de qualidade que permita o controle transparente e sistemático de todas as operações realizadas na lavra. Neste aspecto, os princípios básicos para a qualidade ${ }^{26}$ na gestão operacional de mina são:

- Foco no cliente: todas as operações de lavra devem ser realizadas de maneira a atender as necessidades dos clientes nas etapas subsequentes das operações. Neste caso, a denominação "cliente" se refere à unidade operacional que dependerá, em seguida, do trabalho de outra unidade operacional realizado anteriormente;

- Liderança: os gestores de mina devem estabelecer o rumo para as atividades a serem realizadas, mantendo todas as unidades funcionais integradas e alinhadas a um objetivo comum;

- Processo Produtivo: os resultados das operações da mina são alcançados como maior facilidade quando a empresa adota uma política de gerenciamento de produção por processo;

- Sistemática de Abordagem da Gestão: a gestão integrada de todos os processos de produção da mina contribui, de maneira positiva, para eficácia e eficiência do sistema produtivo;

${ }^{26}$ Estes princípios básicos foram baseados na norma NBR ISO 9000 (Sistemas de gestão da qualidade - Fundamentos - vocabulários). 
- Melhoria Contínua: as operações de lavra devem ser conduzidas com foco na melhoria contínua. Como exemplo de modelo de gestão com foco na melhoria contínua das operações, pode ser citado o modelo PDCA de gestão;

- Decisões Baseadas em Fatos: todas as decisões gerenciais tomadas em relação à mina devem ser baseadas na análise dos dados e informações da lavra;

- Relação com Fornecedores: o funcionamento de uma mina implicará sempre na utilização de recursos, os quais nem sempre a empresa terá à disposição nos seus estoques, a citar, por exemplo, peças reposição, itens de utilização comum, dentre outros. Neste aspecto, um bom relacionamento com todos os fornecedores de equipamentos e produtos utilizados nas operações diárias é de fundamental importância para o desempenho da mina e, por consequência, da empresa como um todo.

A Figura 29 mostra o agrupamento dos princípios básicos para a qualidade na gestão operacional de mina.

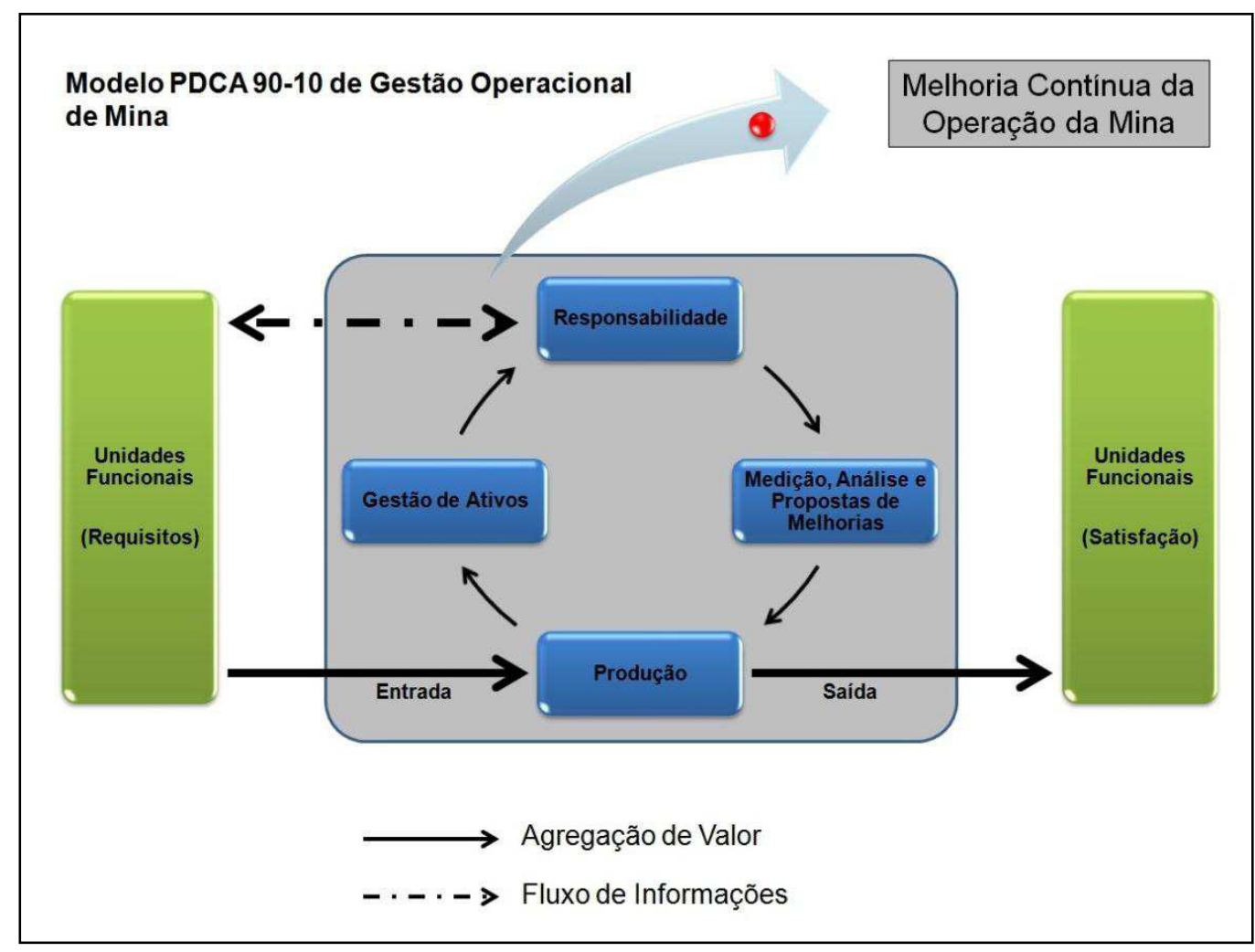

Figura 29 - Princípios básicos da qualidade na gestão operacional de mina

(Fonte: Adaptado, NBR ISO 9000) 
Portanto, a principal função dos gestores de mina deverá ser a criação e implantação de um ambiente no qual todas as unidades funcionais estejam alinhadas aos princípios de governança global no desempenho de suas atividades diárias, de modo que a utilização dos recursos disponíveis seja feita de forma racional e orientada ao seu aproveitamento máximo.

\subsubsection{PDCA 90-10 Aplicado a Novos Cenários Operacionais}

Conforme citado a priori, o modelo PDCA 90-10 de gestão operacional de minas a céu aberto surgiu de maneira prática quando implementado inicialmente numa mina de fosfato localizada no interior do Estado de Minas Gerais - Brasil. Com base nos resultados obtidos por meio da implementação deste modelo, percebeu-se o seu potencial de replicação para outros cenários de mineração a céu aberto.

Desta forma, com o objetivo de avaliar o modelo PDCA 90-10, foi realizado um trabalho junto à mina de Sossego, localizada próxima à cidade de Canaã dos Carajás - PA (Figura 30), distante cerca de 760 Km da Capital do Estado, Belém.

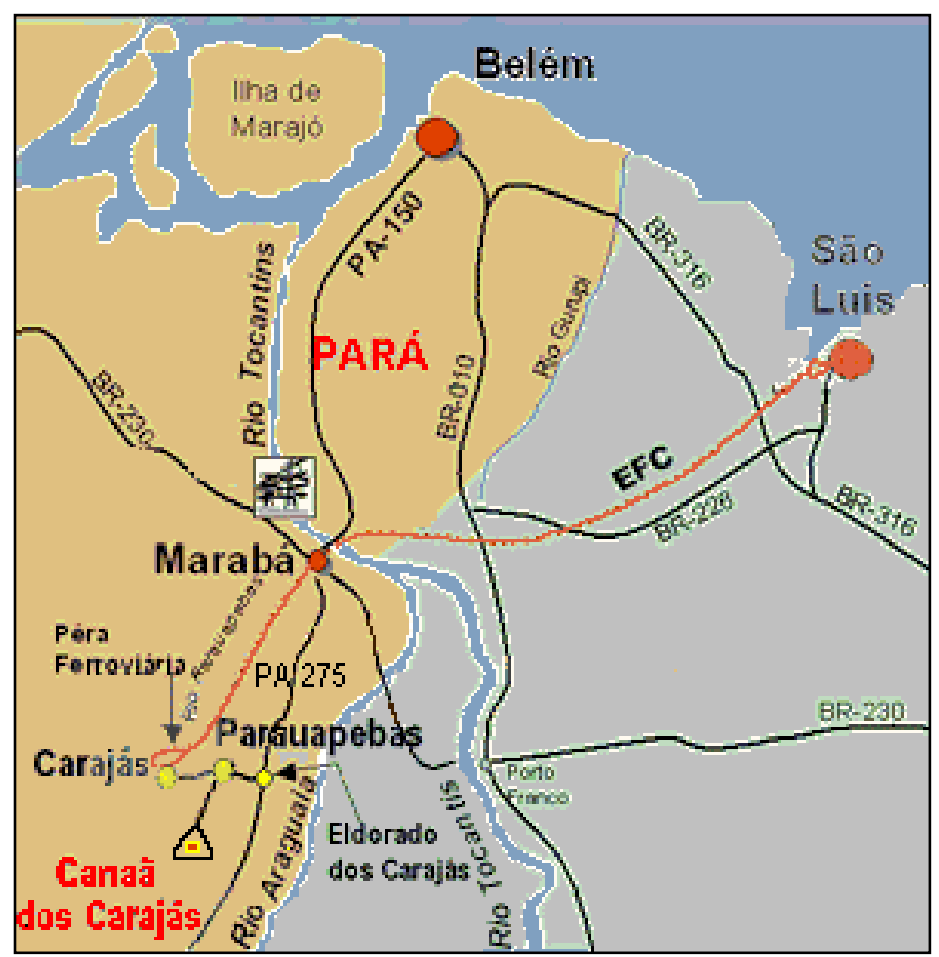

Figura 30 - Cidade de Canaã dos Carajás - PA

(Fonte: http://www.achetudoeregiao.com.br/pa/canaa_dos_carajas/dados_gerais.htm) 


\subsection{Etapa Prática}

A metodologia utilizada para avaliação do exemplo de caso da mina de Sossego dividida em: alinhamento inicial sobre a linha de pesquisa; diagnóstico do cenário operacional da mina de Sossego; formalização do procedimento atual de gestão operacional na mina de sossego; identificação dos principais KPI's operações; propostas de melhorias com base nos conceitos do PDCA 90-10; validação do modelo. Estes itens são detalhados a seguir.

\subsubsection{Alinhamento Inicial sobre a Linha de Pesquisa}

Neste caso, foram identificadas, por meio de reuniões com a equipe técnica do projeto, dentro do universo de operações da empresa, dois cenários operacionais distintos e possivelmente adequados aos objetivos do projeto de pesquisa: Unidade Sossego, com foco na exploração de cobre e o Complexo de Carajás, com a exploração de ferro. O critério principal para a escolha destas duas unidades foram as características de produção de cada uma, sendo Sossego um exemplo de produção voltada para a qualidade do produto, enquanto Carajás se caracteriza principalmente pelo volume de material movimentado.

Desta forma, conforme o avanço das discussões sobre o projeto, ficou definida a unidade de Sossego (Figura 31) como foco principal dos estudos a serem realizados.

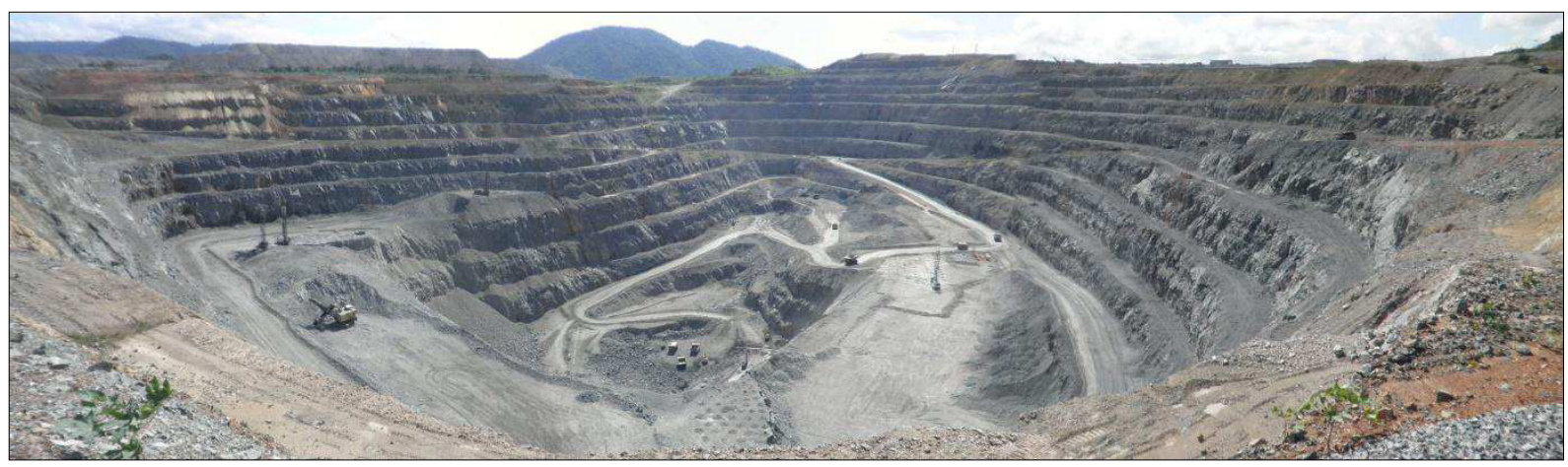

Figura 31 - Vista panorâmica de uma das cavas da unidade Sossego

(Fonte: Arquivo próprio) 


\subsubsection{Diagnóstico do Cenário Operacional da Mina de Sossego}

O Projeto Sossego foi o primeiro da empresa na exploração de cobre, tendo seu início ao ano de 2004 , com um teor médio de $29,7 \%$ de cobre e $7,5 \mathrm{~g} / \mathrm{t}$ de ouro. $O$ complexo de Sossego possui três cavas: Sossego, Sequeirinho e Pista. A exploração da jazida ocorre por meio de um sistema convencional de lavra, com escavadoras utilizadas na escavação e carregamento dos materiais e caminhões para o transporte. A mina de Sossego possui uma unidade de beneficiamento com capacidade nominal de $13 \mathrm{Mtpa}$, a qual consiste de um sistema de britagem primário, moagem, flotação e filtragem. O concentrado final da unidade de beneficiamento é transportado por caminhões rodoviários até a cidade de Parauapebas - PA e, a partir desta localidade, levado por trem até o porto de São Luís - MA, para ser finalmente exportado.

Devido ao cenário adverso particular da mina de Sossego, com alta variabilidade de teores no depósito, elevada relação estéril/minério e layout operacional reduzido (se comparado ao Complexo de Carajás, por exemplo), a empresa viu a necessidade de implementar um modelo de controle e gestão de mina que permitisse a avaliação das aderências de operação a curto prazo. Até então, os resultados das operações eram verificados em intervalos longos de tempo, o que gerava desvios relevantes de aderência, desvios estes que não podiam ser corrigidos em virtude das particularidades da mina.

Nesse cenário, entre os anos de 2005 e 2006, surgiram as ideias iniciais sobre um modelo de controle e gestão de mina que eliminasse a problemática dos gaps de comunicação existentes entre as áreas funcionais da mina e o planejamento e, além disso, que permitisse a avaliação contínua das operações realizadas. Foi então que foi implementado o modelo conhecido hoje como Line Up, que funciona como um fórum diário de discussões, do qual participam o responsável pelo Line Up, coordenadores de áreas e pessoal do planejamento. 


\subsubsection{Formalização do Procedimento Atual de Gestão Operacional na Mina de Sossego}

Com a implantação do Line Up para o controle e gestão das operações, na unidade Sossego, é realizada a medição do desempenho das áreas operacionais da mina utilizando dois índices básicos: o Índice de Aderência (IA) e o Índice de Comprimento (IC). O índice de aderência indica se um serviço estabelecido pelo Line Up foi executado ou não. O índice de comprimento quantifica o desvio de um serviço executado em relação ao que foi planejado. Neste caso, tanto o IA quanto o IC não definidos de acordo com notas padronizadas estabelecidas pela empresa.

As ferramentas de suporte utilizadas na reunião do Line Up são:

- GEMS 6.2: software de modelagem digital. A modelagem topográfica da mina é atualizada duas vezes por semana;

- VCN (intell i Mine): software (sistema da Modular) que compila as informações dos equipamentos (disponibilidade, manutenção, etc.);

- CIG (Centro de Informação Gerencial): sistema interno da empresa, (indicadores, paretos, performance);

- Sistema do Line Up: planilhas com as listas dos serviços e esquemas gráficos da localização dos equipamentos. Este sistema agrupa um banco de dados (gravação no excel) no qual é possível realizar consultas de acordo com as áreas, turnos, dentre outros.

A Figura 32 mostra a metodologia realizada pelo Line Up para o controle e gestão das operações de mina. 


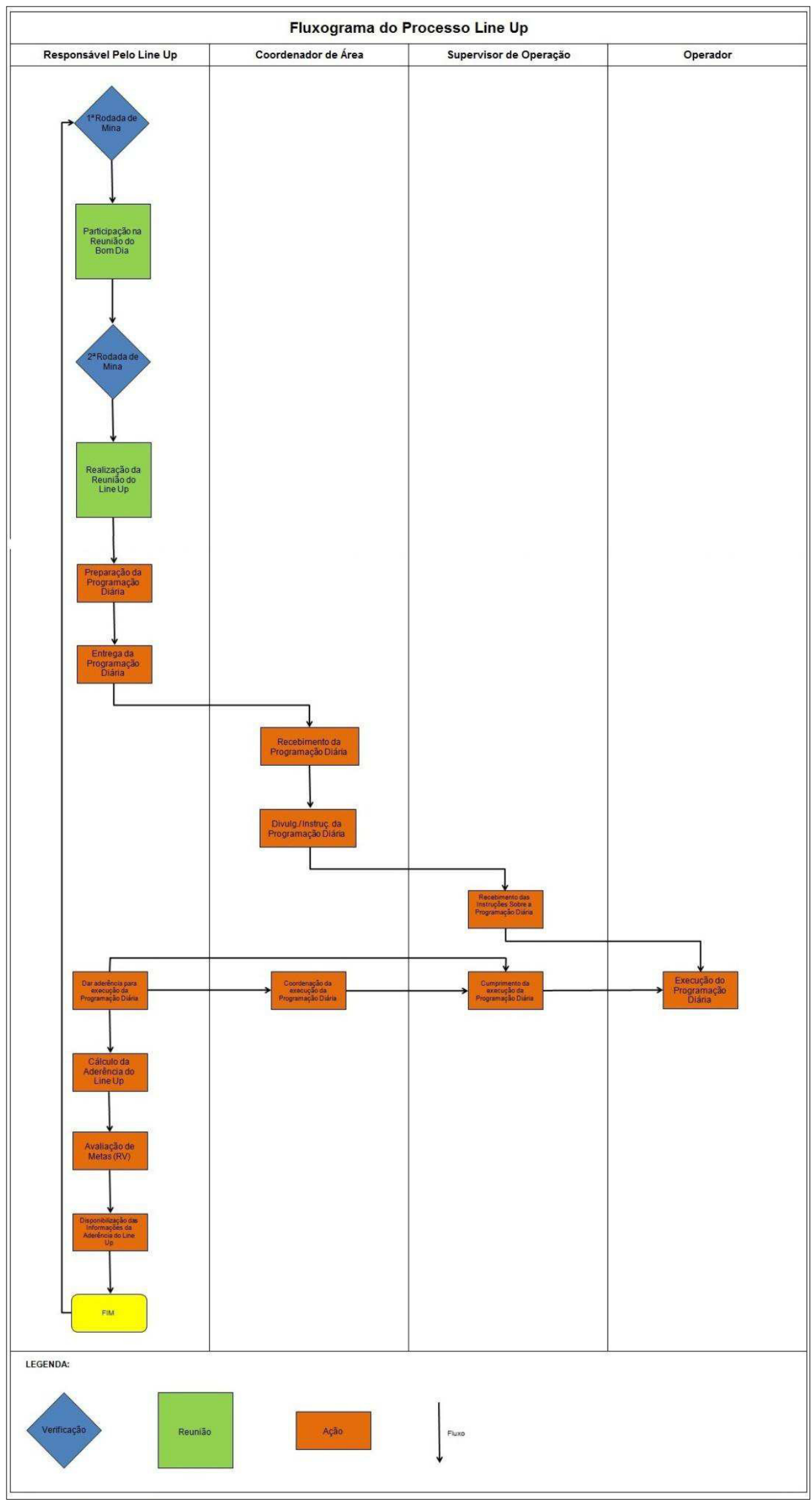

Figura 32 - Metodologia de execução do Line Up para o controle e gestão das operações (Fonte: Arquivo próprio) 
A primeira atividade diária do responsável pelo Line Up é a chamada rodada de mina, a qual consiste na observação geral da mina através dos mirantes panorâmicos existentes ao redor das cavas. Esta observação tem por objetivo dar uma visão macro do posicionamento dos equipamentos, áreas de desmontes programados para o dia, dentre outros. Em seguida, é realizada uma reunião inicial de alinhamento entre o responsável pelo Line Up e os coordenadores de áreas, onde são apresentados os status de todos os serviços listados para o turno anterior de operações e verificadas possíveis pendências.

Com o objetivo de confirmar os status dos serviços discutidos na reunião inicial de alinhamento, o responsável pelo Line Up, juntamente com os coordenadores de áreas, faz uma visita focal na mina, que é realizada cava a cava. Esta rodada de mina permite a verificação individual de cada atividade discutida e, além disso, permite a observação de novos serviços a serem adicionados ao Line Up do dia. Tendo em mente todo o cenário operacional do dia, o responsável pelo Line Up e os coordenadores de áreas retornam para o escritório da mina, onde será realizada a reunião do Line Up do dia, onde serão programados todos os serviços a serem executados.

Uma vez definidos os serviços a serem executados, de acordo com ordem de prioridade discutida ao longo da reunião, o responsável pelo Line Up armazena no SASP (Sistema de Aderência de Serviços e Produção) todas as informações geradas sobre as operações e, em seguida, prepara o plano de operações diário para cada coordenador de área. Após terem em posse os planos de operações gerados pelo responsável pelo Line Up, os coordenadores de áreas seguem para apresentar as informações aos supervisores de operação, os quais trabalham diretamente com os operadores.

A Figura 33 apresenta a estrutura hierárquica do Line Up. 


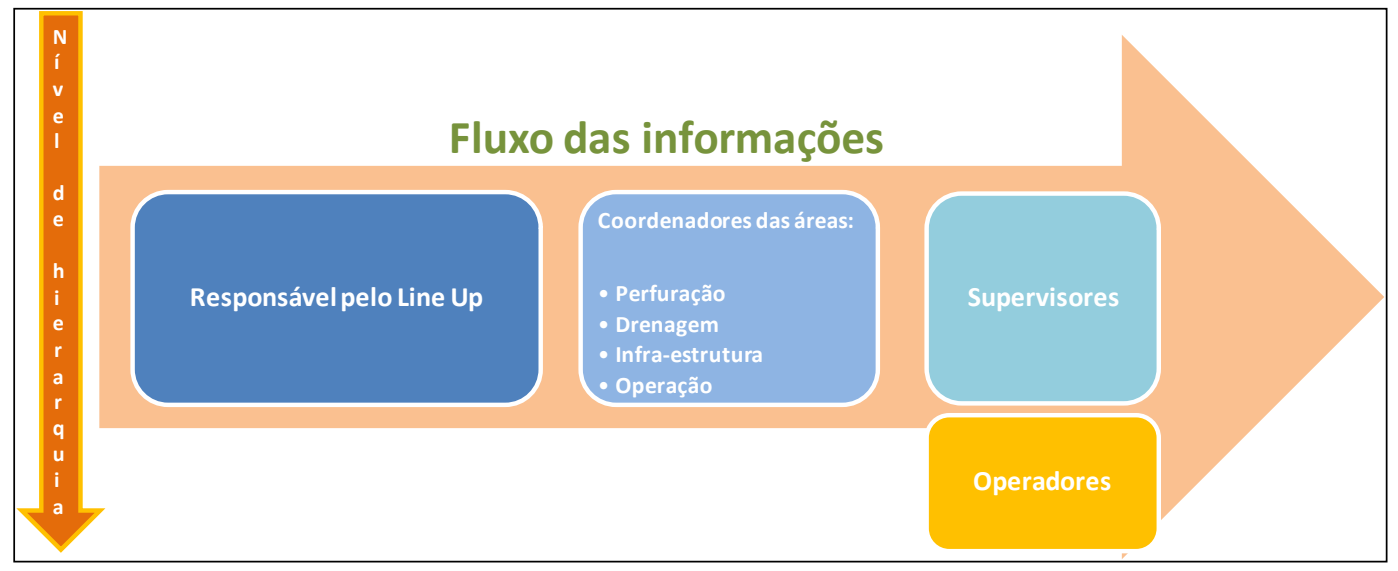

Figura 33 - Estrutura de hierarquia do Line Up

(Fonte: VALE)

A avaliação do desempenho das operações é realizada por meio do cálculo da aderência do Line Up, com a atualização das informações sobre as tarefas programadas. Nesta atualização de status, uma atividade poderá ser classificada em relação a dois índices: Índice de Aderência às Atividades Planejadas (IA) e Índice de Cumprimento Quantitativo Planejado (IC). Em relação ao IA, as atividades podem ser classificadas como aderentes, não-aderentes, não-conformes e sem status. $\mathrm{O}$ cálculo dos índices IA e IC e da aderência do Line Up são realizados conforme a seguir:

$$
\begin{aligned}
& I A=\frac{\text { Número de atividades aderentes }}{\text { Número total de atividades }} \\
& I C=\frac{\text { Total de serviços executados }}{\text { Total de serviços planejados }} \\
& \text { Aderência }(A)=\frac{I A+I C}{2}
\end{aligned}
$$

Onde,

$$
\begin{aligned}
& I A \rightarrow \text { Índice de Aderência às Atividades Planejadas } \\
& I C \rightarrow \text { Índice de Cumprimento Quantitativo Planejado }
\end{aligned}
$$

Uma vez calculada a aderência do Line Up, são geradas notas (ver Tabela 3 a seguir), que são utilizadas para medir o desempenho da operação. 
Tabela 3 : Indicadores de desempenho das operações por meio do cálculo da aderência do Line Up

\begin{tabular}{|c|c|c|c|c|c|c|}
\hline $\begin{array}{l}\text { Valores } \\
\text { calculados da } \\
\text { aderência }(A)\end{array}$ & $\begin{array}{l}0 \% \leq A \\
<83 \%\end{array}$ & $\begin{array}{l}83 \% \leq A \\
<85 \%\end{array}$ & $\begin{array}{l}85 \% \leq A \\
<88 \%\end{array}$ & $\begin{array}{l}88 \% \leq A \\
<90 \%\end{array}$ & $\begin{array}{l}90 \% \leq A \\
<94 \%\end{array}$ & $A \geq 94 \%$ \\
\hline $\begin{array}{c}\text { Nota de } \\
\text { desempenho } \\
\text { atribuída }\end{array}$ & 0 & 1 & 2 & 3 & 4 & 5 \\
\hline
\end{tabular}

(Fonte: Arquivo próprio)

\subsubsection{Identificação dos Principais KPI's das Operações}

Os principais KPl's utilizados na mina de Sossego para a programação das tarefas são, além da DF (Disponibilidade Física) e UF (Utilização Física), as próprias atividades a serem executadas (número de furos de desmonte, quantidade de produção, desmobilização de sistemas na mina, dentre outros), as quais são a base de cálculo dos índices de aderência (IA) e de cumprimento (IC). Durante a visita à mina de Sossego, um dos principais problemas apontados foi a disponibilidade física dos equipamentos de mina. Desta forma, com o objetivo do entendimento desse problema, foi realizada uma visita à unidade de manutenção de equipamentos da mina (Figura 34).

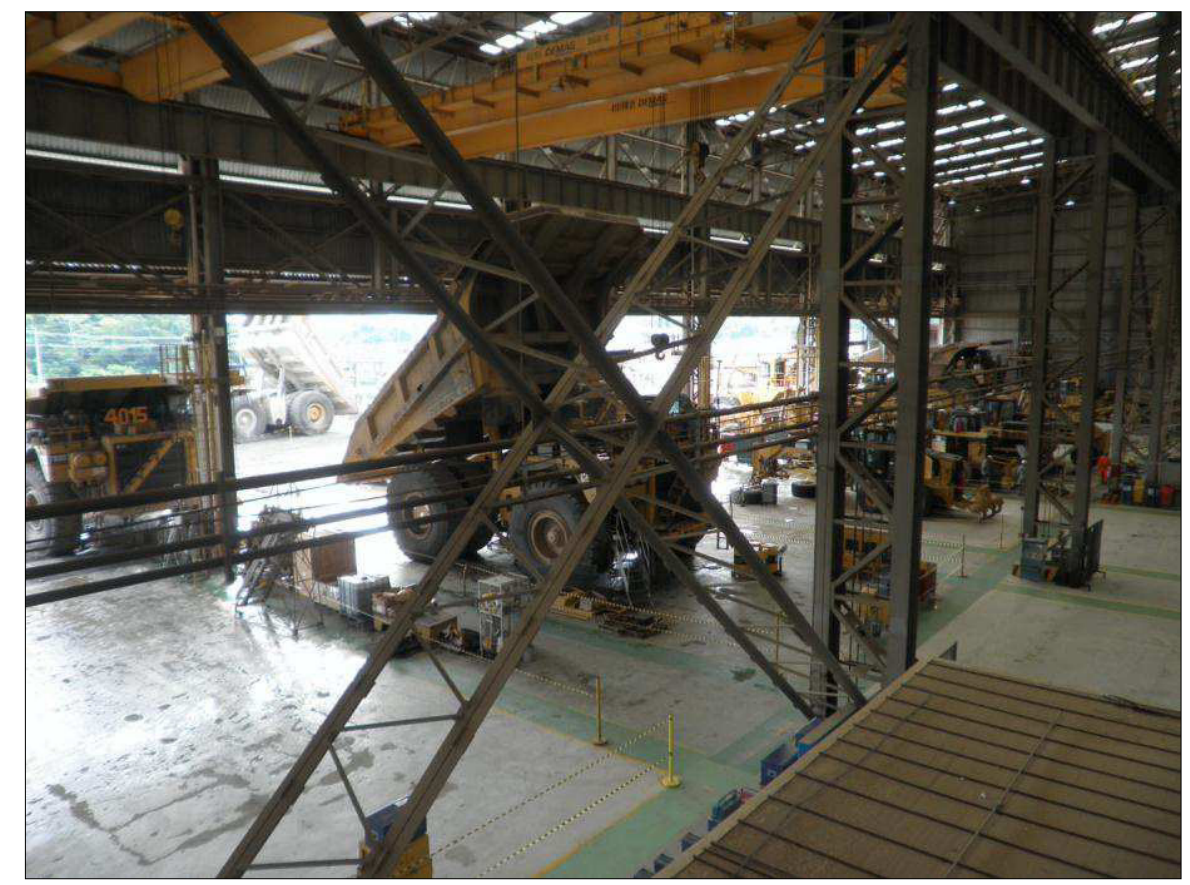

Figura 34 - Vista interna da unidade de manutenção de equipamentos da mina de Sossego (Fonte: Arquivo próprio) 
Segundo informações da empresa, um dos motivos para justificar a baixa DF apontada foi a primarização da equipe de manutenção. Neste caso de acordo com informações internas, em função da transição da manutenção, contratação de funcionários, aquisição de ferramentas e peças, os equipamentos ficaram de 3 a 4 meses sem manutenção preventiva (eram realizadas apenas as corretivas), o que gerou um passivo que está refletindo na DF atual, incluindo as suas áreas de planejamento e controle, que estavam sob controle de uma empresa terceirizada.

Mesmo com o processo de primarização, os serviços de manutenção mais complexos ainda serão realizados por empresas terceirizadas, segundo a empresa. Porém, os contratos serão estabelecidos com base nas horas trabalhadas. Com a primarização, a área de manutenção de equipamentos da mina de Sossego foi dividida em:

- Uma área que cuida de caminhões, equipamentos de carregamento e de infraestrutura (DIOC, GEOMY e GAMEY);

- Outra área que cuida dos conjuntos de perfuração, escavação e desmonte (GAYSY).

\section{Observação:}

A área de manutenção foi dividida em duas partes distintas de acordo com o porte dos equipamentos. Neste caso, equipamentos de menor porte e maior mobilidade (caminhões, carregadoras, dentre outros) são deslocados até a unidade de manutenção. No caso dos equipamentos de maior porte e/ou menor mobilidade (escavadoras de grande porte, perfuratrizes, etc.), a manutenção é realizada em campo.

\subsubsection{Propostas de Melhorias com Base nos Conceitos do PDCA 90-10}

Uma vez mapeada a metodologia de execução do Line Up, apresentada anteriormente, foram identificados diversos pontos de oportunidade para melhorias. 
Neste sentido, como principal resultado do trabalho de pesquisa, foi proposto à empresa o modelo PDCA 90-10, como forma de aprimorar o processo de controle operacional conhecido como Line Up, na mina de Sossego, tendo como objetivo principal melhorar o índice de aderência à programação das atividades. $O$ modelo aprimorado, proposto com base no PDCA 90-10, foi chamado de Line Up 90-10.

O Line Up 90-10 proposto é o resultado da incorporação dos conceitos base do PDCA 90-10 ao Line Up já existente na mina de Sossego, tendo como proposta solucionar os problemas identificados, de forma direcionada às áreas operacionais e táticas da mina de acordo com os princípios globais de governança da empresa. Isto representa na prática a integração de toda a cadeia de eventos que liga ações executadas, resultados dessas ações e as devidas responsabilidades a serem atribuídas 


\section{RESULTADOS}

O Line Up 90-10, conforme citado a priori, deverá ser o resultado da incorporação dos princípios e conceitos base do modelo PDCA 90-10. Portanto, sua funcionalidade exigirá disciplina para a posta em prática dos seguintes pontos:

- Racionalização do Processo de Lavra: todos os processos de lavra devem ser definidos, bem como seus respectivos responsáveis. Além disso, devem ser identificados todos os KPl's críticos para as operações. Uma vez que toda operação apresenta um conjunto de indicadores de desempenho (KPI's), os quais são utilizados para medir eficiência e qualidade das ações executadas, se faz necessária o estabelecimento de um banco de dados que seja acessível (de acordo com níveis de prioridade de acesso), transparente e auditável;

- Estruturação do Processo de Lavra: com o objetivo de melhor entender o processo de lavra, todas as operações devem ser expressas em forma de fluxogramas, onde possam ser identificados os KPI's críticos. Uma vez que o processo esteja devidamente estruturado, há a possibilidade, quando necessário, de serem realizados estudos de simulação para diferentes condições de trabalho, o que permite a avaliação dos resultados gerados por eventuais modificações nas condições de lavra;

- Reestruturação do Processo de Lavra: uma vez que sejam identificados pontos de melhoria com base, por exemplo, em simulações realizadas, o processo de lavra deverá ser reestruturado e os resultados observados devem ser acompanhados e avaliados, de forma que possam ser validados e, consequentemente, implementados em definitivo;

- Implementação de Melhorias: uma vez que as modificações identificadas como necessárias para uma operação (ou um conjunto de operações) sejam validadas, será necessário a elaboração de um plano de implementação prática de forma a causar os mínimos distúrbios possíveis. Isto é um fator crítico nas fases iniciais de implementação, nas quais é comum a 
necessidade de ajustes ou eventuais reformulações. Uma vez que estas melhorias seja implementadas, o cenário da lavra deverá ser acompanhado continuamente;

- Busca por Melhoria Contínua: o acompanhamento contínuo das operações em campo é um fator de grande relevância para o desempenho da lavra. Por se tratar de um ponto fundamental para a eficiência do processo de lavra como um todo, este tipo de atividade exigirá profissionais com habilidades de percepção, criatividade e bom senso. Aqui, podem ser observadas as duas principais características incorporadas do modelo PDCA 90-10: o grande esforço em campo ( $90 \%$ do trabalho) e a busca contínua por melhorias, de acordo com os princípios de um ciclo PDCA;

- Estabelecimento de Ordens de Hierarquia: sem que haja uma ordem de hierarquia bem definida, nenhum processo é controlável. No caso na mineração, esta afirmativa não é diferente. Para que o processo de lavra possa ser gerenciado de forma inteligente e eficiente, devem ser obedecidas ordens de hierarquias, as quais deverão ser definidas de acordo com o grau de complexidade do processo de lavra. Neste caso, independentemente do grau de complexidade do processo de lavra citado, há a necessidade de uma figura central de controle, a qual será responsável pela tomada final de decisões sobre o processo;

- Gestão Centralizada: para que o Line Up 90-10 funcione, será necessário que sua gestão ocorra de forma centralizada. Isto evitará que sejam quebradas as ordens de hierarquia preestabelecidas e que as ações planejadas sejam modificadas de forma não autorizada. Esta tarefa exigirá um profissional com grande capacidade de: negociação, tomada de decisões rápidas, visão analítica global do processo de lavra e, por fim, gerenciar níveis elevados de demanda de trabalho inerentes à função.

\section{Observação:}

A função de gerenciar o Line Up 90-10, conforme citado a priori, demandará um grande esforço pessoal por parte do profissional responsável por esta 
tarefa. Desta forma, recomenda-se que as empresas de mineração que busquem este tipo modelo para a gestão operacional de lavra implementem programas específicos de renovação para esta função. Sugere-se que o tempo de atividade do profissional nesta função não seja superior a 2 (dois) anos.

- Suporte de Tecnologia da Informação (TI): para que todas as informações geradas sobre o processo de lavra possam ser coletadas, utilizadas, transferidas e armazenadas em bancos de dados, há a necessidade de implementação de uma estrutura de TI robusta, segura, acessível (segundo critério de prioridade de acesso às informações) e rastreável. A não utilização de suporte de $\mathrm{TI}$ adequado poderá inviabilizar a implementação de modelos de gestão como o Line Up 90-10, por exemplo.

Uma vez que sejam devidamente realizados os pontos acima citados, o Line Up 9010 , bem como outros modelos que sigam as premissas indicadas, apresentará como resultados principais:

- Replicabilidade: o Line Up 90-10 poderá funcionar como um modelo replicável, com eventuais ajustes de acordo com variações de cenários operacionais, para outras minas a céu aberto. Esta característica se torna possível devido à incorporação dos conceitos base do PDCA 90-10, os quais podem ser direcionados a ajustados para diferentes especificidades operacionais das minas;

- Integração de Áreas Funcionais: a implementação do Line Up 90-10 solucionará a problemática da falta de comunicação entre as áreas funcionais da mina. Isto será possível devido a uma figura-chave: o responsável pela gestão e controle do modelo de gestão. Este profissional atuará como um elo de negociação entre todas as áreas da mina, ou seja, operação, planejamento, geologia, manutenção, dentre as demais. Desta forma, não existirão mais lacunas de comunicação, o que permitirá que os serviços sejam realizados de acordo com as premissas e prioridades mais relevantes; 
- Controle Total do Processo de Lavra: uma vez que se tenha à disposição informações confiáveis, profissionais capacitados e modelos de gestão adequados, o processo de lavra poderá ser gerenciado de forma racional, independentemente do nível de complexidade das atividades envolvidas.

A Figura 35 ilustra o Line Up 90-10, de acordo com suas premissas e resultados gerados.

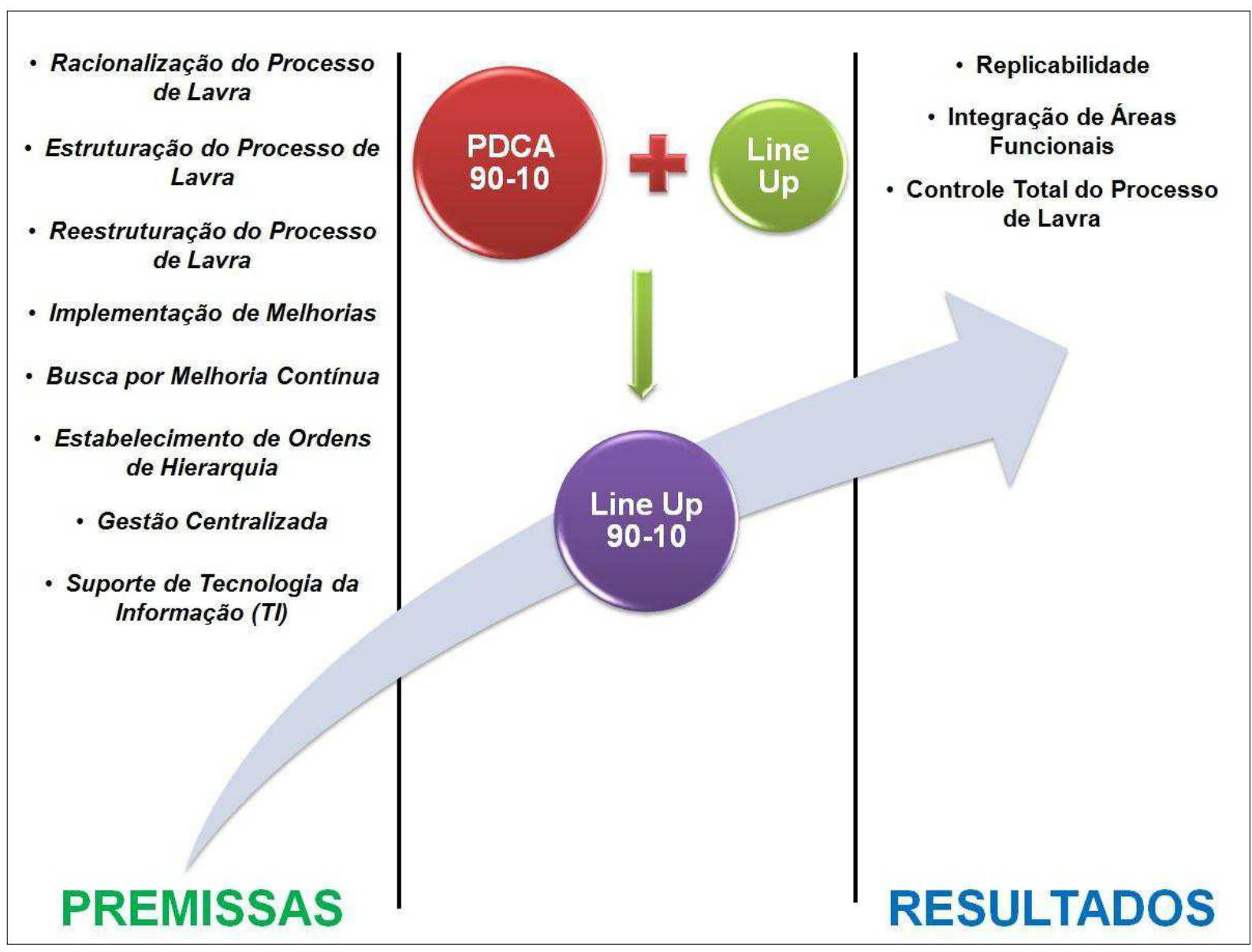

Figura 35 - Line Up 90-10, de acordo com suas premissas e resultados gerados (Fonte: Arquivo próprio)

A seguir, de acordo com pontos específicos de discussão, são apresentados os feedbacks da empresa parceira do projeto em relação ao modelo PDCA 90-10 apresentado: 


\section{Quebras de Hierarquia Observadas no Line Up:}

Segundo a empresa, às vezes isso pode ser útil, pois os supervisores buscam informações direto da fonte (Line Up). As informações passadas para os coordenadores e, subsequentemente, dos supervisores para os operadores pode acabar sendo confundidas;

Pontos questionados pela equipe da USP: (i) as informações são passadas corretamente e com clareza? (ii) há compreensão das partes envolvidas? (iii) as pessoas envolvidas são plenamente competentes para o exercício de suas funções?

\section{Atividades do Line Up:}

As atividades são definidas e atualizadas no Sistema Line Up. Cada atividade a ser realizada é discutida em comum acordo entre todas as áreas, de acordo com ordem de prioridade de serviços.

\section{Treinamento de Operadores:}

A questão do treinamento de operadores, para a criação de uma cultura de entendimento e responsabilidade em relação à suas ações, já havia sido levantada pelo próprio processo Line Up. Entretanto, segundo a empresa, ainda não é possível fazer tal tipo de treinamento com todos os operadores. Neste caso, a empresa justificou que está fazendo isso com os técnicos, os quais auxiliam diretamente os supervisores. Como o supervisor muitas vezes não tem como desprender todo tempo na mina, cabe ao técnico orientar os operadores.

Ponto de melhoria identificado pela equipe USP: esses técnicos poderia atuar como disseminadores de conhecimento entre os operadores. Os supervisores sabem o que fazer e têm as informações necessárias, mas às vezes não estão em campo. Logo, os técnicos poderiam agir nesses momentos. 


\section{O Modelo Hierárquico do Line Up:}

Foi observada uma ineficiência no modelo hierárquico (horizontal) do Line Up. A equipe da USP apresentou como proposta de melhoria um modelo hierárquico vertical. A empresa justificou que isso seria uma situação ideal, porém, não seria possível no caso estudado.

\section{Mudanças Observadas no Line UP:}

Foram implementados recursos de informática que reduziram o esforço na condução do Line Up. Neste sentido, foi implementado o Sistema Line Up, o qual está plenamente integrado ao sistema de despacho da mina. $O$ cálculo da aderência do Line Up também sofreu mudanças. Porém, até o momento, estas mudanças não foram apresentadas à equipe da USP.

\section{Integração Entre Áreas:}

Sobre o envolvimento direto das áreas de manutenção e da usina de beneficiamento no Line Up sugeridas pela equipe do projeto, a empresa justificou que isso não agregaria tanto valor. Segundo a empresa, essa integração já existe informalmente, uma vez que o responsável pelo Line Up já atua como uma ligação direta com essas outras áreas. Segundo a empresa, a participação dessas áreas nas reuniões de Line Up apenas as deixaria ociosas durante as reuniões.

7. Line Up na Mina: todos entendem que é importante trazer soluções que levem o Line Up a estar mais tempo presente na mina. Entretanto, o que a equipe da USP observou foi que o responsável pelo Line Up ocupa a maior parte de seu tempo em atividades de escritório (grande carga de reuniões). O responsável pelo Line Up, segundo a VALE, trabalha $60 \%$ de seu tempo em escritório e $40 \%$ campo;

\section{Funções de trabalho:}

Até o momento, não ficou definida claramente a figura (função) do coordenador. Esta função existe informalmente dentro da empresa. Nesta questão, a empresa justificou:

(i) criar um novo cargo para a função de coordenador seria difícil, mesmo 
reconhecendo que, desta forma, a hierarquia vertical sugerida pela equipe da USP poderia funcionar na prática; (ii) a empresa reconhece que, no formato como está hoje, existem problemas de subordinação entre as áreas funcionais da mina, ou seja, há situações onde os supervisores só aceitam responsabilidades passadas diretamente por seus gerentes de área. Neste caso, o responsável pelo Line Up precisa informar um problema ao seu gerente (gerente de curto prazo), de forma que este gerente entre em contato com o gerente da área a qual apresenta pendência para que sejam dadas as diretrizes a serem cumpridas.

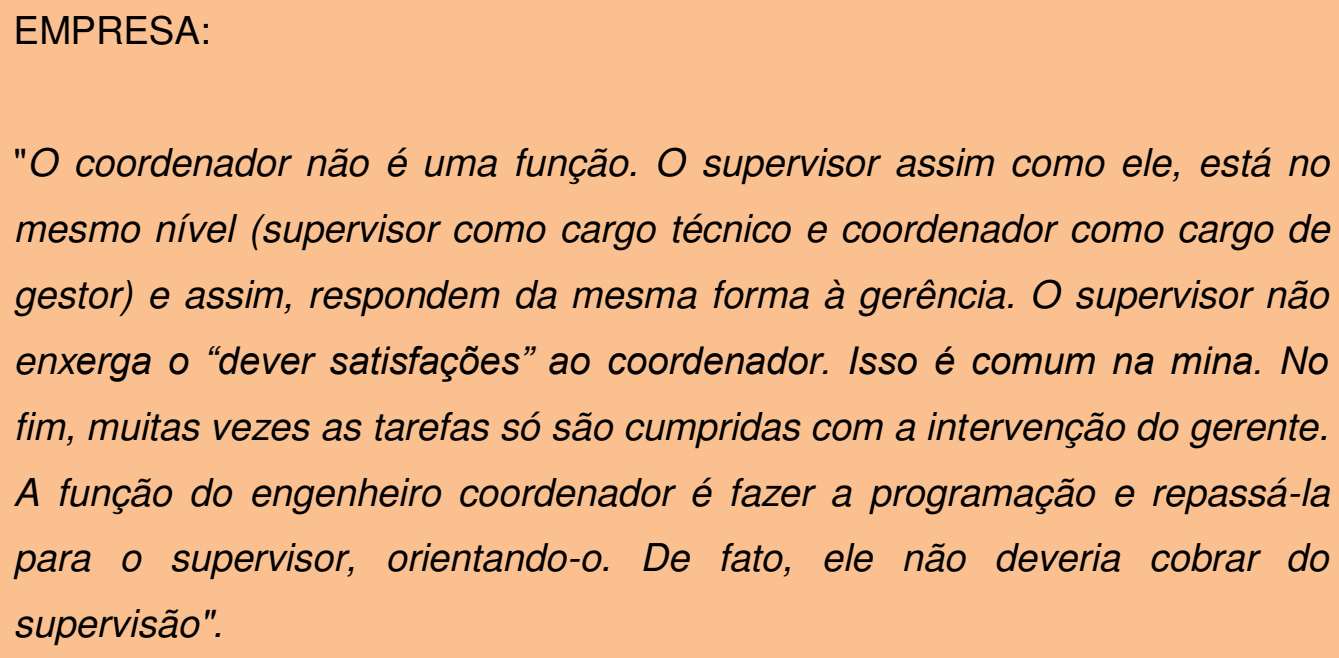
mesmo nível (supervisor como cargo técnico e coordenador como cargo de gestor) e assim, respondem da mesma forma à gerência. O supervisor não enxerga o "dever satisfações" ao coordenador. Isso é comum na mina. No fim, muitas vezes as tarefas só são cumpridas com a intervenção do gerente. A função do engenheiro coordenador é fazer a programação e repassá-la para o supervisor, orientando-o. De fato, ele não deveria cobrar do supervisão".

\section{Pontos de melhoria identificado pela equipe USP para esta situação: formalizar} o cargo do coordenador, de forma a permitir que seja posto em prática o modelo hierárquico vertical sugerido pela equipa USP. Além disso, seria fundamental um acompanhamento dos trabalhos fora do horário administrativo, pois são perdidas informações entre os coordenadores e os supervisores nesses horários de trabalho.

\section{Observações:}

(i) A empresa acha que uma possível solução para essa problemática seria a utilização de 2 (dois) responsáveis pelo Line Up, o que eliminaria a função do coordenador. Neste caso, segundo a empresa, um Line Up seria focado mais nas reuniões e planos e outro na cobrança em campo.

(ii) A equipe do projeto observou que, mesmo se tratando de um processo, 0 Line Up é visto internamente como a figura de uma pessoa. A equipe da USP 
sugeriu que esta visão deveria ser modificada no ambiente da empresa. Porém, a empresa justificou que isso seria algo praticamente impossível de ocorrer. 


\section{CONCLUSÕES}

Em relação aos objetivos apresentados inicialmente para este trabalho de pesquisa, as conclusões são:

- Foi realizado um estudo dos aspectos referentes à gestão de minas a céu aberto, com ênfase na gestão das operações e dos equipamentos de lavra. Este estudo permitiu identificar os pontos de maior relevância para uma gestão racional de minas a céu aberto;

- Foram definidos os conceitos de um modelo conceitual para a gestão de ativos de minas a céu aberto, o PDCA 90-10, o qual funciona como uma ferramenta direcionada para as áreas operacionais e táticas da mineração, com a finalidade de coordenar as atividades das equipes de operação de forma alinhada aos objetivos globais das empresas;

- O modelo conceitual PDCA 90-10 foi apresentado para a gerência da mina onde foram realizados os estudos, com o objetivo de que seus conceitos base fossem incorporados ao modelo de gestão já existente, com o objetivo do seu aprimoramento para a solução dos desafios da integração entre as áreas de planejamento e operação.

- O foco deste trabalho foram as operações de minas a céu aberto. Porém, como continuidade da pesquisa, recomenda-se estudos similares relativos a operações subterrâneas. 


\section{REFERÊNCIAS BIBLIOGRÁFICAS}

ALBANESE, T. Rio Tinto chief executive unveils vision for mine of the future. In: RIO TINTO WEBSITE. Press Release 2008. Disponível em: $<$ http://www.riotinto.com/documents $>$. Acesso em: 15 out. 2011.

BACON, F., UTAH, D. Technology of auger mining. Springfield, VA: National Technical Information Center, 1975. 78 p. Report PB259316.

BLAKELY, J. W. New triple-head auger proves its worth in low-seam coals. Coal Mining and Processing, Chicago, v. 12, n. 10, p. 66-67, 1975.

BUCYRUS-ERIE COMPANY. Mining supervisory training program. South Milwaukee, WI, 1976. p. $1.1-5.13$.

CAMPOS, V. FALCONI, Gerenciamento da Rotina do Trabalho do Dia a Dia. $6^{\text {a }}$ ed., Belo Horizonte, Editora de Desenvolvimento Gerencial, 1994.

CAMPOS, V. FALCONI, TQC - Controle da Qualidade Total (no estilo japonês).Fundação Cristiano Otoni/Escola de Engenharia da Universidade Federal de Minas Gerais. Belo Horizonte. 1992.

CATERPILLAR. Perspectives on modern mining. Revista Viewpoint 2008. $3^{\text {a }}$ edição. Disponível em: <https://mining.cat.com/viewpoint>. Acesso em: $11 \mathrm{dez}$. 2012.

CEMA BULK BELT CONVEYOR AND ACCESSORIES MANUFACTURING MEMBERS. Belt conveyors for bulk materials. $5^{\text {th }}$ ed. Naples: Conveyor Equipment Manufacturers Association, 1997. 430 p.

CHADWICK, J. Highwall mining. Mining Magazine, London, v. 169, p. 347-353, Dec. 1993. 
COPANS, G. Feasibility study explores in-pit crushing for Grootegeluk mine. In: Mining Weekly. Edition of $11^{\text {th }}$ May 2007. Disponível em: $<$ http://www.miningweekly.com/article/feasibility-study-explores-inpit-crushing-forgrootegeluk-mine-2007-05-11>. Acesso em: 15 out. 2011.

CRAWFORD, J. T.; HUSTRULID, W. A. (Ed.). Open pit mine planning and design. New York: SME-AIME, 1979. 367 p.

FULGENCIO, P. C. Glossário Vade Mecum: administração pública, ciências contábeis, direito, economia, meio ambiente. Rio de Janeiro: Mauad Editora, 2007. $64 \mathrm{p}$.

GODOY, A. L. Tutorial: ciclo PDCA. Disponível em: <http://www.cedet.com.br>. Acesso em: 21 jan. 2013.

HARTMAN, H. L.; MUTMANSKY, J. M. Introductory mining engineering. $2^{\text {nd }}$ ed. Hoboken, N. J.: John Wiley, 2002. 570 p.

HARTMAN, H. SME Mining Engineering Handbook. $2^{\underline{a}}$ edição, Society for Mining, Metallurgy and Exploration. In: In pit crushing and conveying. Inc. Colorado: Earl M. Frizzel and Thomas W. Martin, 1992. 2260p. cap 13.5, p. 1343-1351. 18p.

HUSTRULID, W. A.; KUCHTA, M. Open pit mine planning \& design. Rotterdam: Balkema, 1995. v. 1

ISHIKAWA, K., Introduction to Quality Control, 3A Corporation. Tokyo. 1989.

ISHIKAWA, K., Controle de Qualidade Total: à maneira japonesa. Editora Campos, Rio de Janeiro, 1993.

JAMASMIE, C. Lonely trucks in a lonely place: autonomous trucks debut in Chile's desert. In: Mining.com Magazine, v. 2, n. 2, p. 23-24, April 2009. Disponível em: $<$ http://magazine.mining.com/Issues/0904/KomatsuAutonomousTrucksDebutChileDe sert.pdf>. Acesso em: 18 out. 2011. 
JAMASMIE, C. The mine of the future might be a thing of the past. In: MINING.com. Jan. 2010. Disponível em: <http://www.mining.com/the-mine-of-the-future-might-bea-thing-of-the-past/>. Acesso em: 21 out. 2011.

KAHLE, M. B.; MOSELEY, C. A. Development of mining methods is Gulf coast lignites. Mining Engineering, v. 35, n. 8, p. 1163-1166, Aug. 1983.

LEHTINEEN, H. Cost comparison of loading, crushing and haulage methods in open pits quarries. Toukokuu: [s.n.], 1989. 93 p.

LOPES, J. R. Viabilização técnica e econômica da lavra contínua de minério de ferro com o sistema de britagem móvel inpit auto-propelido. 2010. 90 p. Dissertação (Mestrado) - Universidade Federal de Ouro Preto, Ouro Preto, 2010.

MARCCELLI, R. P. O papel dos indicadores de desempenho na estratégia das organizações para o aprimoramento de processos: um estudo de caso. 2000. Dissertação (Mestrado) - Universidade Federal de Santa Catarina, Florianópolis, 2000.

MARTINS, G. Princípios de automação industrial. Santa Maria, RS: Universidade Federal de Santa Maria. Centro de Tecnologia. Departamento de Eletromecânica de Potência, 2007. 215 p.

$\mathrm{MEECH}$, J. Autonomous haulage trucks. Vancouver: University of British Columbia, 2008. (Engineering case Studies. Case study 4: Sustainable mining. Part III: Automation in Mining).

MORAES, C.; CASTRUCCI, P. Engenharia de automação industrial. Rio de Janeiro: Editora LTC, 2001.

MORRISON, R. G. K.; RUSSEL, P. L. Selecting a mining method: rock mechanics, other factors. In: CUMMINGS, A.B.; GIVENS, I.A. (Ed.). SME mining engineering handbook. New York: Society of Mining Engineers, American Institute of Mining, Metallurgical, and Petroleum Engineers, 1973. v. 1, sec. 9, p. 9-1/9-22. 
NADER, B.; SACHS, P. F. T. Sistemas de gestão da produção e a cadeia de valor mineral. Brasil Mining Site, 03 mar. 2008. Disponível em: $<$ http://www.brasilminingsite.com.br/includes/modulos/mdl artigo/exibir artigo.php?id $=33$ >. Acesso em: 21 out. 2011.

NEBOT, E. Surface mining: main research issues for autonomous operations. Sydney: CRC Mining University of Sydney. Australian Centre for Field Robotics, 2005. $13 \mathrm{p}$.

PFLEIDER, E. P. Open-pit and strip-mining systems and equipment. In: CUMMINGS, A.B.; GIVENS, I.A. (Ed.). SME mining engineering handbook. New York: Society of Mining Engineers, American Institute of Mining, Metallurgical, and Petroleum Engineers, 1973. v. 2, sec. 17, p. 17-1/17-180.

PELTOMAKI, M. The application of self-propeled in underground mining. 1991. 82 p. Tese (Doutorado) - Faculty of Process Engineering and Material Science. Helsink University of Technology, Otaniemi, 1991.

POWER, W. R. Construction materials: dimension and cut stone. In: LEFOND, S. J. (Ed.). Industrial minerals and rocks. $4^{\text {th }}$ ed. New York: SME-AIME, 1975. p. 157174.

ROSÁRIO, J. Princípios de mecatrônica. São Paulo: Pearson Prentice Hall, 2005. $356 \mathrm{p}$.

SACHS, P. F. T. Cadeia de valor mineral e tecnologia da informação: alinhamento estratégico como gerador de eficácia em empresas de mineração. 2009. 169 p. Tese (Doutorado) - Escola Politécnica, Universidade de São Paulo, São Paulo, 2009.

SCHEDING, S.; NEBOT, E.; DURRANT-WHYTE, H. High integrity navigation using frequency domain techniques. IEEE Transactions of System Control Technology, v. 8, n. 4, p. 676-694, July 2000. 
SILVA, V. Curso de carregamento e transporte de rochas. Mariana: Samarco Mineração S/A, 1994. 52 p.

TASSINARI, C. C. G.; MELLITO, K. M.; BABINSKY, M. Age and origin of the Cu (Au-Mo-Ag) Salobo 3A ore deposit, Carajás mineral province, Amazonian craton, northern Brazil. São Paulo: Centro de Pesquisas Geocronólogicas. Instituto de Geociências, Universidade de São Paulo, março de 2003.

TRUEMAN, E. In-pit crushing: the application and benefits of track mounted crushing equipment. In: ANNUAL GENERAL MEETING OF THE INSTITUTE OF QUARRYING - SOUTH AFRICA, 28 ${ }^{\mathrm{TH}}, 1997$, Durban, South Africa. Proceedings. Walkerville, South Africa: Institute Quarrying - South Africa, 1997. p. 77-92.

VELOSO, N. Gerenciamento e manutenção de equipamentos móveis. São Paulo: Sobratema, 2009. 284 p.

WERKEMA, MARIA CRISTINA C., Ferramentas Estatísticas Básicas para o Gerenciamento de Processos. 1a ed., Belo Horizonte, Fundação Cristiano Otoni, Escola de Engenharia da UFMG, 1995b.

WHITTLE, G. Global asset optimisation. In: INTERNATIONAL SYMPOSIUM ON OREBODY MODELLING AND STRATEGIC MINE PLANNING, 2004, Perth, Australia. Uncertainty and risk management models: proceedings. Carlton: Australasian Institute of Mining and Metallurgy, 2005. p. 305-310. (AusIMM Spectrum Series, n. 14).

ZIMMERMANN, E.; KRUSE, W. Mobile crushing and conveying in quarries: a chance for better and cheaper production. In: INTERNATIONAL SYMPOSIUM CONTINUOUS SURFACE MINING, $8^{\text {TH }}, 2006$, Aachen. ISCSM 2006: proceedings. Aachen: Mainz, 2006. 7 p.

ZOSCHKE, L. T. Recent experiences with autonomous trucks in open pit mines. In: WESTERN MINING ELECTRICAL ASSOCIATION MEETING, Nov. 2002, Denver, 
CO. Proceedings. Disponível em: <http://www.wmea.net.pdf>. Acesso em: 26 out. 2011. 